\title{
Taxonómiai és filogenetikai vizsgálatok a palearktikumi Saphonecrus Dalla Torre \& Kieffer tölgy gubacs inquilin fajokon (Hymenoptera: Cynipidae, Synergini)
}

\author{
Ph.D. értekezés
}

Bozsó Miklós

SZTE TTIK Környezettudományi Doktori Iskola

2015

Szeged

Témavezető: Dr. Melika George Belső konzulens: Dr. Pénzes Zsolt 


\section{Tartalomjegyzék}

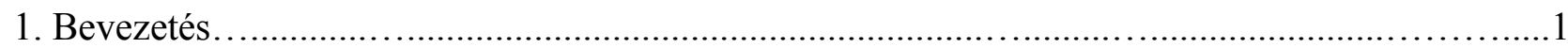

1.1. A Cynipidae család és Cynipinae alcsalád jellemzése...................................................1

1.2. A Synergini Ashmead, 1896 tribus jellegzetességei: a társbérlő (inquilin) életforma.....2

1.3. Morfológia.......................................................................................... 4

1.4. A Synergini tribus fajainak földrajzi elterjedése....................................... 7

1.5. A tölgyféléken élő cynipid inquilinek gazdanövény kapcsolatai................................11

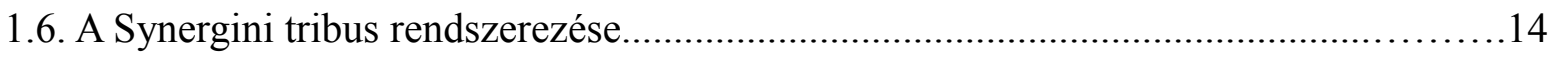

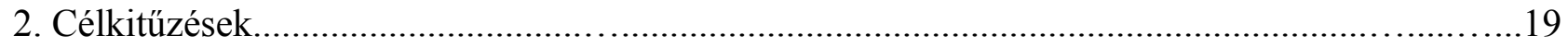

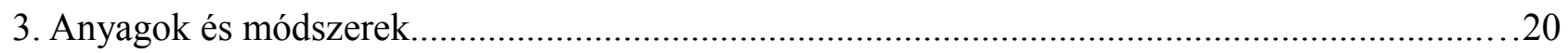

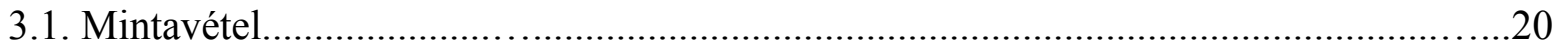

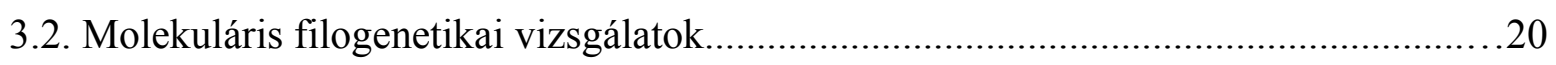

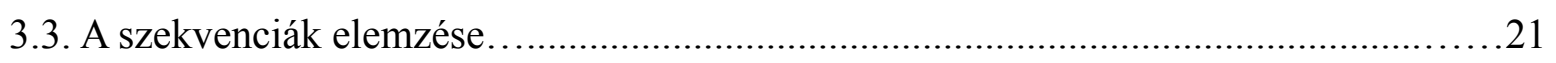

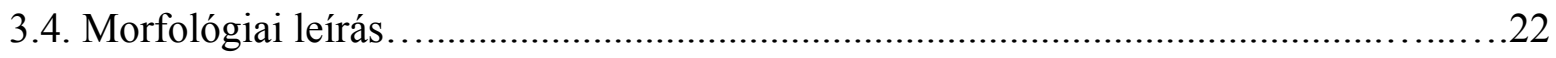

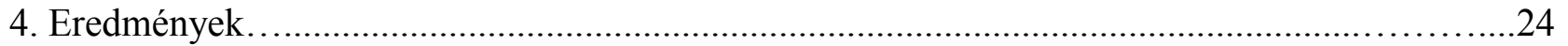

4.1. A molekuláris filogenetikai és morfológiai elemzések kombinált eredményei...........24

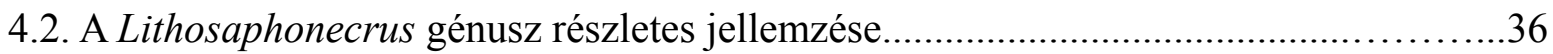

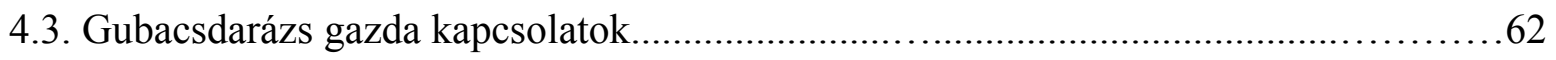

4.4. Gazdanövény kapcsolatok................................................................. 70

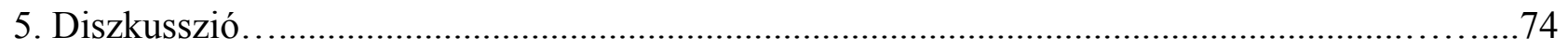

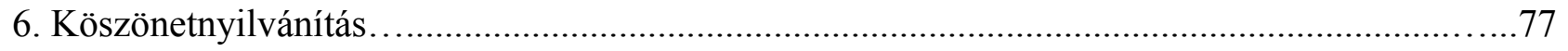

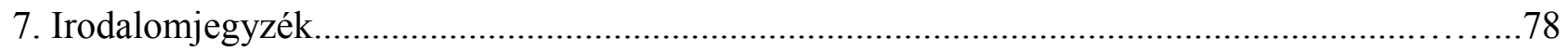

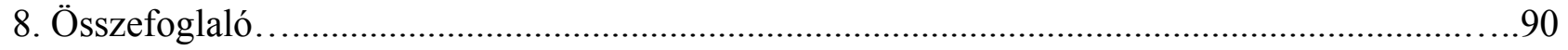

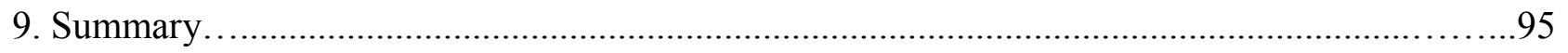

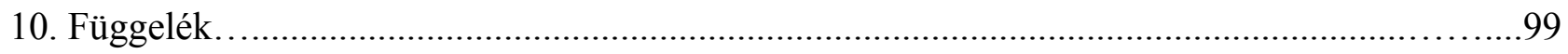




\section{Bevezetés}

\subsection{A Cynipidae család és Cynipinae alcsalád jellemzése}

A növényi gubacsok olyan rendellenesen módosult növényi szövetek amelyek kialakulásában az organizmusok változatos köre (vírusok, baktériumok, gombák, fonálférgek, atkák és rovarok) vehet részt (Espirito-Santo és Fernandes 2007, Raman és mtsi 2009). Kapcsolatuk a gubacsképző számára egyoldalúan előnyösnek tünik (kommenzalizmus) habár napjainkig kevés vizsgálatot végeztek annak tesztelésére, hogy a fajok között fennálló fenti kapcsolat a gazdanövény számára jelent-e bármilyen előnyt (Stone és Schönrogge 2003, Rocha és mtsi 2013). A gubacsképződés az állat-növény kölcsönhatás egyik leglátványosabb formája, amely a rovarok körében is több alkalommal megjelent az evolúció során (Espirito-Santo és Fernandes 2007). A gubacs képződését jelentősebb mértékben a rovar szabályozza, ennek mechanizmusa azonban kevésbé ismert (Stone és Schönrogge 2003, Kumashiro és mtsi 2011, Yamaguchi és mtsi 2012, Tokuda és mtsi 2013, Fujii és mtsi 2014). A gubacs biztonságos élőhely az abban fejlődő lárva számára mivel a gazdanövény által biztosított mikrokörnyezetben védelmet élvez az időjárás hatásaival és a ragadozókkal szemben, valamint a gubacs speciális táplálószövete megfelelő tápanyagforrást jelent növekedése alatt. Szerkezeti felépítése, helye (növényi szerv: ág, szár, levél, barka stb.) és a gubacsképződés ideje változatos (Stone és mtsi 2002). Összetett struktúrájának adaptív természete jelenleg szintén nyitott kérdés (Stone \& Schönrogge 2003). Gyakran rendkívül bonyolult megjelenésüknek köszönhetően a gubacsképző fajokat a kifejlett egyedek hiányában is be lehet általuk azonosítani. Ez különösen érvényes a rovarok és atkák által indukált gubacsok esetében.

A Cynipidae család a Hártyásszárnyúak (Hymenoptera) rendjén belül a Cynipoidea családsorozatba tartozik, amely hozzávetőleg 3000 leírt fajt tartalmaz (Fergusson 1995, Ronquist 1999). A Cynipidae család és egy Figitidae családon belüli inquilin génusz kivételével a családsorozatba tartozó valamennyi cynipoid darázs parazitoid életmódot folytat és valószínüleg a cynipid gubacsdarazsak is egy parazitoid ősből fejlődtek ki (Ronquist 1995, 1999). Jelenleg kb. 1400 cynipid gubacsdarázs fajt ismerünk (Liljeblad és Ronquist 1998, Ronquist 1999, Ronquist és Liljeblad 2001, Nieves-Aldrey 2001, Melika 2006), bár Nordlander (1984) becslése szerint a tényleges szám 3000 és 6000 között lehet.

Történelmi okokból minden jelenleg élö gubacsdarázs faj a Cynipinae alcsaládba tartozik és két fő trófikus csoportra bontják fel őket: gubacsképzőkre és a gubacshoz kötődő társbérlőkre (inquilinek). Ezek együttesen 8 tribust alkotnak (Csóka és mtsi 2005, Liljeblad és mtsi 2011) (1. 
táblázat). Ezeket főként a biológiai tulajdonságaik, tápnövény specifitásuk és morfológiai jellemzőik alapján különítik el egymástól.

\begin{tabular}{|c|c|c|c|c|}
\hline Tribus & Fajs zám & Éle tmód & Gazdanövény & $\begin{array}{c}\text { Fó elte rje dési } \\
\text { te rület }\end{array}$ \\
\hline Synergini & 186 & $\begin{array}{c}\text { Főleg a Cynipidae család } \\
\text { tagjainak inquilinjei } \\
\text { (társ bérlői) }\end{array}$ & Fásszárú rózs afélék & Holarktikus \\
\hline Aylacini & 157 & Gubacs képzők & $\begin{array}{c}\text { Rubus nemzetség (Ros aceae) fajai } \\
\text { és lágyszárú növények }\end{array}$ & Holarktikus \\
\hline Diplolepidini & 58 & Gubacs képzők & Rosa nemzetség (Ros aceae) fajai & Holarktikus \\
\hline Eschatocerini & 3 & Gubacs képzők & $\begin{array}{l}\text { Acacia nemzetség és Pros opis } \\
\text { nemzetség (Fabaceae) fajai }\end{array}$ & Neotropikus \\
\hline Qwaqwaiini & 1 & Gubacs képzők & $\begin{array}{c}\text { Scolopia nemzetség (Salicaceae) } \\
\text { fajai }\end{array}$ & Afrotropikus \\
\hline Pediaspidini & 2 & Gubacs képzők & $\begin{array}{c}\text { Acer nemzetség (Sapindaceae) } \\
\text { fajai }\end{array}$ & Palearktikus \\
\hline Paraulacini & 6 & $\begin{array}{c}\text { Aditrochus rend } \\
\text { (Pteromalidae) tagjainak } \\
\text { parazitoidjai vagy } \\
\text { inquilinjei (társ bérlői) }\end{array}$ & $\begin{array}{l}\text { Nothofagus nemzetség } \\
\text { (Nothofagaceae) fajai }\end{array}$ & Neotropikus \\
\hline Cynipini & 936 & Gubacs képzők & $\begin{array}{l}\text { Fagaceae cs alád tagjai (fóként a } \\
\text { Quercus nemzetség fajai) }\end{array}$ & Holarktikus \\
\hline
\end{tabular}

1. táblázat A Cynipinae alcsalád törzsei Liljeblad és mtsi (2011) nyomán.

A Synergini tribus tagjai (186 faj) mind inquilinek egyéb cynipid gubacsdarazsak gubacsaiban (Nylander 2004a, Liljeblad és mtsi 2008, Liljeblad és mtsi 2011, Pénzes és mtsi 2012). Annak ellenére, hogy fitofágok és képesek előidézni más gubacsdarazsak gubacsain belül az őket tápláló szövetek kifejlődését, nyilvánvalóan nem képesek önállóan saját gubacs fejlődését elindítani a gazdanövényen (Brooks és Shorthouse 1988). Ezért az alcsaládon belül a gubacsképző cynipid darazsak és a cynipid inquilinek közt nem csupán morfológiai hanem egyértelmü biológiai különbségek is felfedezhetőek.

A Synergini tribus-ról számos értékelő cikk született az elmúlt évtizedben azonban ezek mindegyike vagy csak a törzs morfo-taxonómiai vagy filogenetikai elemzésére korlátozódott (Nieves -Aldrey 2001, Pujade-Villar és mtsi 2003, Csóka és mtsi 2005, Sadeghi és mtsi 2006, Pénzes és mtsi 2009, Ács és mtsi 2010, Melika és mtsi 2012). Különösen sok új génuszt és fajt írtak le a Synergini tribus-ban a Kelet-Palearktikus, Orientális és Neotrópusi régióból.

\subsection{A Synergini Ashmead, 1896 tribus jellegzetességei: a társbérlő (inquilin) életforma}

Az inquilin kifejezés a latin “inquilineus” szóból származi melynek jelentése bérlő vagy vendég. Az inquilin életmódot általában a társbérlő javára egyoldalúan előnyös kapcsolatnak tekintik (Askew 1984). Ez a kleptoparazitizmus egyik formája, amelyet Ronquist (1994) 
javaslatára agasztoparazitizmusnak is neveznek. Ugyanakkor a cynipid darazsak esetében az igazi (obligát) inquilin kapcsolat sokkal több mint egy egyszerü egyoldalú kapcsolatnál (Askew 1984, Ronquist 1994, Csóka és mtsi 2005). Szigorú értelembe véve ez egy olyan kapcsolat két faj között amely csak egyikük számára előnyös viszont a partner számára nem jelent hátrányt. A hártyásszárnyúak körében sok példa van az inquilin kapcsolatra, különösen a szociális magatartású csoportok (méhek, darazsak és hangyák) körében (Askew 1984). A cynipid gubacsok esetében ezt a meghatározást egy rendszertanilag tág csoportra alkalmazzák amely tartalmazza az inquilin gubacsdarazsakat és közeli cynipoid rokonaikat, valamint molyokat, bogarakat és gubacsszúnyogokat. A cynipid gubacsok hártyásszárnyú (Hymenoptera) inquilinjei mind olyan cynipoid darazsak amelyek vagy a Synergini tribus (Cynipidae) vagy a Figitidae család Parnipinae, Thrasorinae, illetve Euceroptrinae alcsaládjába sorolhatóak (Ronquist és Nieves-Aldrey 2001, Ross-Farré és Pujade-Villar 2007, Buffington és Liljeblad 2008).

A cynipid inquilinek elvesztették azt a képességüket, hogy önmaguk gubacsképződést indítsanak el a gazdanövényen. Ennek ellenére fitofágok, valamint azon képességüket, hogy a gubacs öket közvetlenül körülvevő szöveteiben képesek a gubacsképző darazsak lárvakamrájában található jellegzetes táplálószövet kialakulását elöidézni. Egyes cynipid inquilinek képesek jelentősen megváltoztatni a gubacs szerkezetét aminek következtében a lárvák számától függően a gubacs nagyobb méretüvé válhat (Shorthouse 1973, 1980) vagy korcsosulhat (Washburn és Cornell 1981; Wiebes-Rijks 1982). Például ha a Diplolepis nodulosa (Beutenmüller) rózsa gubacsdarázs egykamrás gubacsait megtámadta az inquilin Periclistus pirata (Osten Sacken) akkor a 17 inquilin lárvakamrát tartalmazó gubacs mérete háromszorosára nőtt (Brooks és Shorthouse 1998). Tölgy gubacsok esetében a gazdagubacs szerkezetét legdrámaibb módon a Synophrus génusz tagjai képesek megváltoztatni. A génusz tagja az inquilin S. politus Hartig amely igen korai szakaszban megtámadja az „Andricus burgundus”komplexbe tartozó fajok szexuális generációjának apró gubacsait (Pujade-Villar és mtsi 2003). Úgy tünik, hogy a Synophrus lárva képes az egész gubacs differenciálódási folyamatot irányítani és csak a gubacs-indukció képességével nem rendelkezik (Pénzes és mtsi 2009). A S. politus gubacsa egykamrás amit az inquilin lárva teljesen kitölt. Azonban a Synophrus gubacsok strukturálatlannak tünnek a különböző, valódi gubacsképzők (Cynipini) gubacsaihoz képest. Még szembetűnőbb a nemrégiben Japánból leírt új inquilin faj, a Synergus itoensis Abe, Ide \& Wachi amelynek nevelési kísérletei bizonyították gubacs indukciós képességeit a Quercus glauca Thunb. makkján (Abe és msti 2011). Mindezen változások melyeket az inquilinek okoznak jelentősen megváltoztathatják a parazitoidok sikeres fertőzésének arányát és ezáltal befolyásolják az inquilinek és gubacs-képzők halálozási arányát. Az inquilineknek jelentősebb 
általános hatásuk lehet mint ahogyan azt sokáig gondolták (Sanver és Hawkins 2000).

Néhány cynipid inquilin a gubacs fejlődésének korai szakaszában megöli a gazda faj lárváját, feltételezhetően ebben az esetben trofikus kapcsolat is van köztük. Úgy tünik, hogy abban az esetben ha az inquilin tojások közel kerülnek a gazda lárvakamrájához akkor az inquilin lárvák és lárvakamrák gyorsabb fejlődésének következtében a gubacsképző összepréselődik és elpusztul (Weld 1952, Evans 1965, Shorthouse 1973, 1980, Wiebes-Rijks 1979). Ugyanazon inquilin faj egyik gubacs típusban letális hatással lehet a gazdára míg egy másik típusban melyben a perifériálisabb szövetekben fejlödik látszólag nincs semmiféle káros hatással a gubacsképző fejlődésére (Mayr 1872, Nieves-Aldrey 2001). A cynipid inquilinek egy részhalmaza a gubacsképzők jelentős mortalitását okozza (Duffet 1968). Egymással közel rokon inquilinek is teljesen eltérő hatással lehetnek a gubacsképző gazdájukra (Ács és mtsi 2010).

A legtöbb fajnak a gazdafajhoz szinkronizált, évente egy nemzedékből álló életciklusa van. A kifejlett egyedek általában a gubacsképzők után hagyják el a gubacsot és petéiket a friss, fiatal gubacsokba rakják le. A fajok egy része - különösen a Synergus génusz tagjai - évente két generációval is rendelkezhetnek melyek között néhány esetben generációs dimorfizmus is megfigyelhető (például a Synergus facialis esetében) (Wiebes-Rijks 1979, Melika 2006).

\subsection{Morfológia}

A dolgozatban szereplő morfológiai nevezéktan alapjául Ronquist és Nordlander (1989), Liljeblad és mtsi (2008) munkái, illetve a Hymenoptera Anatomy Ontology (HAO, Yoder és mtsi 2010) szolgált (http://glossary.hymao.org/projects/32/public/ontology/). A HAO nomenklatúra amelyet többnyire zárójelben tüntettem fel - szerepeltetése azért indokolt, mert így az itt használt morfológiai terminusok egyértelmüen összevethetőek a különböző taxonok között.

A Synergini tribusba tartozó cynipid inquilin fajok kifejlett egyedei 0,8-7 mm-es testhosszukkal kis és közepes méretü rovaroknak tekinthetőek és a következő általános szünapomorf morfológiai bélyegekkel jellemezhetőek:

- $\quad$ pofa (gena) nem vagy gyengén nyúlik be a szemek mögé (1/c ábra);

- a fej alsó részén (arc alsó része, lower face) a clypeus és a csápok töve (antennal rim) között általában sugárirányú striák (facial striae) láthatóak (1/a ábra);

- clypeus csak halványan látszik, ventrális szegélye (ventral clypeal margin) egyenes, nem szegélezett (1/a ábra);

- $\quad$ suboculáris barázda (subocular sulcus) hiányzik;

- a nyakszirti- (occipital foramen) és orális nyílás (oral foramen) között mért távolság 
(subforaminal bridge) nagyobb mint a nyakszirti nyílás magassága (1/b ábra);

- a hosszú posztgenális barázdák (postgenal sulcus) és posztgenális bordák (postgenal ridge) a hypostoma elérése előtt egyesülnek;

- a maxilla tapogatói (maxillary palp) 5 ízüek, a labium tapogatói (labial palp) 3 ízüek;

- a hímek csápja 14-15 ízböl áll, az első flagellomer (1st flagellomere) apikálisan rendszerint többé-kevésbé kiszélesedik. A nőstények csápja 12-14 ízü (1/d ábra);

- a középtest (mesosoma) egyenetlen felszínü (2/c ábra);

- a pronotum viszonylag hosszú, középen mért dorzális hosszúsága csak 1/5-1/3-a az oldalsó szegély mentén mért legkisebb távolsághoz képest (2/a ábra);
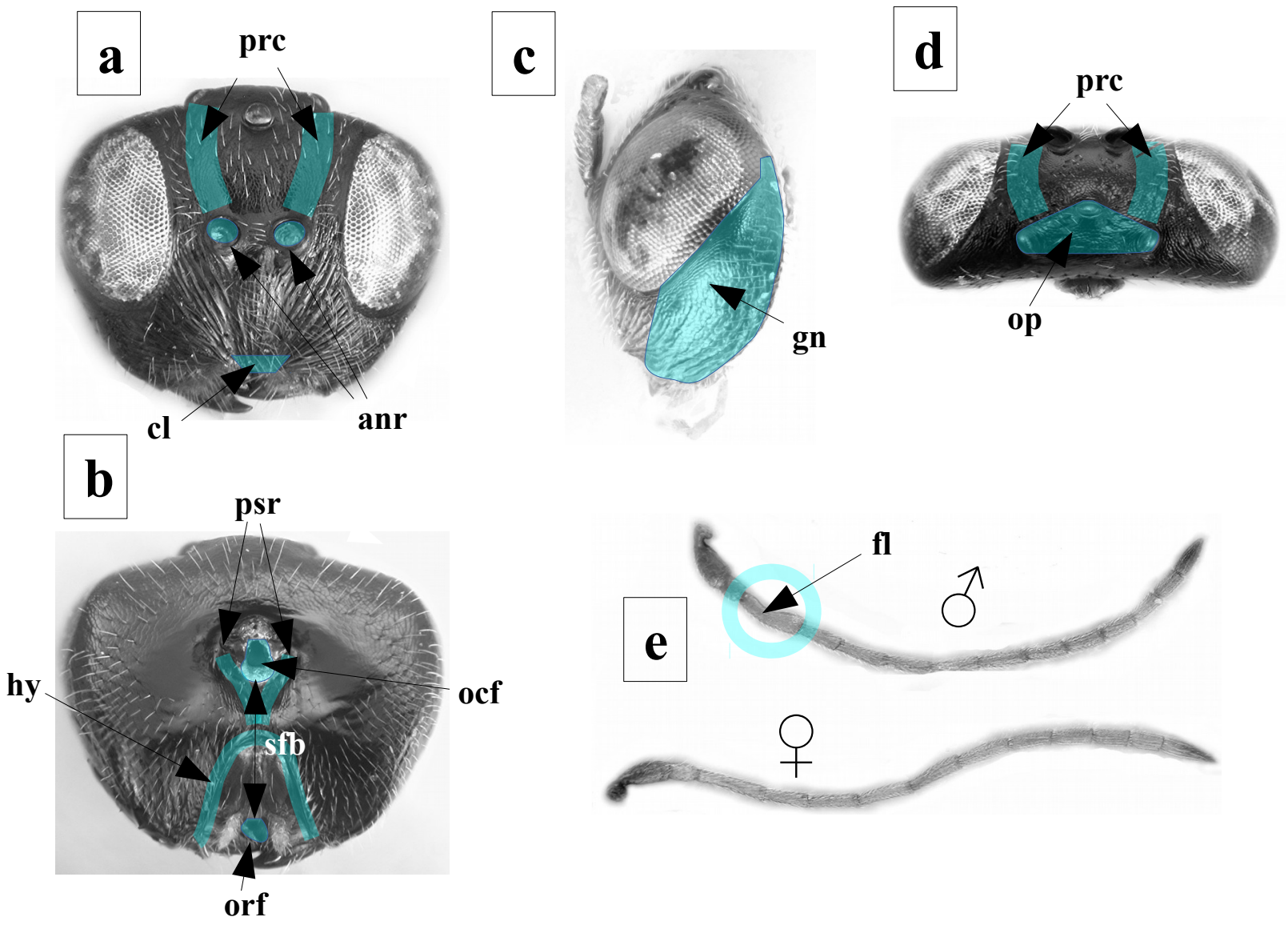

gn
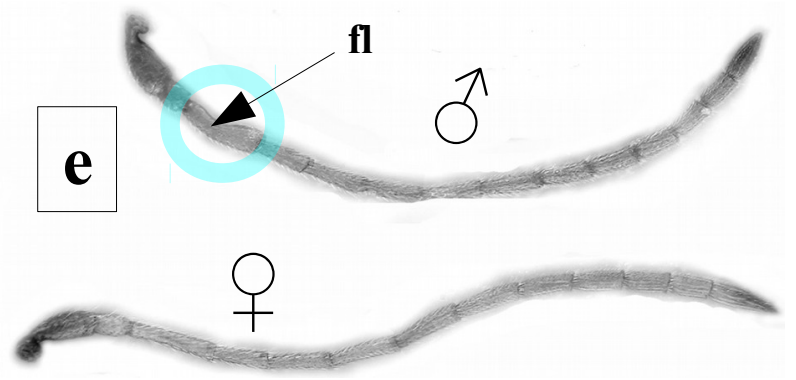

1. ábra Saphonecrus undulatus példány feje anterior (a),poszterior (b), laterális (c) és dorzális (d) irányból. A faj hím és nőstény egyedeire jellemző csápok (e). Rövidítések: gn = pofa (gena), $\mathrm{cl}=$ clypeus, anr $=$ a csápok ízesülési helye $($ antennal rim), $\mathrm{prc}=$ oldalsó frontális barázda (lateral frontal carina), $\mathrm{psr}=$ posztgenális barázdák és bordák (postgenal sulcus, postgenal ridge), ocf $=$ nyakszirti nyílás (occipital foramen), orf $=$ orális nyílás (oral foramen), $\mathrm{sfb}=$ subforaminal bridge, hy $=$ hypostoma, $\mathrm{fl}=1$. flagellomer, $\mathrm{op}=$ pontszemek által bezárt háromszög (ocellar plate)

- a pronotum mélyedései (pronotal pits, admedian depressions) általában feltünőek és 
középen egymással nem érintkeznek, néha egy gyenge pronotal plate-el összekapcsolódnak (2/a ábra);

- pronotum laterális barázdája (lateral pronotal carina) jelen van vagy hiányzik (2/c-d ábrák);

- az áltor (propodeum) laterális hosszanti barázdái (lateral longitudinal carina) többékevésbé párhuzamosak (2/b ábra);

- a Synergus thaumacerus hím egyedeinek kivételével teljesen kifejlett szárnyakkal rendelkeznek (a szárnyerek megnevezése Ronquist és Nordlander 1989 szerint van megadva);

- a lábtő karmok (tarsal claw) mellett bazális lebeny vagy fog található;

- az utótest (metasoma) 2. terguma (2nd metasomal tergum) redukálódott vagy gyürü alakú, dorzálisan hosszanti bordákkal (3. ábra);
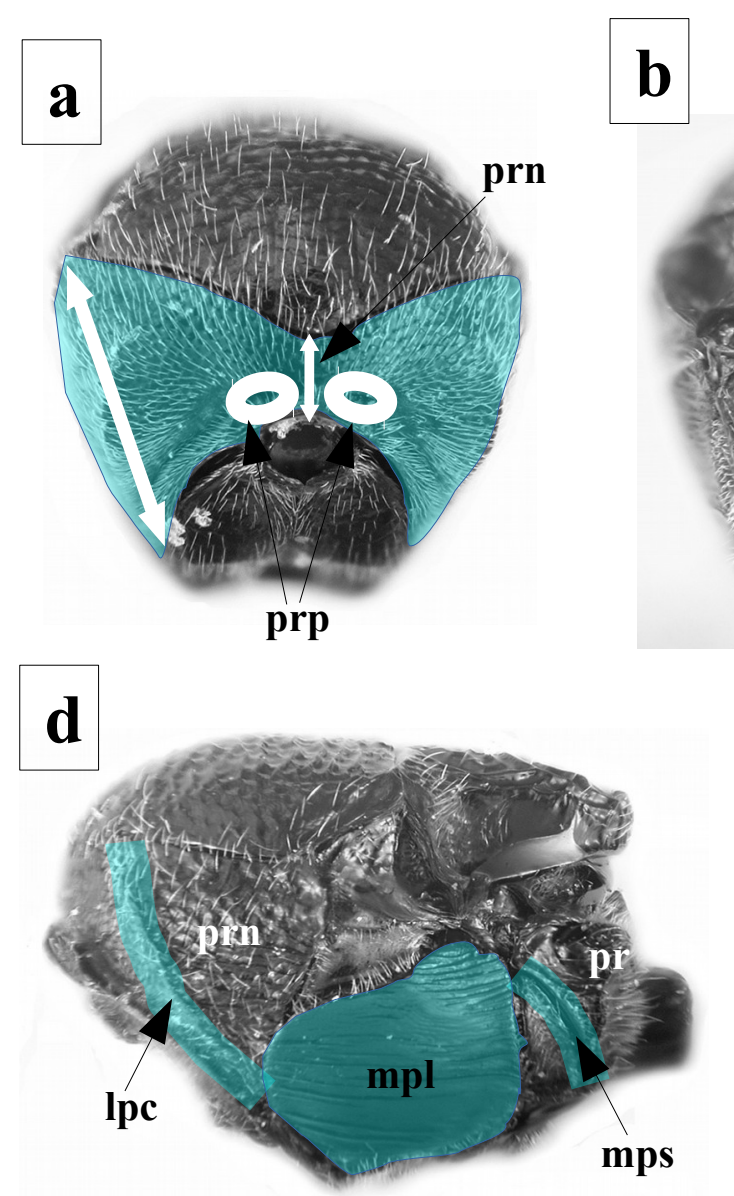

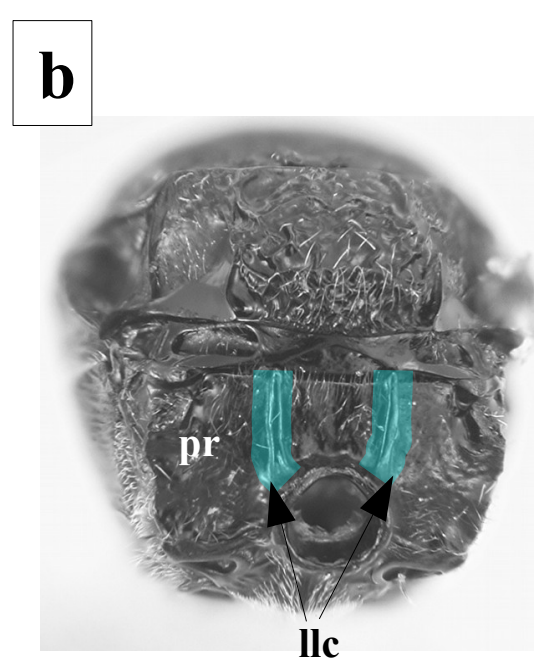

Ilc

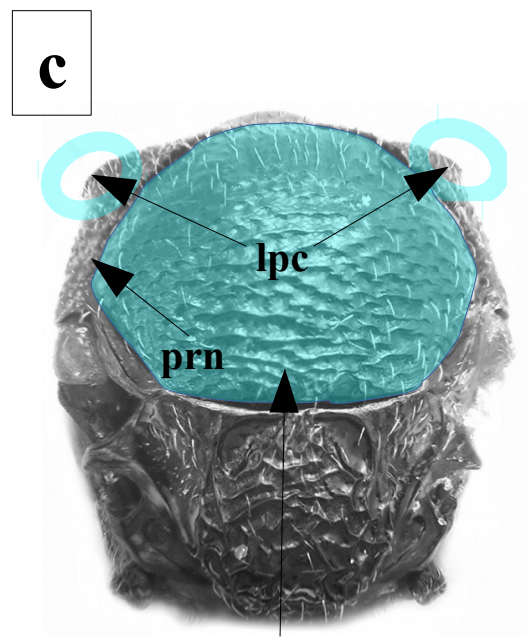

sc

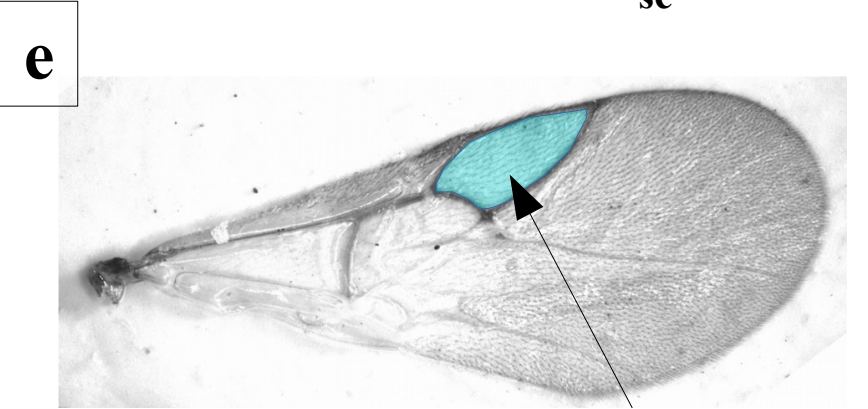

rac

2. ábra Saphonecrus undulatus példány középtest-ja anterior (a), posterior (b), dorzális (c) és laterális $(d)$ irányból.Synergus crassicornis 1 . pár szárnya (e). Rövidítések: prn = pronotum, prp = pronotal pits, $\mathrm{lpc}=$ pronotum oldalsó barázdája, $\mathrm{sc}=$ scutum, $\mathrm{pr}=$ propodeum, $1 \mathrm{lc}=$ lateral longitudinal carine, $\mathrm{mpl}=$ mesopleuron, $\mathrm{mps}=$ metapleural sulcus, $\mathrm{rac}=1$.pár szárny sugársejtje 

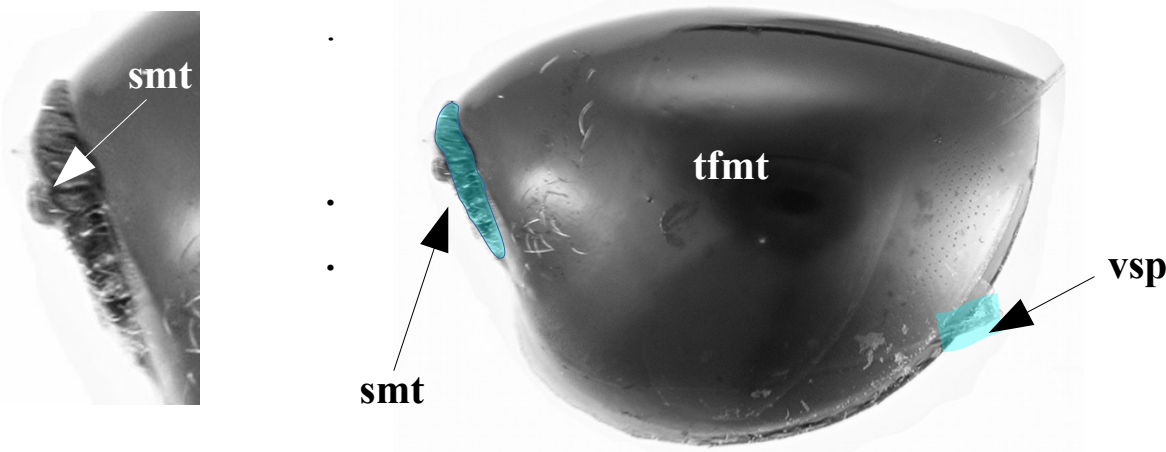

3.ábra Saphonecrus undulatus példány utótest-ja laterális irányból. Rövidítések: smt $=$ utótest 2. terguma, $\mathrm{tfmt}=$ utótest 3 . és 4 . terguma, $\mathrm{vsp}=$ a hypopygium ventrális barázdae.

- a utótest 3. (abdominal tergum 3) és 4. tergumai (abdominal tergum 4) ritkán különállóak, általában egymással egyesültek egy syntergum-ba amely szinte az egész utótestet elfedi (3. ábra);

- a hypopygium ventrális barázdaének (ventral spine of hypopygium) kiemelkedő része rövid (3. ábra)

A kutikuláris felszín terminológiája Harris (1979) munkáját követi (Melika és mtsi 2012, Bozsó és mtsi 2013). A génuszok elkülönítése Melika és mtsi (2005) és Bozsó és mtsi (2013) cikkeiben közölt morfológiai kulcsok alapján történik.

\subsection{A Synergini tribus fajainak földrajzi elterjedése}

Az eddig említett 9 génusz föleg az északi félteke mérsékelt égövében, a Holarktikus régióban elterjedt, ezzel szemben az Agastroxenia génusz csak a Neotropikus régióból ismert, valamint 14 Synergus fajról számoltak be Panamából és Guatemalából (Nieves-Aldrey és Medianero 2011) (2. táblázat). A Synegrus-komplexbe sorolt hat génusz fajai a bükkfafélék (Fagaceae) családjába tartozó tölgy és tölgy-rokon nemzetségek fajain található cynipid gubacsokban fejlődő inquilinek (Csóka és mtsi 2005, Melika és mtsi 2005, van Noort és mtsi 2007, Ács és mtsi 2010, Nieves-Aldrey és Medianero 2010). A Periclistus Föster 1869 az egyetlen génusz melynek inquilin cynipid fajai a rózsaféléken található Diplolepidini (Cynipidae) tribus gubacsaihoz társíthatóak.

Néhány, tölgyfélék gubacsaihoz kapcsolható inquilin faj szintén ismert az Orientális régióból: a Fülöp-szigetekről 2 Saphonecrus faj (Weld 1926), Kína Orientális régiójából néhány napjainkban leírt Saphonecrus faj (Wang és mtsi 2010, Liu és mtsi 2012) valamint Tajvanról az Ufo génusz négy faja (Melika és msti 2012).

A Rhoophilus Mayr, 1881 érdekes biogeográfiai problémát vet fel. Egyetlen ismert faja a 
R. loewi Mayr, 1881 és ez az egyetlen cynipid génusz amelynek elterjedési területe Dél-Afrika etiópiai régiójára korlátozódik (Mayr 1881, van Noort és mtsi 2007). Az Eschatocerini cynipid gubacsaiból jelenleg nem ismerünk cynipid inquilin fajokat, valamint nagyon kevés faj ismert az Aylacini cynipid gubacsaiban is. Ezen kivételes fajok a Synophromorpha Ashmead, 1903 génusz fajai (melyek a szederfélék (Rubus spp., Rosaceae) hajtásain található Diastrophus Hartig, 1840 cynipid gubacsokban fejlődnek (Ritchie 1984, Ritchie és Shorthouse 1987). A cynipid inquilinek fitofágok így erösebb kényszert jelenthet, hogy jobban kötődnek az egyes gazdanövény taxonokhoz mint az adott gubacsindukáló gazdafajukhoz (Pénzes és mtsi 2012).

$\mathrm{Az}$ ismert Synergini fajok egyenlőtlenül oszlanak el az biogeogáfiai régiók között (2. táblázat). Jelenleg 48 fajt tartunk számon a Nyugat-Palearktikumból. Nem kétséges, hogy ez a legalaposabban vizsgált régió ezért nem várható, hogy a további kutatások eredményeként itt jelentősen változni fog a leírt fajok száma. Az ismert Kelet-Palearktikus fajok száma az utóbbi

\begin{tabular}{|c|c|c|c|c|c|c|c|c|}
\hline \multirow{2}{*}{ Génusz } & \multirow{2}{*}{$\begin{array}{l}\text { Növé ny- és } \\
\text { gubacs gazda }\end{array}$} & \multicolumn{6}{|c|}{ Elte rje dés s te rület } & \multirow{2}{*}{ Fajszám } \\
\hline & & WP & EP & OR & NA & NT & ET & \\
\hline $\begin{array}{c}\text { Agastoroxenia } \\
\text { Nieves-Aldrey et } \\
\text { Medianero, 2010 }\end{array}$ & $\begin{array}{c}\text { Tölgyfélék (Quercus, } \\
\text { Fagaceae), cynipid faj } \\
\text { gubacsa }\end{array}$ & - & - & - & - & 1 & - & 1 \\
\hline $\begin{array}{c}\text { Ceroptres } \\
\text { Hartig, } 1840\end{array}$ & $\begin{array}{c}\text { Tölgyfélék (Quercus, } \\
\text { Fagaceae), cynipid faj } \\
\text { gubacsa }\end{array}$ & 2 & 4 & - & 17 & - & - & 23 \\
\hline $\begin{array}{c}\text { Synergus } \\
\text { Hartig, } 1840\end{array}$ & $\begin{array}{c}\text { Tölgyfélék (Quercus, } \\
\text { Fagaceae), cynipid faj } \\
\text { gubacsa }\end{array}$ & 30 & 10 & - & 55 & 14 & - & 109 \\
\hline $\begin{array}{c}\text { Saphonecrus Dalla } \\
\text { Torre \& Kieffer, } \\
1910\end{array}$ & $\begin{array}{c}\text { Tölgyfélék (Quercus, } \\
\text { Fagaceae), cynipid faj } \\
\text { gubacsa }\end{array}$ & 6 & 9 & 2 & 4 & - & - & 21 \\
\hline $\begin{array}{l}\text { Synophrus } \\
\text { Hartig, } 1843\end{array}$ & $\begin{array}{c}\text { Tölgyfélék (Quercus, } \\
\text { Fagaceae), cynipid } \\
\text { fajok }\end{array}$ & 7 & - & - & - & - & - & 7 \\
\hline $\begin{array}{c}\text { Ufo } \\
\text { Melika \& Pujade, } \\
2005\end{array}$ & $\begin{array}{c}\text { Tölgyfélék (Quercus, } \\
\text { Fagaceae), cynipid faj } \\
\text { gubacs a }\end{array}$ & - & 3 & 1 & - & - & - & 4 \\
\hline \begin{tabular}{|c|} 
Periclistus \\
Förster, 1869
\end{tabular} & $\begin{array}{c}\text { Rózs afélék } \\
\text { (Rosaceae), cynipid faj } \\
\text { gubacsa }\end{array}$ & 3 & 4 & - & 7 & - & - & 14 \\
\hline $\begin{array}{c}\text { Synophromorpha } \\
\text { Ashmead, } 1903\end{array}$ & $\begin{array}{c}\text { Szederfélék (Rubus, } \\
\text { Rosaceae) gubacsai }\end{array}$ & - & 2 & - & 4 & - & - & 6 \\
\hline $\begin{array}{l}\text { Rhoophilus } \\
\text { Mayr, } 1881\end{array}$ & $\begin{array}{c}\text { Rhus nemzetség } \\
\text { (Anacardiaceae) } \\
\text { gubacsai }\end{array}$ & - & - & - & - & - & 1 & 1 \\
\hline \multicolumn{2}{|c|}{ Összesen: } & 48 & 32 & 3 & 87 & 15 & 1 & 186 \\
\hline
\end{tabular}

2. táblázat: A Synergini törzs génuszainak elterjedése és fajszáma állatföldrajzi régik szerint Rövidítések: $\mathrm{WP}=$ Nyugat-Palearktikum, $\mathrm{EP}=$ Kelet-Palearktikum, $\mathrm{OR}=$ Orientális régió, $\mathrm{NA}=$ Nearktikum, NT $=$ Neotropikus régió, ET = Etióp régió (Melika és mtsi (2012) alapján) 
évtizedben jelentősen növekedett és valószínü, hogy néhány kínai és tajvani, cynipid fajokkal foglalkozó kutatócsoport tevékenységének köszönhetően ez a tendencia továbbra is fennmarad. Hasonlóan növekvő fajszámok jellemzik a neotrópusi régiót is ahonnan jelentős számú új fajt írtak le az utóbbi időben (Nieves-Aldrey és Medianero 2010, 2011). Az USA-ból és Kanadából leírt nagyszámú inquilin faj alapján várhatóan Mexikó nagy kiterjedésű, florisztikailag és faunisztikailag értékes régióiban folytatott kutatások a jövőben feltárják a Synergini tribus eddig még rejtett sokszínü diverzitását.

Az alábbiakban Melika és mtsi (2012) alapján összefoglalom a Synergus-komplexbe sorolt, vizsgálatunkban szereplö génuszok életmódját és diverzitását.

\section{Synergus Hartig, 1840}

Típus faj: Synergus vulgaris Hartig, 1840.

Mayr (1872) a tölgyfákon élő inquilinek legfajgazdagabb génuszát két részre osztotta: Az I. szekció fajainak túlnyomó része évente csak egy nemzedékkel rendelkezik (univoltin) és a gazda gubacson belüli fejlődésük ritkán okozza a gubacs indukáló gazda halálát. Ezzel szemben II. szekció fajainak jellemzően évente két generációjuk van (bivoltin) és fejlődésük gyakran a gubacsképző faj pusztulását eredményezi (Csóka és mtsi 2005). Kifejlett egyedek egyes morfológiai tulajdonságait (pl. testnagyság és színezet) figyelembe véve a II. szekció fajait a generációk közti morfológiai eltérés olyan magas foka is jellemzi (Nieves-Aldrey és PujadeVillar 1986, Pujade-Villar 1992, Wiebes-Rijks 1979) ami megnehezíti a fajok morfológiai alapú azonosítását. Ennek eredményeként morfológiai alapon sok esetben csak a morfológiailag hasonló fajok komplexumainak azonosítása lehetséges (Ács és mtsi 2010).

A fajok főként Holarktikus elterjedésüek azonban néhány faj az Orientális Kínából és a Neotropikus régióból is ismert. Jelenleg a Palearktikumban 40 fajt tartanak számon: 30-at a Nyugat-Palearktikumból (Pujade-Villar és mtsi. 2003, Sadeghi és mtsi. 2006) és 10-et a KeletPalearktikumból. 55 faj ismert a Nearktikumból, ezek közül 44 Mexikótól északra él. Jelenleg a Neotropikus régióból 14 fajt ismerünk (2. táblázat), gazdanövényeik főként a Quercus génusz Lobatae szekciójába tartoznak (Pénzes és mtsi 2012).

\section{Synophrus Hartig, 1843}

Típus faj: Synophrus politus Hartig, 1843.

A Nyugat-Palearktikumból jelenleg 7 Synophrus faj ismert (2. táblázat), ezek mindegyike képes arra, hogy a gazdagubacs fenotípusát a saját fajára jellemző módon átalakítsa (Pénzes és mtsi 2009). Busks (1979) a Synophrus mexicanus (Gillette, 1896) fajt listázta a Nearktikumra, 
amelyet Pujade-Villar és Melika (2005) áthelyezett a Synergus génuszba.

A Synophrus génuszt eredetileg gubacsképző fajok csoportjának tartották (Hartig 1843) majd később a kifejlett egyedek morfológiája alapján áthelyezték a Synergigi tribusba (Ronquist 1994). Az inquilin életmenetet közvetett bizonyítékok alátámasztották. A génusz fajai fejlődésük során minden esetben letális hatásúak a gubacsgazdára, mindazonáltal a gazdagubacsnak ilyen mértékủ módosítása extrémnek számít a cynipid inquilinek között.

\section{Ufo Melika \& Pujade-Villar, 2005}

Típus faj: Ufo abei Melika et Pujade-Villar, 2005.

A génusznak összesen négy faja ismert (2. táblázat): három a Kelet-Palaearktikumból, egy pedig az Orientális régióból. Tipikus a fajok gazdanövény asszociációja, minden esetben a Quercus génusz Cerris szekciójának fajain fejlődő gubacsokat támadják meg (Melika és mtsi 2012). A génusz revízióját, fajkulcsát és két új faj leírását Melika és mtsi (2012) cikkben jelentettük meg.

\section{Saphonecrus Dalla Torre et Kieffer, 1910}

Típus faj: Synergus connatus Hartig, 1840.

A Saphonecrus génuszt Dalla Torre és Kieffer 1910-ben azért hozta létre, hogy ebbe sorolja be a nyitott radiális sejttel rendelkező, tölgyeken élö inquilin fajokat. A NyugatPalearktikus fajok többsége - a mediterrán örökzöld fajokat (Q. ilex, $Q$. suber, $Q$. coccifera) valamint a közép-európai $Q$. cerris-t is magában foglaló - a Quercus génusz Cerris szekciójának gubacsaihoz kapcsolódik míg néhány faj a génusz Quercus szekciójának fajain (pl. Q. petraea, Q. robur) fejlödött gubacsokhoz társult. A fenti két tölgyszekció lombhullató fajain fejlödő inquilin fajoknak évente egyetlen generációjuk van és áttelelésük után rajzanak ki kifejlett egyedeik a gazdagubacsokból. Ezzel szemben az örökzöld fajokon fejlődő inquilineknek legalábbis potenciálisan évente két generációjuk fejlődhet ki (Pujade-Villar és Nieves-Aldrey 1990). Ezek ismeretében életmódjuk alapján az európai Saphonecrus fajokat három csoportra osztották: az első csoportba tartozó fajoknak évente egyetlen generációjuk van és a Quercus tölgyszekcióhoz kötődnek (pl. S. connatus); a második csoportba szintén monovoltin fajok tartoznak amelyek a Cerris tölgyszekcióhoz társíthatóak (ide sorolják többek között a $S$. undulatus, $S$. haimi és $S$. irani fajokat); a harmadik csoport tagjai olyan kétnemzedékes mediterrán fajok amelyek az örökzöld tölgyek gubacsaiban fejlödnek ( $S$. barbotini és $S$. gallaepomiformis) (Pujade-Villar és Nieves-Aldrey 1990).

Napjainkig a Saphonecrus génusznak 23 faját írták le (függelék: I. táblázat). A génusz 
főként Holarktikus elterjedésü: a Nyugat-Palearktikumból 6 faj ismert melyek közül egyesek taxonómiai helyzete bizonytalan (Pujade-Villar és mtsi 2003); 7 fajt a Kelet-Palearktikumból jegyeztek fel (Abe és mtsi 2007); 4 faj a Nearktikumból (Burks 1979) valamint az Orientális régióból csak 2 faj ismert (Weld 1926).

A kutatásaink alapján egy, a Saphonecrus génuszhoz közelálló új génusz Lithosaphonecrus Tang, Melika\&Bozsó, 2013 - került leírásra (Bozsó és mtsi 2013).

\subsection{A tölgyféléken élő cynipid inquilinek gazdanövény kapcsolatai}

A cynipid inquilinek elsősorban gubacsdarazsakhoz asszociálódnak. Annak érdekében, hogy megértsük a gubacsdarazsak evolúcióját ismernünk kell gazdanövény kapcsolataikat is. A fejezetben röviden áttekintem a tölgyek és tölgyekhez kapcsolódó nemzetségek taxonómiáját, diverzitását, elterjedését, filogenetikai és filogeográfiai jellemzőit és kitérek rá, hogy mindezek hogyan befolyásolhatták a cynipid inquilinek filogenetikáját.

A Nyugat-Palearktikus tölgy gubacsdarazsak legújabb filogenetikai elemzései az eltérő tölgyszekciókhoz kapcsolódó gubacsdarázs génuszok között korai ekülönülést tártak fel (Cook és mtsi 2002, Ács és mtsi 2007, Liljeblad és mtsi 2008, Stone és mtsi 2009). Ugyanez érvényes a Kelet-Palearktikumból a Quercus nemzetség Cyclobalanopsis szubgénuszáról nemrégiben leírt Cycloneuroterus Melika \& Tang, 2011 és Cyclocynips Melika, Tang \& Sinclair, 2013 génuszokra is (Tang és mtsi 2011b, Melika és mtsi 2013). Az inquilinek - különösen a Synergus-komplex esetében gazdanövények szerint szintén korán szétváltak a leszármazási sorok (Ács és mtsi 2010).

A tíz élő nemzetséget és a csak maradványokból ismert Fagopsis génuszt magában foglaló bükkfafélék (Fagaceae Dumort) családja az egész északi féltekén elterjedt, változatos élőhelyek uralkodó fafajait tartalmazza. Két nagyon változatos morfológiai tulajdonságokkal jellemezhető alcsaládra bontható: a) Fagoidea alcsaládba tartozik többek között a bükkök (Fagus) és tölgyek (Quercus) nemzetsége, szinte az összes ismert Cynipini faj gazdanövénye az utóbbi nemzetség tagja; b) Castaneoidea alcsalád azzal az öt rovar beporzású nemzetséggel (Castanea, Castanopsis, Chrysolepis, Lithocarpus és Notholithocarpus) melyek mindegyike tartalmaz olyan fajokat amelyek szintén gazdanövényei lehetnek a Cynipini fajoknak (Govaerts és Frodin 1998, Manos és mtsi 2008, Bozsó és mtsi 2013) (4. ábra)

Manos és mtsi (2001) a Lithocarpus nemzetségnek világszerte 334 faját említik míg mások csak maximum 100 fajt sorolnak ide (Flora of Taiwan 1996). A korábban mintegy 100 fajt tartalmazó Pasania génuszt a Lithocarpus-ba szinonimizálták (Govaerts és Frodin 1998). Az ide sorolt összes faj Kelet- és Délkelet-Ázsiában őshonos. Egyes Saphonecrus inquilinek a 


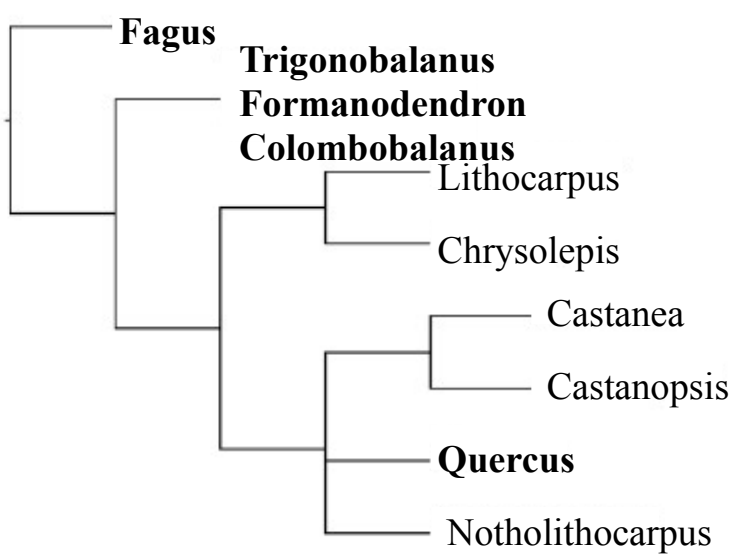

4. ábra: A Fagaceae család feltételezett filogenetikája (Oh és Manos (2008) alapján) A Fagoidea alcsalád tagjait vastag betüvel kiemeltem.

Lithocarpus fajokon fejlődő cynipid gubacsdarazsakhoz társulnak.

Az arany babérgesztenyék (Chrysolepis) nemzetsége az Egyesült Államok nyugati területein őshonos (Washington Állam nyugati régióitól déli irányban Dél-Kaliforniáig és keleti irányban Nevadáig). A nemzetség képviselőin fejlődő néhány cynipid gubacsdarázs fajhoz inquilin fajok is társíthatóak.

A gesztenyék (Castanea) nemzetségébe 8-10 faj tartozik amelyek az északi félteke mérsékelt égövében őshonosak. A génusz képviselőin fejlődő egyetlen gubacsdarázs faj (Dryocosmus kuriphilus Yasumatsu) gubacsaiból eddig még csak egyetlen esetben neveltek ki inquilin fajt - Japánból gyüjtött gubacsból egy Synergus faj nőstény példányát (Ôtake és mtsi 1982) - ami vagy azt bizonyítja, hogy ebben az esetben extrém ritkán társulnak társbérlő fajok a D. kuriphilus-hoz vagy az is előfordulhat, hogy a nem elég körültekintően végzett nevelés miatt ez csupán egy hamis adat.

A babérgesztenyék (Castanopsis) nemzetségébe mintegy 120 örökzöld faj tartozik melyek elterjedése jelenleg a trópusi és szubtrópusi Kelet-Ázsiára korlátozódik (Manos és Stanford 2001, Oh és Manos 2008). 58 őshonos, 30 endemikus faj él Kínában. A többi faj ettől délebbre, Indokínától Indonéziáig elterjedt és kevés fajuk Japánból is ismert. A nemzetség képviselőin fejlődő néhány cynipid gubacsdarázs fajhoz inquilin fajok is társíthatóak.

A nemrégiben létrehozott Notholithocarpus nemzetség csak egyetlen, az Egyesült Államok nyugati felében, Kaliforniában élő őshonos örökzöld fajt, a N. densiflorus-t tartalmazza 
(Manos és mtsi 2008, Oh és Manos 2008).

A Cynipini tribus fajainak többsége a nagy, rendszertanilag problémás, szélbeporzású Quercus génusz tagjain indukál gubacsokat melyet két szubgénuszra bontanak szét: a kizárólag csak ázsiai fajokat tartalmazó Cyclobalanopsis- és a sokkal szélesebb körben elterjedt Quercus szubgénuszra (Camus 1936-54, Nixon 1985, 1993, Govaerts és Frodin 1998, Manos és mtsi 1999).

A Quercus alnemzetséget molekuláris filogenetikai vizsgálatok alapján a számos különálló szekciókra bontják fel (Govaerts és Frodin 1998, Manos és mtsi 1999, Manos és Stanford 2001) (5. ábra): Lobatae (vörös tölgyek), Protobalanus (átmeneti tölgyek), Quercus sensu stricto (fehér tölgyek) és Cerris (csertölgyek). A fenti csoportosítás kissé eltér a morfológián vagy biokémiai jellemzőkön alapuló felosztástól (pl. Nixon 1993, Zhou és mtsi 1995).

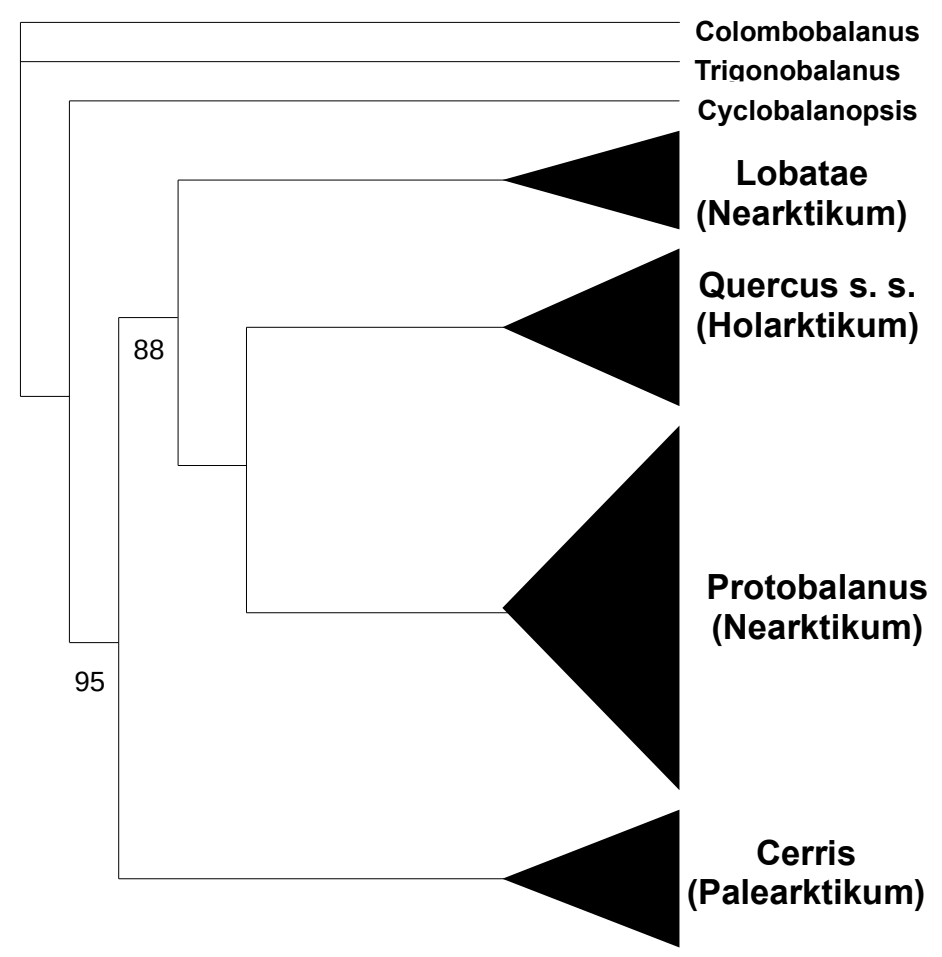

5. ábra: A Quercus szubgénusz kloroplaszt DNS restrikciós helyeinek és nukleáris ITS DNS szekvenciáinak párhuzamos elemzése alapján készített strict konszenzus fája. A tengelyek mellett a százalékos bootstrap értékeket tüntettem fel. (Manos és mtsi (1999) alapján, módosítva)

A Cerris szekciót két alszekcióra osztották fel: az örökzöld fajokat tartalmazó Ilex fajcsoportra és a félig lombhullató fajok Cerris fajcsoportjára (Nixon 1993). A Quercus szekció Holarktikus, a Lobatae és Protobalanus szekciók kizárólag Nearktikus, a Cerris szekció pedig kizárólag Palearktikus elterjedésü.

Világszerte 531 tölgyfajt ismernek el (Govaerts és Frodin 1998) melyek közül 76 faj a Délkelet-ázsiai Cyclobalanopsis szubgénusz, 455 faj pedig a sokkal elterjedtebb Quercus 
szubgénusz tagja. A Quercus alnemzetség fajai legnagyobb arányban az északi félteke mérsékelt égövében fordulnak elö. A Neotropikus régióban a tölgyek déli irányban egészen a Kolumbiai Andokig megtalálhatóak (Nieves-Aldrey 2005). A Kelet-Palearktikumban a Keleti-Himalájától déli irányban a Fülöp-szigeteken és Malajzián keresztül egészen Jáváig a tölgyek és különösen a Cyclobalanopsis fajok hegyvidéki területek klimax erdeinek fö összetevői (Docters van LeuwenReijnvaan és Docters van Leuwen 1926).

A tölgyek fajgazdagsága jelenlegi ismereteink szerint a Nearktikumban a legmagasabb (mintegy 300 faj) melynek epicentruma a mexikói Sierra Madre Occidental a maga 135-200 fajával (Nixon 1993, Manos és mtsi 1999). A Palearktikus régió mintegy 170 fajából 130 a Kelet-Palearktikumban él és csak 29 fajt ismernek a Nyugat-Palearktikumból (Govaerts és Frodin 1998). Utóbbiak közül 13 a Cerris, 16 a Quercus szekció tagja. A Nyugat-Palearktikum alaposan tanulmányozott tölgy flórájának kizárólag egyetlen faja, a Q. cerris ismert a NyugatPalearktikumon kívül más régióból (ebben az esetben Nyugat-Afganisztánból) is (Govaerts és Frodin 1998). A Cerris és Quercus szekciók fajai a Kelet-Palearktikumban széles körben elterjedtek és ismert regionális fajgazdagságuk - a Kínában élő 32 fajnak (Linkuo és Tao 1998), a Himalája indiai oldalán, Nepálban és Bhutánban élö legalább 17 fajnak (Negi és Naithani 1995) és a Japánból ismert 6 fajnak (Ohwi 1961) köszönhetően - meghaladja a NyugatPalearktikum 29 faját. Azonban a tényleges fajszám még ennél lényegesen nagyobb lehet.

\subsection{A Synergini tribus rendszerezése}

A Cynipoid darazsak (Cynipoidea) két csoportra oszthatóak: macrocynipoidákra és microcynipoidákra (Ronquist 1995, 1999). A fitofág gubacsdarazsak (gubacsképzők és inquilinek, Cynipidae) a microcynipoidák csoportjába tartoznak. Az utóbbi évtizedben a Cynipoidea és különösképpen a Cynipidae a kifejlett példányok morfológiai karakterein, a génszekvenciákon és a gubacsok szerkezetén alapuló intenzív filogenetikai kutatások tárgyát képezte (Ács és mtsi 2007, Ács és mtsi 2010, Cook és mtsi 2002, Liljeblad 2002, Liljeblad és Ronquist 1998, Liljeblad és mtsi 2008; Melika és mtsi 2010, Nieves-Aldrey és mtsi 2005, Nylander 2004a, Pénzes és mtsi 2009, Rokas és mtsi 2003, Ronquist és Liljeblad 2001, Ronquist és NievesAldrey 2001, Stone és Cook 1998). A macrocynipoidák bazális helyzetü, parafiletikus csoportja az Austrocynipidae, Ibaliidae, és Liopteridae családokra bontható szét. A microcynipoidák monofiletikus eredetủek és két testvér leszármazási vonaluk, a fitofág Cynipidae és a parazita Figitidae (s. lato) családok egyaránt monofiletikusak (7. ábra).

A Cynipidae magasabb filogenetikai kapcsolataival az utóbbi időben számos szerző foglalkozott (Ronquist 1994, 1999, Liljeblad és Ronquist 1998, Liljeblad és mtsi 2008, Ronquist 
és Liljeblad 2001, Nylander 2004a). A fitofág cynipid gubacsdarazsak és inquilinek egy természetes csoportot alkotnak. Egyedülálló fitofág életmódjuk mellett számos szünapomorf morfológiai tulajdonságuk ismert (Liljeblad és Ronquist 1998). Azonban egy nemrégiben készült molekuláris filogenetikai analízis eredménye megkérdőjelezi a családon belül felállíott csoportok (Liljeblad és Ronquist 1998, Ronquist 1994, 1999, Ronquist és Liljeblad 2001) monofiletikus eredetét (Nylander 2004a). A vizsgált DNS szekvenciák alapján a tölgyekhez nem kapcsolódó, fásszárú rózsaféléken gubacsot indukáló tribus-ok (Diplolepidini, Eschatocerini és Pediaspidini) nem alkotnak monofiletikus csoportot és csak távoli rokonságba állnak a Cynipini tribus-al.

A korai taxonómusok (Hartig 1840, Ashmead 1903) morfológiai hasonlóságaik alapján az összes társbérlő fajt egyetlen csoportba vonták össze. Azonban mások úgy vélték, hogy a társbérlők polifiletikus eredetüek és minden inquilin faj szorosabb kapcsolatban van a saját gubacsképző gazdafajával (Askew 1984). Shorthouse (1980) úgy vélte, hogy az inquilinek olyan típus képviselői melyek sohasem voltak képesek a fejlődésükhöz szükséges gubacs indukcióra. A morfológiai bizonyítékok már régóta támogatták azt az elméletet, hogy a Synergini tribus egy olyan monofiletikus csoportnak tekinthető ami a lágyszárú növények gubacsdarazsainak parafiletikus Aylacini tribus-án belül alakult ki és legközelebbi őseik a Diastrophus és Xestophanes génuszok (Ronquist 1994, Ronquist és Liljeblad 2001, Liljeblad 2002, Liljeblad és mtsi 2008) (6. ábra).

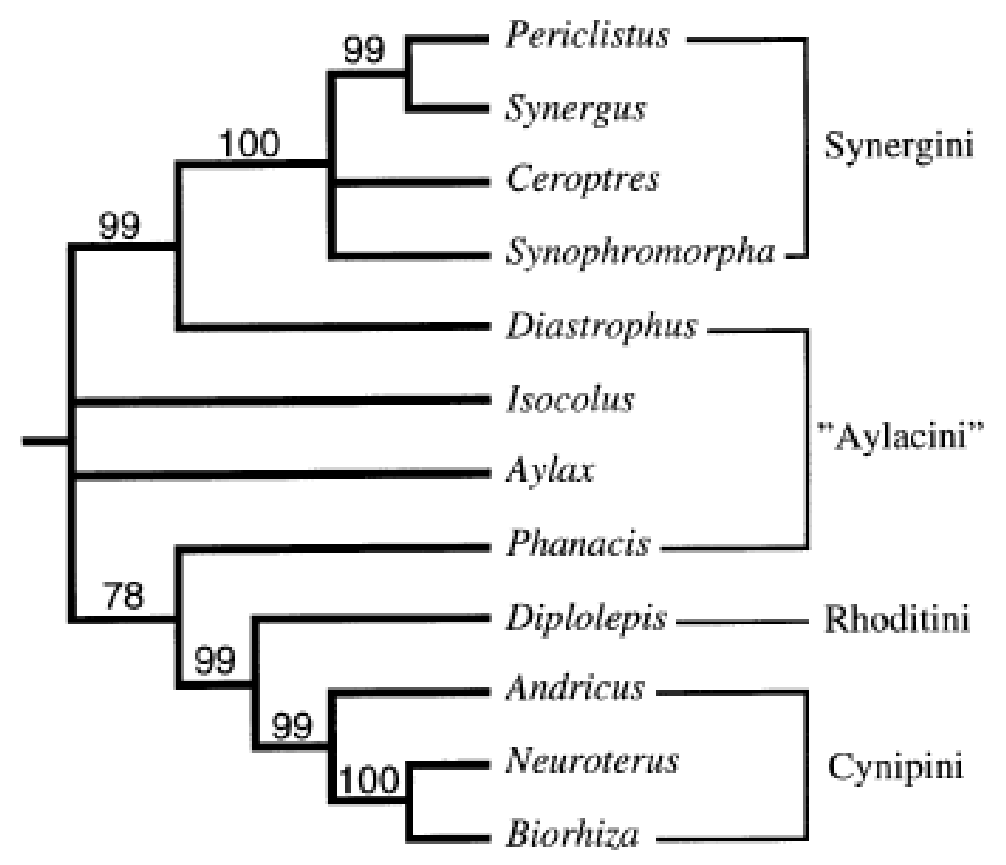

6. ábra: A Cynipidae magasabb szintü kapcsolatainak hipotézise a kifejlett egyedek 108 morfológiai karakterének parszinónia elemzése alapján. Az ágakon a százalékosbootstrap értékek láthatóak.(Ronquist 1994 alapján) 
Liljeblad (2002) feltételezése szerint a tölgy gubacsok cynipid társbérlöi a Diastrophus génusszal közel rokon gubacsképző cynipidákból - a rózsaféléken cynipid gubacsdarazsak által képzett gubacsok átmeneti inquilinizmusán keresztül - alakulhattak ki. Ezért ez az elmélet a tölgyek cynipid inquilinjeit és a rózsafélék - Periclistus és Synophromorpha nemek fajai által képviselt - inquilinjeit közeli rokonoknak tartotta.

Az inquilineket jelenleg a fajok olyan polifiletikus - vagy parafiletikus - együttesének tartják amelyben egymástól elkülönülnek a tölgyek és a rózsafélék cynipid fajaihoz asszociálódott társbérlő fajok. Ugyanakkor a molekuláris filogenetikai bizonyítékok is arra utalnak, hogy a Synergini tribus nem monofiletikus, hanem az Aylacinin belül egymástól függetlenül kialakult 3 leszármazási vonalra osztható (Nylander 2004a, Melika 2006, van Noort és msti 2007) (7. ábra): (1.) a rózsafélékhez kötődő Synophromorpha-Periclistus csoport, (2.) a tölgyhöz kötődő Ceroptres génusz és (3.) a Synergus-komplex, amely a szintén tölgyhöz kötődő génuszokból, valamint a Rhoophilus génuszból áll. Ugyanakkor az inquilinek eredetével kapcsolatos ellentmondások nem tekinthetőek teljesen megoldottnak. Megbízható filogenetikai elemzéshez a taxonok részletesebb mintavétele szükséges, azonban az elemzés még így is problémákba ütközhet.

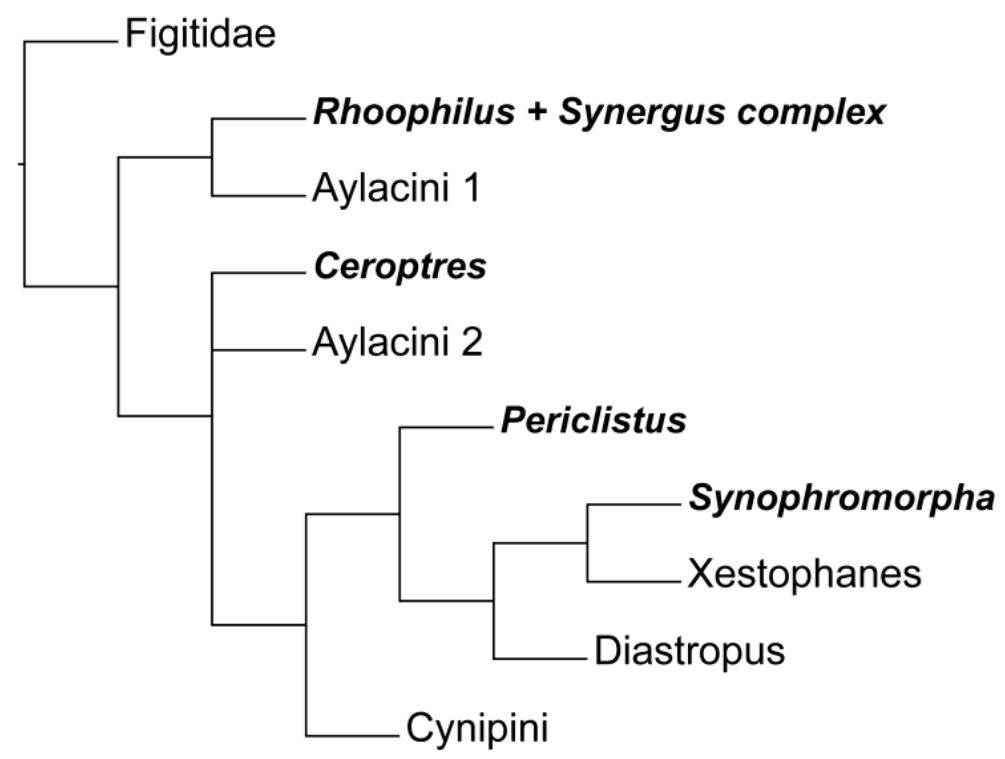

7. ábra: A Synergini törzs és egyéb gubacsképző Cynipidae taxonok filognetikai kapcsoltai. A Synergini tribus tagjait vastag betüvel kiemeltem. (Nylander 2004 alapján)

A Ceroptres génusz tölgyekhez kapcsolódó inquilin fajai független eredetü külön törzsfejlődési vonalat alkotnak azonban az összes molekuláris és morfológiai elemzésbe csak a génusz Nyugat-Palearktikus fajait vonták be. Morfológiailag a Ceroptres génusz fajai meglehetősen különböznek a Synergus-komplex összes többi fajától. Azonban a génusz észak- 
amerikai fajai néhány sajátosságukban jobban hasonlítanak a Synergus-komplex többi fajára és közülük néhány fajnak a petioláris gyürüjének (petiolar annulus) szerkezete apomorf jellegeket mutat a Synergus génusszal (Ritchie 1984, Liljeblad és Ronquist 1998).

A Rhoophilus loewi az ugyanazon az ágon elhelyezkedő négy, tölgy gubacsokban fejlődő cynipid inquilin génusz (Saphonecrus, Synergus, Synophrus és Ufo) testvér csoportja. Ennek a törzsfejlődési ágnak a helyzete lehetővé teszi kétféle alternatív evolúciós hipotézis felállítását is. Az első szerint a Rhoophilus loewi az egyetlen ismert túlélője lehet az inquilinek egy hajdan volt sokkal diverzebb, bazális helyzetü törzsfejlődési ágának. Erre az ágra jellemző lehetett, hogy tagjai olyan gubacsdarazsakhoz is asszociálódhattak amelyek a tölgyeken kívül más gazdanövényekhez is társultak. Valamilyen oknál fogva a tölgyfákhoz kapcsolódó cynipid inquilinek különösen sikeres leszármazási vonalát képviselik ennek a csoportnak. A másik elmélet szerint a Rhoophilus génusz önmagában az ösi törzsfejlődési vonalnak egy olyan délafrikai oldalágát képezi amely az ökológiai tulajdonságai és gazdanövény kapcsolatai alapján a lehető legközelebbi rokonságban áll a tölgyekhez kötődő cynipid inquilin génuszokkal (van Noort és mtsi 2007).

A Synophrus-Saphonecrus-Synergus leszármazási sort Melika (2006) négy alcsoportra osztotta (8. ábra): a) „Synergus”- ide tartozik a Synergus fajok többsége. A NyugatPaleartikumban élő fajainak döntő többsége a Quercus génusz Quercus szekciójához társul de van néhány faja a régióban amely a Cerris szekcióhoz asszociálódott.; b) a ,flavipes” csoport néhány Nyugat Palearktikus Synergus fajt sorolunk ide, melyek a Cerris szekcióhoz kötődnek; c) a „,haimi” csoport - 3 Saphonecrus faj tartozik ide (S. undulatus (Mayr, 1872), S. haimi (Mayr, 1872) és S. irani (Melika \& Pujade-Villar, 2006), melyek szintén a Cerris szekcióhoz kötődnek és d) az előbbiek testvércsoportját képezi, egy feltehetően korán elkülönülő ágat képviselő „Synophrus” csoport, melyhez néhány Saphonecrus fajt ( S. gallaepomiformis, S. barbotini) is sorolunk (Melika,2006; Pénzes és mtsi 2009, Ács és mtsi, 2010).

Ufo fajok csak a Kelet-Palearktikumból és az Orientális régióból ismertek. A Saphonecrus és Synergus nemre jellemző morfológiai karakterek keverten fordulnak elő az Ufo génuszban (Melika és mtsi 2005). A közös karakterek alapján soroljuk az Ufo nemet az inquilin génuszok Synergus-komplexébe. A közelmúltban megjelent filogenetikai elemzések még nem tartalmazták a bizonytalan helyzetü Ufo génuszt (Ács és mtsi 2010). Filogenetikai kutatásainkba már a génusz fajait is bevontuk (Melika és mtsi 2012).

A fajok Synergus-komplexumán belül végzett legutóbbi filogenetikai elemzések támogatják a nagy fajszámú Synergus és a kisebb Synophrus génuszok monofiletikus jellegét míg a Saphonecrus génusz monofiletikusságát cáfolják (Pénzes és mtsi 2009, Ács és mtsi 2010). 
Ezeket az eredményeket támogatják azok a komplexumot érintő legújabb filogenetikai elemzések is amelyek dolgozatom tárgyát képezik.

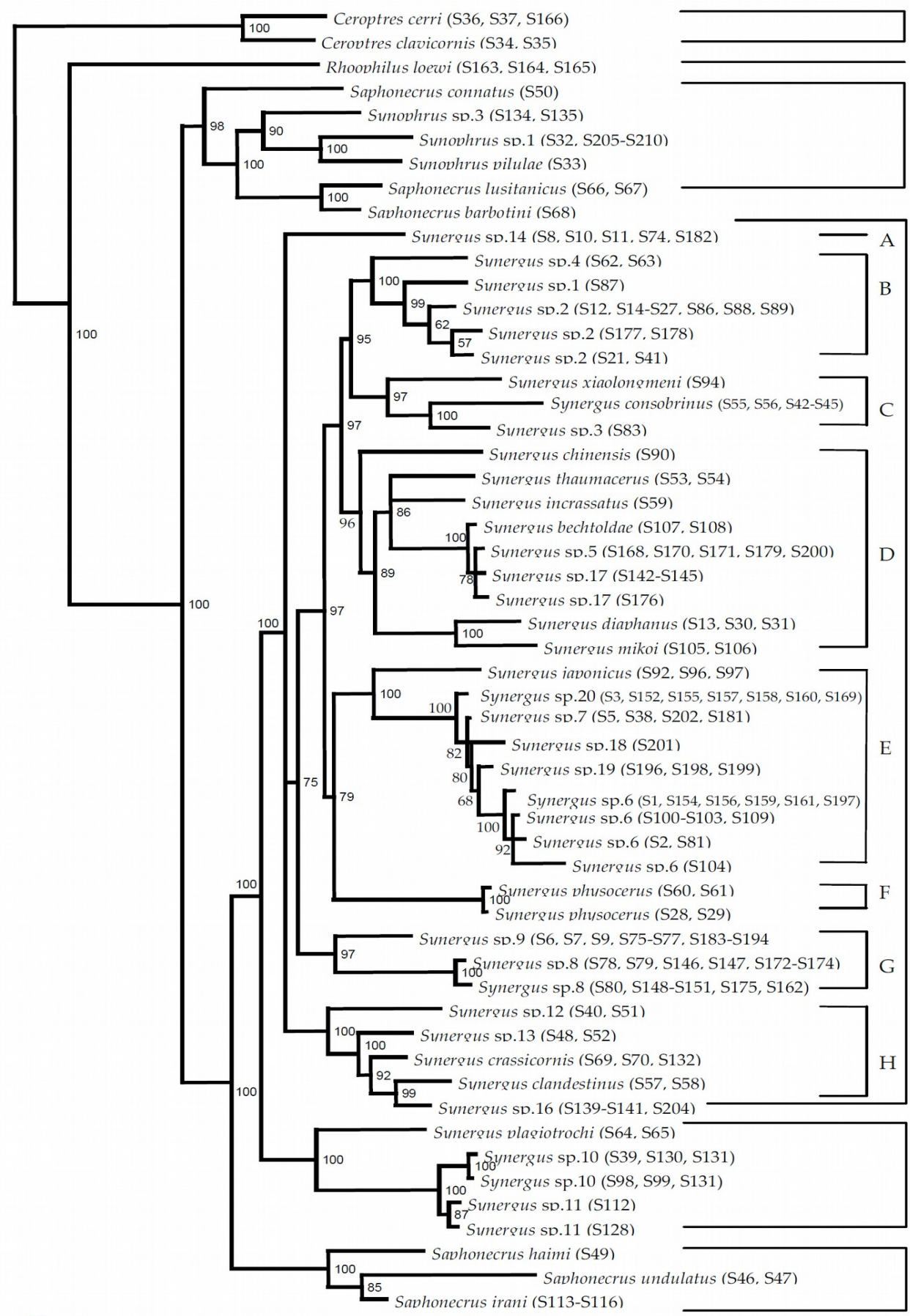

Ceroptres

Rhoophilus

4. Klád

(Synophrus)

1. Klád

(Synergus)

2. Klád

(Flavipes)

3. Klád

(Haimi)

8. ábra A Synergini tribus rokonsági viszonyait szemléltető Bayes alapú konszenzus fa COI, cytb és 28S D2 szekvenciák alapján. Melika (2006) nyomán. 


\section{Célkitüzések}

Munkámban célul tüztem ki a Synergus-komplexbe tartozó Saphonecrus és „Saphonecrusközeli” csoportok új rendszertanának felállítását, a csoport új génuszának - Lithosaphonecrus - a hozzá tartozó típus fajnak, illetve a génuszba sorolt négy új fajának a leírását és azonosítását. Célom volt, hogy igazoljam a Saphonecrus génusz filogenetikai vizsgálatának szükségességét, testvér csoportjainak azonosítását, a közelálló génuszokhoz (Ufo, Synophrus, Synergus) kötődő filogenetikai kapcsolatait és feltárjam a Saphonecrus-hoz tartozó fajok/fajcsoportok trofikai gazdaállat és gazdanövény - kapcsolatait. 


\section{Anyagok és módszerek}

\subsection{Mintavétel}

A vizsgálatban használt darázs egyedek 2008-2012 között Oroszország, Japán, Kína és Tajvan különböző régióiban frissen begyüjtött gubacsokból a következő módon lettek kinevelve: a terepen begyüjtött gubacsokat zárható müanyag zacskókba helyezték majd a kutatásban résztvevő laborok (University of Edinburgh (Egyesült Királyság), National Chung Hsing University (Taichuing, Tajvan)) egyikében helyezték el. Itt a gubacsokat szobahőmérsékleten olyan müanyag konténerekben tárolták amelyeknek a tetején négyzet alakú, hálóval fedett nyílást alakítottak ki annak érdekében, hogy a megfelelő szellőzésnek köszönhetően elkerüljék a gubacsok gombás fertőzését. A konténereket naponta ellenőrizték, a frissen kibújt kifejlett darazsakat további vizsgálatukig 96\%-os etanolban tárolták. A gubacsokat elhelyezkedésük alapján a következő kategóriákba soroltuk: a) csúcsrügyön vagy oldalrügyön található (rügygubacs); b) fiatal hajtáson található (szárgubacs); c) a levél föerén, a levélnyélen vagy a levélalapon található (levélgubacs); d) a hím virágzaton fejlődő (barkagubacs).

A begyüjtött mintákat táblázatban foglaltam össze, az eddig még leíratlan példányokat Saphonecrus sp. jelöléssel láttam el (függelék: II. táblázat). A DNS szekvenciák és az előzetes morfológiai eredmények alapján ezek egymástól egyértelmüen elkülöníthető egységeknek tekinthetőek. A Saphonecrus sp. 50. és 51. példányok kivételével - melyeket az Callirytis hakonensis (Ashmead) gubacsaiból neveltek ki - eddig még morfológiai és molekuláris elemzésekbe be nem vont új egyedek esetében a gubacsgazda fajok vagy ismeretlenek vagy eddig még nem kerültek leírásra. A molekuláris vizsgálatokba nem vettük be a Synerguskomplexbe tartozó Agastoroxenia génuszt mivel nem álltak rendelkezésre megfelelő példányokhoz.

\subsection{Molekuláris filogenetikai vizsgálatok}

Az ízeltlábúak körében DNS alapú filogenetikai vizsgálatokban a leggyakrabban használt régiók közé tartozik a mitokondriális citokróm c-oxidáz I alegység génje (COXI, COI) illetve a magi 28S riboszomális DNS D2 régiójának (28S D2) szekvenciája (Caterino és mtsi 2000). Mi is ezeket a markereket választottuk, mivel ezekkel volt lehetőségünk eredményeinket mások eredményeivel összevetni.

A gubacsdarázs-alkatúak között bevált módon, a kifejlett példányok 1-1 lábából az irodalomból ismert chelex protokollt követve vontuk ki a DNS-t (Nicholls és mtsi 2010). A mitokondriális citokróm-oxidáz I gén 658 bázispárnyi szakaszát az általánosan használt HCO-2198 (5’ TAA ACT TCA GGG TGA CCA AAA AAT CA 3’) és LCO-1490 (5’GGT CAA CAA ATC 
ATA AAG ATA TTG G 3') primerek (Folmer és mtsi 1994), míg a magi 28S riboszomális gén variábilis D2 régiójának 565 bázispárnyi fragmentjét a D2F (5'-CGTGTTGCTTGATAGTGCAG C-3') és D2R (5'-TCAAGACGGGTCCTGAAAGT-3') primerek (Hancock és mtsi 1988) alkalmazásával, polimeráz láncreakció (PCR) során szaporítottuk fel. A PCR reakciókat $25 \mu 1$ végtérfogatban végeztük $2 \mu$ templát DNS-t, 2,5 $\mu 1$ 10X Taq puffert (Fermentas), $2 \mu \mathrm{lMgCl2-t}$ (25 mM, Fermentas), 0,5 $\mu \mathrm{l}$ dNTP-t (10 mM, Fermentas), 0,5-0,5 $\mu 1$ primert (20 pM), 0,25 $\mu 1$ Taq polimerázt ( $5 \mathrm{u} / \mu \mathrm{l}$, Fermentas) és $16,75 \mu \mathrm{l}$ desztillált vizet felhasználva. A PCR reakciókat egy PTC-200 DNA Engine (MJ Research) készüléken végeztük a következő programok alapján: minden esetben az első lépés $94{ }^{\circ} \mathrm{C}$-on két percig tartott, majd ezt követte 35 ciklus az alábbiak szerint: $94{ }^{\circ} \mathrm{C} 30$ másodpercig, $50^{\circ} \mathrm{C}$ (COI esetében) illetve $45{ }^{\circ} \mathrm{C}$ (28S D2 esetében) 30 másodpercig majd $72{ }^{\circ} \mathrm{C} 45$ másodpercig, végül utolsó lépésben a mixet 10 percig $72{ }^{\circ} \mathrm{C}$-on tartottuk. A kapott PCR termékből $5 \mu$ l-t 1\%-os agaróz gélen elektroforetizálva ellenőriztük a reakció sikerességét. A szekvenálásra szánt PCR terméket a gyártó utasításait követve Millipore Ultrafree-DA DNS extrakciós kittel nyertük vissza közvetlenül az agaróz gélből. A 28S D2 régióból felszaporított fragment esetében a tisztított PCR terméket mindkét irányból, a COI esetében forward irányból vagy szintén mindkét irányból megszekvenáltattuk (MWG-Biotech AG, http://www.mwg-biotech.com). A kromatogramokat a Staden Package 2.0.0 (Bonfield és mtsi 1995) programcsomaggal állítottuk össze. Az új haplotípusokat a GenBank adatbázisában hozzáférhetővé tettük (JX468358-JX468371, KC899795-KC899802, KF532091-KF532122, függelék: II. táblázat).

Elemzésünkbe Ács és mtsi (2010) korábbi tanulmányában szereplő egyéb Synergus és Synophrus fajok szekvenciáit is bevontuk így a végleges adatsorunk elemzéstől függően minimum 50 taxon szekvenciáit tartalmazta (függelék: II. táblázat). A Saphonecrus sp. 21 (Melika és mtsi 2012) taxon esetében a 28S D2 gén szekvenciánk a többi vizsgált egyedhez képest csak egy rövidebb fragmentje állt rendelkezésünkre.

\subsection{A szekvenciák elemzése}

A szekvenciákat Muscle 3.6 (Edgar 2004) szoftverrel, alapértelmezett beállításokkal illesztettük egymáshoz. A 619 bp hosszúságú COI szekvenciák illesztése egyértelmű volt. Az illesztés után a gerinctelen mitokondriális kódtábla alapján a szakasz nukleotid sorrendjét fehérjékre fordítottuk le annak érdekében, hogy ellenőrizni tudjuk valóban kódoló szakaszt szaporítottunk-e fel. A 28S gén D2 régiójának 596 bp hosszúságú illesztett szekvenciáiban a gap-eket manuálisan úgy illesztettük, hogy kongruensek legyenek a már publikált Cynipini szekvenciákkal (Nylander és mtsi 2004). A szekvencia leíró statisztikákhoz és a genetikai távolságok számításához Mega 5 
szoftvert (Tamura és mtsi 2011) használtunk.

Filogenetikai rekonstrukciónk során az evolúciós modellek becslése a MrModeltest 2.3 (Nylander 2004b) programmal történt. Az adatokra legjobban illeszkedő modellek kiválasztásánál az AIC értékeket vettük figyelembe.

A filogenetikai becslést Bayes módszerrel végeztük a MrBayes 3.2.1 (Ronquist és mtsi 2012) szoftver segítségével. A particionált analízisben a COI szekvencia kodon pozícióit (1.2.,3. kodon pozíció) és a teljes 28S D2 szekvenciát különálló partíciókként értelmeztük amelyek tehát végeredményben négy adat partíciót eredményeztek. MCMC elemzésünk során az összes partíciónál a $\mathrm{GTR}+\mathrm{G}$ evolúciós modellt használtuk, valamint a partíciókra vonatkozó paramétereket (statefreq, revmat, shape) minden esetben egymástól függetlennek tekintettük. Minden egyéb priort alapértéken hagytunk.

Az analízis során a fák terének elemzésére két független futtatást végeztünk, egyenként 4 párhuzamosan futó lánccal. 10 millió generációig futtatva a Markov-láncok konvergenciája kielégítő volt (minden ezrediket mintáztuk), az első 40\%-ot burn-in-nek tekintettük. A futtatások split frekvenciáinak szórása 0.005 alatt maradt, illetve a PSRF (potential scale reduction factor) statisztika értéke minden esetben a 0.999-1.001 tartományban volt. A minimális effektív mintanagyság (ESS) meghaladta a 200-at. A kapott filogenetikai fát esetünkben fajfának tekintettük. Elemzésünkben a Ceroptres clavicornis Hartig fajt tekintettük külcsoportnak (Ács és mtsi 2010). Az analízisben szereplő mintákat a függelék II. táblázatában található kódokkal jelöltük.

\subsection{Morfológiai leírás}

$\mathrm{Az}$ inquilin darázs fajok morfológiájának leírása során a cynipidákkal foglalkozó tanulmányok (Melika 2006, Melika és mtsi 2010, Liljeblad és mtsi 2008) és a bevezetésben használt Hymenoptera Anatomy Ontology (HAO, Yoder és mtsi 2010) terminológiáját követtük. Az szárnyak erezetének rövidítései esetében Ronquist és Nordlander (1989), a kutikula felületi mintázatával kapcsolatos terminológia esetében pedig Harris (1979) munkáját vettük figyelembe. A vizsgált taxonok morfológiai leírására használt struktúrák a bevezetésben a Synergini tribus jellemzésénél, illetve a Lithosaphonecrus génusznak és fajainak jellemzésénél részletesen megtalálhatóak. A mért paramétereket a következőképpen rövidítettük:

- $\quad$ F1-F12: az 1. és az azt követő csáp flagellomerek mérete, alakja;

- POL (post-ocellar distance): a hátsó pontszemek belső szegélyei között mért távolság;

- $\quad$ OOL (ocellar-ocular distance): a hátsó pontszemek külső szegélye és az összetett szemek 
belső szegélye között mért távolság;

- $\quad$ LOL: Az oldalsó és a frontális pontszemek között mért távolság.

Az elülső szárny radiális sejtjének szélessége a szárny szegélye és az Rs ér között mért hossznak felelt meg.

A dolgozatban szereplö, a darazsak anatómiáját szemléltető fotók Leica DMLB sztereomikroszkópra rögzített Nikon Coolpix 4500 digitális fényképezőgéppel készültek, majd a rétegeket CombineZP (Alan Hadley) szoftverrel illesztettük egymáshoz. A fotók további szerkesztéséhez az Adobe Photoshop 6.0 programot használtuk.

A vizsgálatban felhasznált típus anyagok a következő intézmények gyüjteményeiben találhatóak meg: NMNS, National Museum of Natural Science, Taichung, Tajvan (kurátor MingLuen Jeng); Nemzeti Élelmiszerlánc-biztonsági Hivatal, Növény-egészségügyi és Molekuláris Biológiai Laboratórium, Budapest, Magyarország (kurátor Dr. Melika George); NCHU, Department of Entomology, National Chung Hsing University, Taichung, Tajvan (kurátor ChangTi Tang); USNM, U.S. National Museum of Natural History, Smithsonian Institution, Washington, DC, U.S.A. (kurátor M. Buffington); BLKU, Biosystematics Laboratory, Graduate School of Social and Cultural Studies, Kyushu University, Fukuoka, Japán (kurátor Y. Abe). 


\section{Eredmények}

\subsection{A molekuláris filogenetikai és morfológiai elemzések kombinált eredményei}

Elemzésünkbe 55 taxon adatait vontuk be (függelék: II táblázat). Saját mintáink szekvenciáit a 28S D2 szakasz elemzésében 23 haplotípusba (9.ábra), a coxI szakasz esetében 32 haplotípusba (10.ábra) tudtuk csoportosítani. A Saphonecrus irani és a 25-ös Saphonecrus példány esetében csak a magi szekvenciák álltak rendelkezésre ezért ezeket az egyedeket kihagytuk a végső filogenetikai rekonstrukciónkból amely a összesen 1215 bp-nyi szekvenciáján alapult. A kombinált konszenzus fát alkotó 53 haplotípus filogenetikai kapcsolatának vizsgálata (11.ábra), valamint a Saphonecrus és Saphonecrus-közeli kládokhoz köthető egyedek morfológiai elemzése során előzetes várakozásunknak megfelelően ismét igazolni tudtuk, hogy a Synergus és Synophrus génuszokkal ellentétben sem a molekuláris, sem a morfológiai adatok nem támasztják alá, hogy a vizsgálatunkba bevont Saphonecrus fajok együttese monofiletikus csoport lenne. A továbbiakban a kombinált fa alapján áttekintem a föbb csoportokat, röviden összefoglalom a rájuk jellemző főbb morfológiai karakter állapotokat.

Munkánk eredményeként három fő kládot, azon belül is nyolc Saphonecrus leszármazási sort tudtunk elkülöníteni. melyek poszteriori valószínüsége minden esetben meghaladta a 0,68-ot (11.ábra). Ezek egyikének, a Synophrus fajokhoz társuló „barbotini” kládnak (amely a $S$. barbotini és S. gallaepomiformis mediterrán fajokat tartalmazza) támogatottsága (poszteriori valószínűség 0,72) minden korábbi elemzéshez hasonlóan ( Pénzes és mtsi 2009, Ács és mtsi 2010) arra utal, hogy ez a Synophrus fajokhoz áll legközelebb. A Saphonecrus gallaepomiformis és S. barbotini az összes ismert Synophrus fajjal közösen képez egy monofiletikus csoportot (Pénzes és mtsai 2009, Ács és mtsai 2010) amelyen belül az elemzésünkbe bevont $3 \mathrm{db}$ NyugatPalaearktikus fajával a Synophrus génusz egy elkülönülő monofiletikus leszármazási vonalat képez. A Saphonecrus génuszhoz hasonlóan a Synophrus génusz fajainál is hiányoznak az oldalsó frontális barázdák (lateral frontal carinae) és az első szárny radiális sejtje is nyitott. A Synophrus génusznál azonban a pronotum laterális barázdája hiányzik, a pronotum háti irányból nézve lekerekített és a hímeknek 13 csápflagellomere van. Ezzel szemben a Saphonecrus génusznál a pronotum laterális barázdája megfigyelhető, a pronotumon háti irányból nézve élesebb sarkok láthatóak, és a hímeknek csak 12 flagellomere van. 


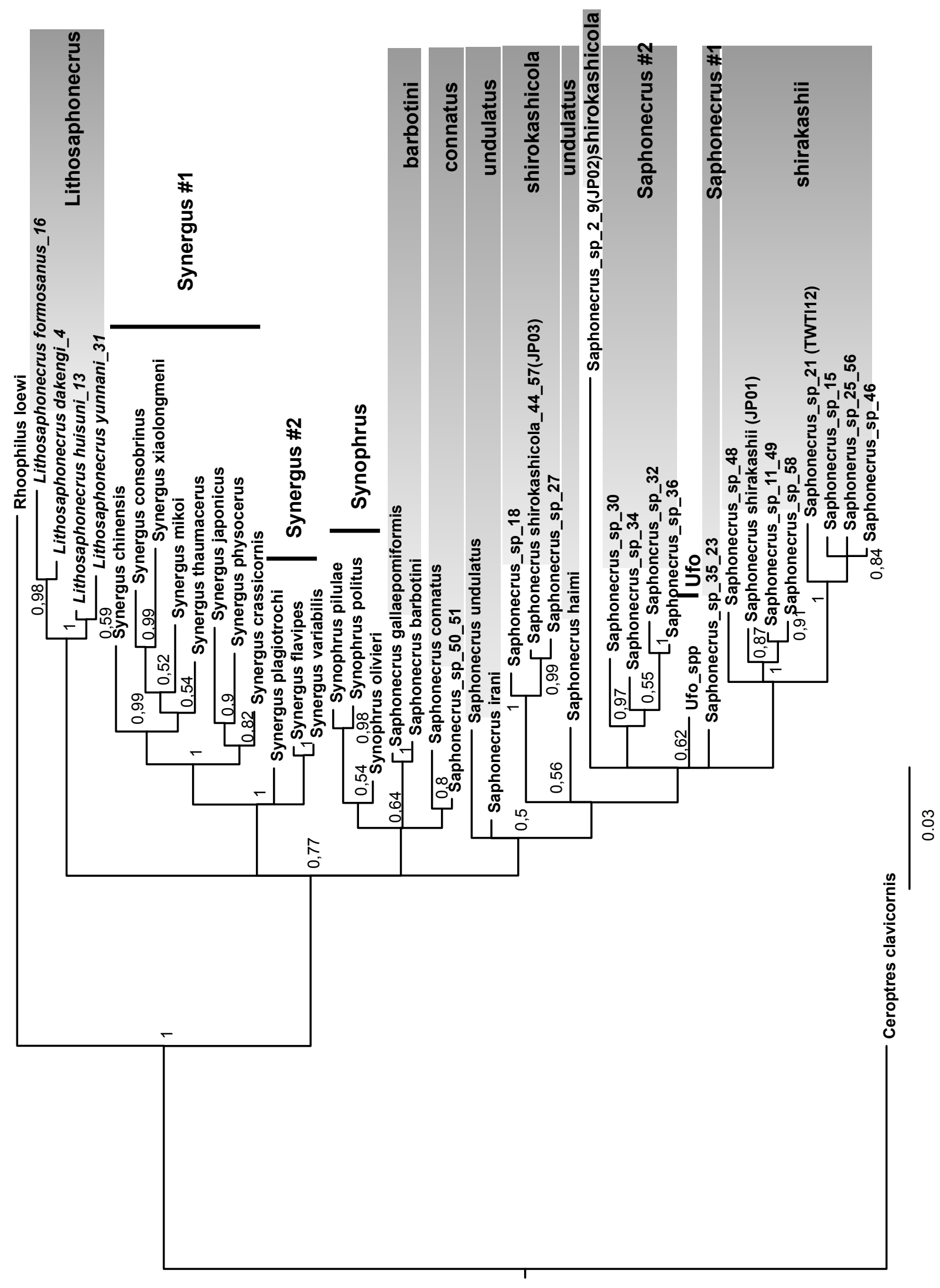

9. ábra: A Synergus-komplex vizsgált tagjainak 28S D2 alapú filogenetikája. 50\% majority-rule konszenzus fa, amely Bayes analízissel, a partícionált adatok alapján készült. Külcsoportnak a Ceroptres clavicornis fajt tekintettük. Az ábrán szürke színnel a Saphonecrus és Saphonecrusközeli kládokat jelöltük. Az elágazási pontok mellett a posteriori valószínüség értékekeit tüntettük fel. 


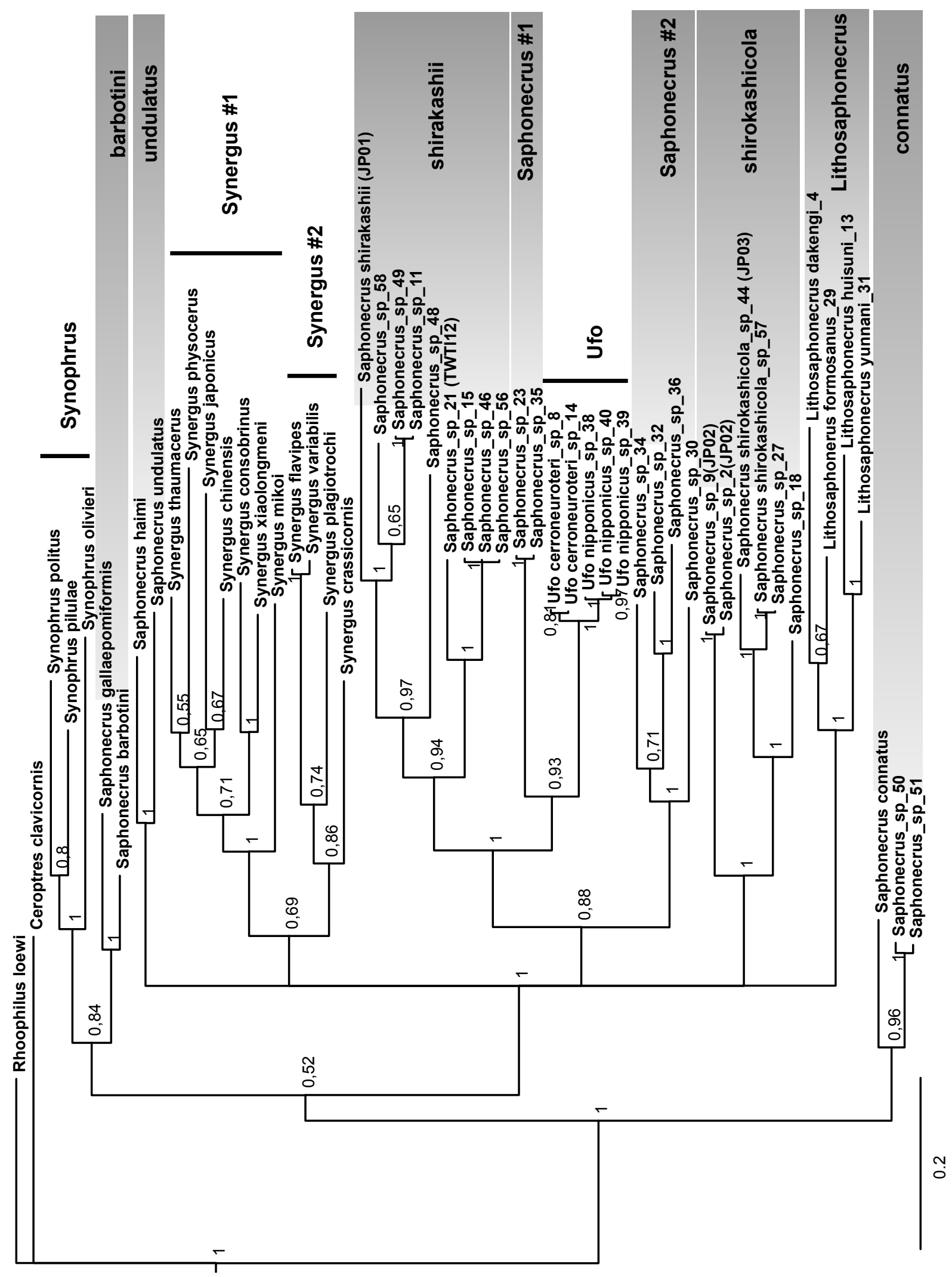

10. ábra: A Synergus-komplex vizsgált tagjainak citokróm oxidáz I alapú filogenetikája. 50\% majority-rule konszenzus fa, amely Bayes analízissel, a partícionált adatok alapján készült. Külcsoportnak a Ceroptres clavicornis fajt tekintettük. Az ábrán szürke színnel a Saphonecrus és Saphonecrus-közeli kládokat jelöltük. Az elágazási pontok mellett a posteriori valószínüség értékekeit tüntettük fel. 


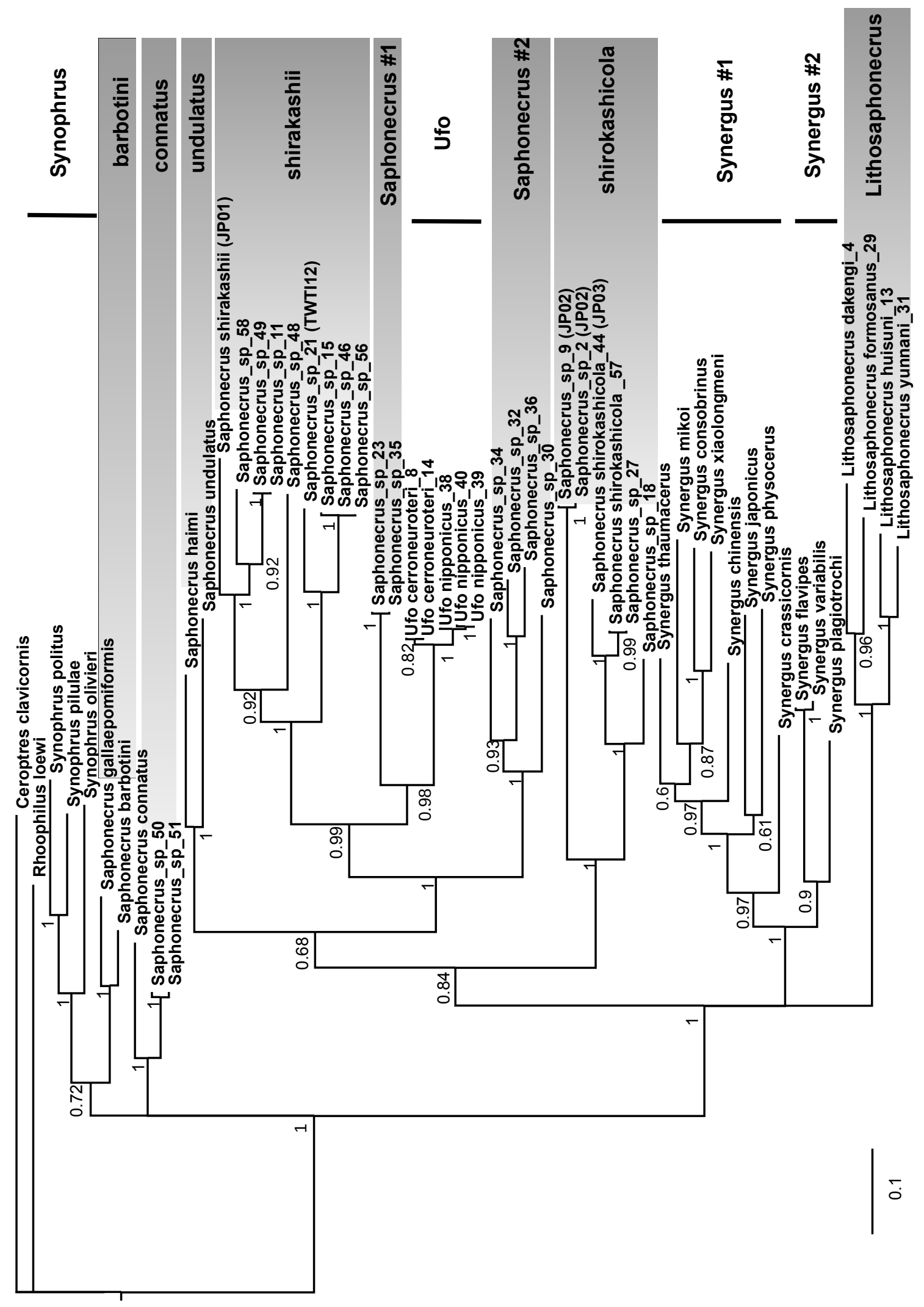

11. ábra: A Synergus-komplex vizsgált tagjainak rokonsági viszonyait szemléltető kombinált $50 \%$ majority-rule konszenzus fa, amely Bayes analízissel, a COI és 28S D2 partícionált adatok alapján készült. Külcsoportnak a Ceroptres clavicornis fajt tekintettük. Az ábrán szürke színnel a Saphonecrus és Saphonecrus-közeli kládokat jelöltük. Az elágazási pontok mellett a posteriori valószínség értékekeit tüntettük fel. 
A Synophrus génusszal közösen fent említett két Saphonecrus fajhoz társítható föbb jellemzők a következők: (1.) a pronotum oldalsó barázdája hiányzik, a pronotum dorzális nézetből lekerekített és (2.) a hímeknek csápjai 13 flagellomerrel rendlkeznek. Ezek alapján az említett két fajt át kellene helyezni a Synophrus nembe. Azonban néhány biológiai, elterjedésbeli sajátosságuk, gazdanövény és gazdagubacs kapcsolataik, valamint egyes morfológiai karakterállapotaik (például a fej és a utótest formája, a mesoscutum mintázata, a notauli hossza) arra utalnak, hogy értelmezhetőbb lenne ha egy külön nembe lennének csoportosítva. Ennek megerösítésére azonban alaposabb filogenetikai elemzésre van szükség.

A „connatus” klád a Nyugat-palearktikumi Saphonecrus connatus mellett még két leírás alatt lévő Kelet-Palearktikus fajt is tartalmazott (Saphonecrus sp. 50-51) (11.ábra). A Saphonecrus connatus helyzete - mivel ez a Saphonecrus génusz típus faja - alapvető jelentőségü a taxon státuszának meghatározásában. A $S$. connatus-t is magában foglaló „connatus” leszármazási vonal osztozik a Saphonecrus barbotini, S. gallaepomiformis és Synophrus fajok esetében imént leírt két szünapomorfiában (lateral frontal carinae hiánya és az elülső szárny nyitott radiális sejtje). Eredményeink egybevágnak az eddigi molekuláris adatokkal melyek néhány morfológiai sajátossággal kiegészítve azt sugallják, hogy ebben az esetben egy a fajkomplexen belül korán szeparálódott egyértelmüen elkülöníthető, a „,barbotini” kládtól is eltérő taxonómiai egységről beszélhetünk. Azonban a $S$. connatus-nak és kapcsolódó fajainak helyzete a molekuláris filogenetikában is bizonytalan (11.ábra).

A vizsgálatunkban bevont többi Nyugat-Palearktikus Saphonecrus faj abba a nagy kládba ágyazódik be amely tartalmazza a további vizsgált Kelet-Palearktikus Saphonecrus csoportokat, az Ufo génuszt és a Nyugat- és Kelet-Palearktikus fajokat egyaránt magában foglaló Synergus kládot (11. ábra). Azonban ezen a nagy kládon belül nem tudtuk megbízhatóan megbecsülni a Nyugat-Palearktikus Saphonecrus haimi, S. undulatus és feltételezhetően a S. irani fajokból álló „undulatus” szubklád testvér csoportját (sister group). Valamint a kládon belüli fő leszármazási vonalak között fennálló kapcsolatok sem teljesen világosak. A Synergus fajok, illetve az ázsiai Lithocarpus fajokhoz asszociálódott Lithosaphonecrus vonal egy-egy jól elkülöníthető egységet képviselnek (poszteriori valószínüség: 1). Azonban a Synergus génusz monofiletikus eredetével kapcsolatban fontos azt leszögeznünk, hogy ezekbe az elemzésekbe csak a Nyugat- és KeletPalearktikus fajok voltak bevonva. A Nearktikus és neotrópusi fajokról nem állnak rendelkezésre szekvenciák így a génusz teljes fajkészletének monofiletikus eredetét fenntartással kell kezelni. A Synergus-okat két csoportra tudtuk osztani („Synergus\#1” és „Synergus\#2”). Ács és mtsi (2010) arra utalnak, hogy a Synergus génusz Palearktikus fajai monofiletikus csoportot alkotnak, 
valamint hogy a Kelet-Palearktikus S. chinensis, S. xiaolongmeni és S. japonicus fajok a NyugatPalearktkus fajok közé beágyazódnak vagyis a Kelet- és Nyugat-Palearktikus Synergus fajok radiációja nem tekinthető egymástól függetlennek. Ez esetünkben is megfigyelhető volt, az említett három faj a „Synergus\#1” kládon belül szóródott a Nyugat-Palearktikus fajok között (11. ábra). A „Synergus\#2” csoport azt a 3 Nyugat-Palearktikus fajt foglalta magában (S. flavipes, $S$. variabilis, S. plagiotrochi) amelyek egyértelmüen a Cerris tölgyszekcióhoz társíthatóak. Ezzel szemben a „Synergus\#1” csoportban azok a fajok találhatóak amelyek a Quercus tölgyszekciót részesítik előnyben. A „Synergus\#2” klád 3 faja két közös morfológiai sajátosságot hordoz: esetükben mind a lateral pronotal- és lateral frontal carinae hiányzik. Ezzel ellentétben a „Synergus\#1” szubklád fajain - a S. consobrinus faj kivételével - jól látható a lateral pronotal- és lateral frontal carinae. Az említett S. consobrinus esetében a „Synergus\#2” klád fajaihoz hasonlóan szintén hiányoznak ezek a bélyegek. Ennek következtében a két csoportot a fajok morfológiája alapján nehéz egymástól elkülöníteni.

A „Lithosaphnecrus” csoport kizárólag a Lithocarpus tölgyszekcióhoz társuló fajai a többi „Saphonecrus” kládtól nagyon eltérő, egyedi morfológiai tulajdonságokkal rendelkeznek: lekerekített fejükön erős frontal carinae látható, a scutellar foveae-n erős ráncok vannak és a utótestük pontozott. A haplotípusok között páronként számított genetikai távolságok elemzése során (Bozsó és mtsi 2013) megállapítottuk, hogy ebben az esetben a csoporton belüli változatosság mértéke mind a coxI szekvenciák mind a sokkal konzervatívabb 28S D2 szekvenciák esetében kisebbnek bizonyult az elemzésbe bevont csoportok között tapasztalt változatosságnál. Ezért a csoportot alkotó, általunk vizsgált 4 egyedet a továbbiakban egy új génusz (Lithosaphonecrus) önálló fajainak tekintettük. A génusz és a fajok részletes jellemzésére a fejezet végén kerül sor.

A nyugati Saphonecrus fajok harmadik szubkládját a korábban „undulatus”-ként ismert csoport képezi (Pénzes és mtsi 2009, Ács és mtsi 2010) (11. ábra). Nem csak molekuláris bizonyítékokkal hanem például a következő morfológiai szünapomorfiákkal is alátámaszthatjuk, hogy ez a csoport nagyon távol esik a „,barbotini” és „connatus” kládoktól: a fej alakja és mintázata, a propodeum erős laterális barázdájának jelenléte, a notauli hiánya, nagyon rövid mesoscutum. Összhangban a molekuláris filogenetiai eredményekkel, az Ufo nemzetséget is beleértve az összes többi Saphonecrus klád hordozza az „undulatus” csoport morfológiai sajátosságait és így eltérnek a „connatus” és „barbotini” csoportoktól, valamint a Synophrus génusztól.

A közelmúltban két Andricus Hartig fajt áthelyeztek az Ufo génuszba és Ufo shirakashii (Shinji) valamint U. shirokashicola (Shinji) néven újra leírták őket (Wachi és mtsi 2011). 
Azonban ezt a két fajt tévesen helyezték át az $U f o$ nembe. Véleményünk szerint a fenti szerzők által megadott morfológiai karakterek alapján a két faj sokkal inkább hasonlít a Saphonecrus mint az Ufo fajokra. Az Ufo, Synergus és Saphonecrus taxonokra jellemző morfológiai sajátosságokat röviden összefoglaltuk korábbi cikkünkben (Melika és mtsi 2012). A Cyclobalanopsis tölgy szubgénuszán fejlődő fent említett két Saphonecrus faj a következőképpen jellemezhető: frontális irányból ovális vagy négyszögletes fejjel rendelkeznek (12/a, 12/e, 14/a ábrák); a homlok sima és fényes vagy bőrszerü, esetleg nagyon kevés elmosódott stria lehet még rajta (12/b, 12/f, 14/b ábrák); hímek esetében a csáp F1 íze csak kissé hosszabb az F2 íznél, maximum annak 1,5-szerese (12/i ábra); a mesoscutum finoman börszerü vagy pontozott, rajta keresztirányú striák nem láthatóak (13/c, 15/ ábrák). A S. shirakasii esetében a pedicel hossza 2,2-szerese a szélességének (12/h-i ábrák); nőstényeinél a csáp F1 ízének hossza 1,2szerese az F2 hosszának; az F11 hossza pedig 1,9-szerese az F10 hosszának (12/h ábra); notauli határozottan besüllyedtek és teljes hosszukban láthatóak, elérik a pronotumot. A $S$. shirokashicola-nál pedig a pedicel hossza 1,6-szerese a szélességének; nőstényeinél a csáp F1 ízének hossza 1,7-szerese az F2 íz hosszának; az F11 íz hossza pedig 2,3-szerese az F10 íz hosszának (14/d ábra); notauli kevésbé süllyednek be és rövidebb lefutásúak, csak a mesoscutum poszteriori $1 / 3^{-}{ }^{1} / 2$-ben láthatóak (15/b ábra). Frontális irányból tekintve a középtestük soha nem tűnik annyira négyszögletesnek mint az Ufo fajok esetében (Pénzes és mtsi 2009, Ács és mtsi 2010).

A ,shirakashii” klád az Ufo génusz, valamint a „Saphonecrus\#1” csoport testvér kládja (11. ábra). A „shirakashii” leszármazási vonalra jellemző morfológiai bélyegek: a mesoscutumon minden esetben rövid keresztirányú striák láthatóak melyek között a felszín sima, fényes; a fej szemböl négyszögletes, erőteljesebb; a nőstények metasomája hosszúkásabb. Eredményeink alapján ezt a kládot is legalább további kettő vagy három leszármazási vonalra tudjuk bontani (a) S. shirakashii + 58-as, 49-es és 11-es példány; b) 48-as példány; c) 21-es, 15-ös, 46-os, 56-os példányok), ebben az esetben sem zárhatjuk ki újabb fajok azonosításának lehetőségét.

A ,shirokashicola” kládot 0,84 -os poszteriori valószínüségi támogatottság mellett az Ufo génuszból és a Saphonecrus kládokból (,undulatus”, „shirakashii”, Saphonecrus\#1”, „Saphonecrus\#2”) álló csoport testvér kládjának tekinthetjük, melyet további két ágra tudunk osztani. A Japánból származó 2-es és 9-es darazsak szekvenciái a klád többi példányától egyértelmüen elkülönülő csoportot alkotnak, ebben az esetben sem zárhatjuk ki annak lehetőségét, hogy egy eddig még leíratlan új fajnak a képviselőit sikerült azonosítanunk (11. ábra). A fajok átsorolásával foglalkozó korábbi cikkünkben (Melika és mtsi 2012) a jelen dolgozatban használtakkal megegyező szekvenciák vizsgálata során a genetikai távolságok 
alapján arra a következtetésre jutottunk, hogy a $S$. shirakashii és a $S$. shirokashicola esetében olyan különálló taxonómiai egységekről van szó amelyek jelentősen eltérnek mind egymástól mind az Ufo génusztól ( Melika és mtsi 2012).

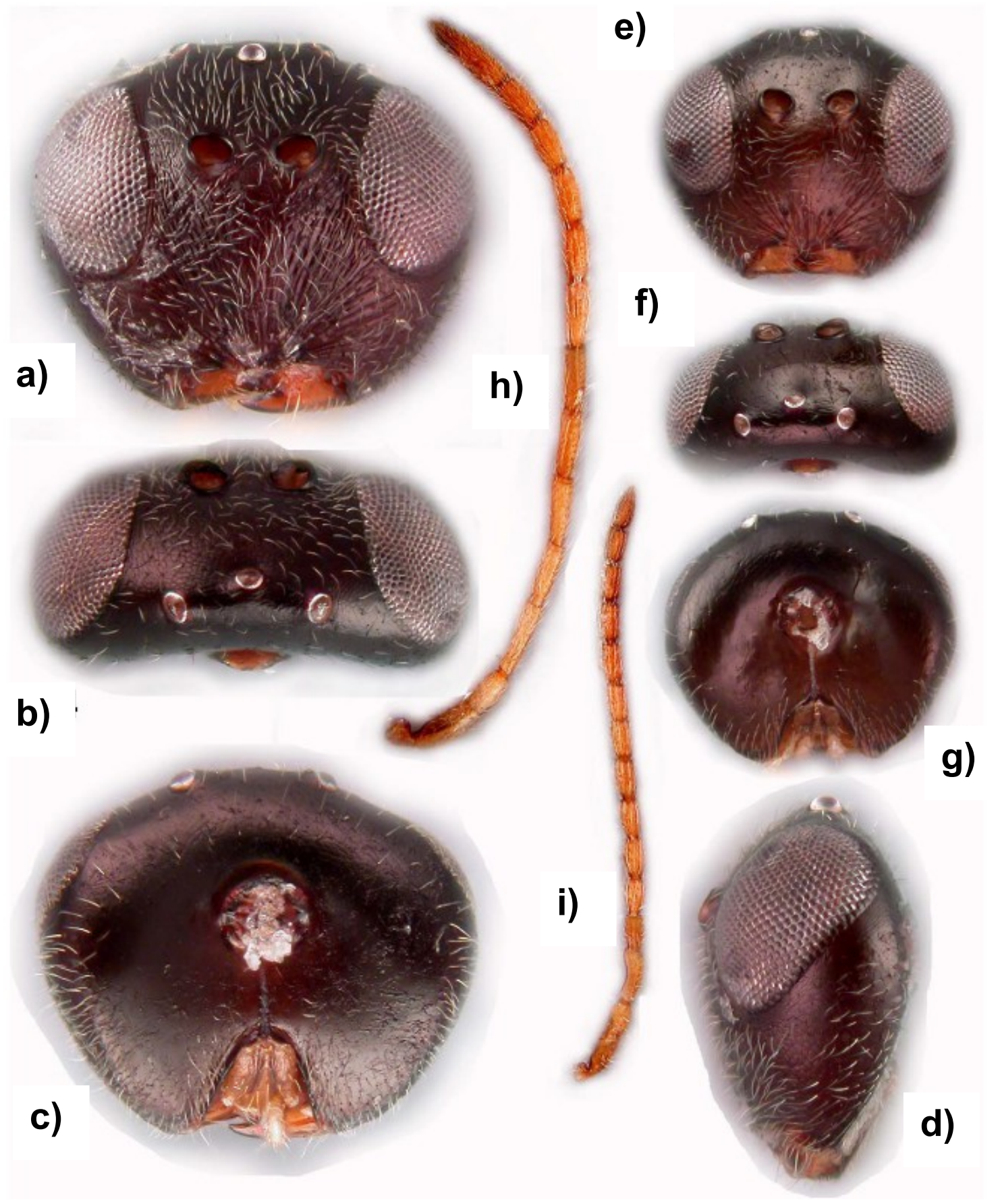

12. ábra: Saphonecrus shirakashii (Shinji): a)-d) nőstény példány feje: a) frontális irányból, b) dorzális irányból, c) poszterior irányból, d) laterális irányból; e)-g) hím példány feje: e) frontális irányból, f) dorzális irányból, g) poszterior irányból; h)-i) csápok: h) nőstény, i) hím. 

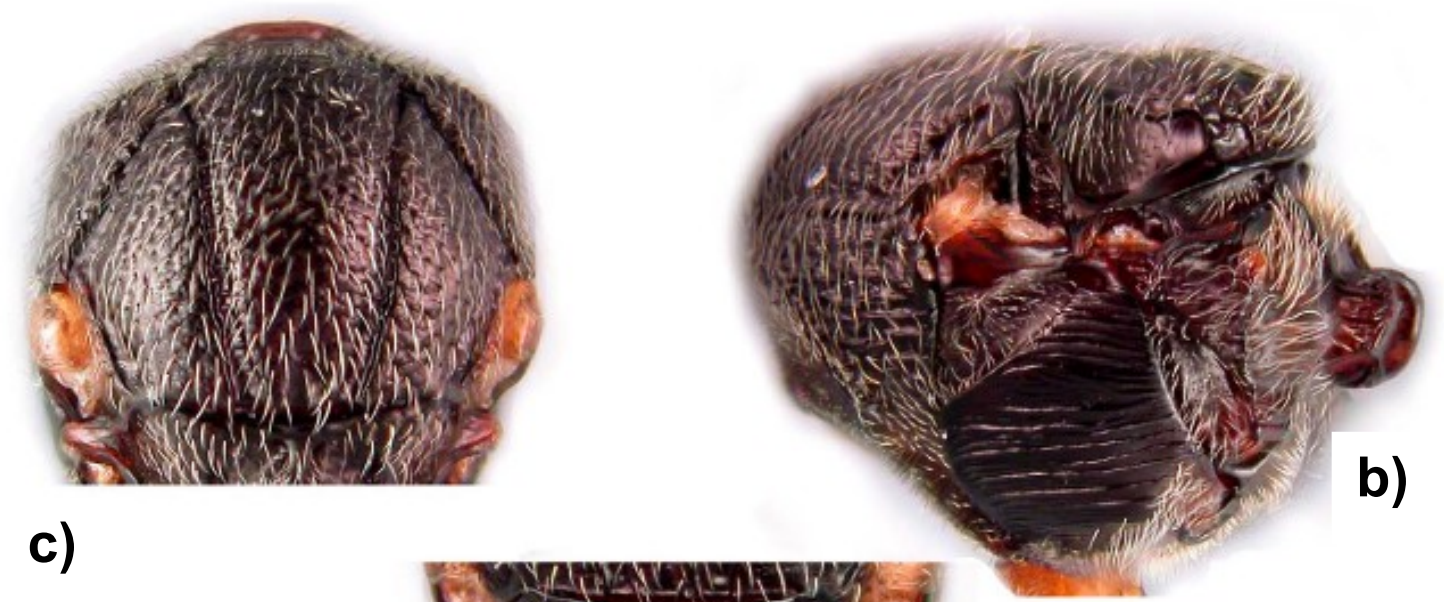

c)

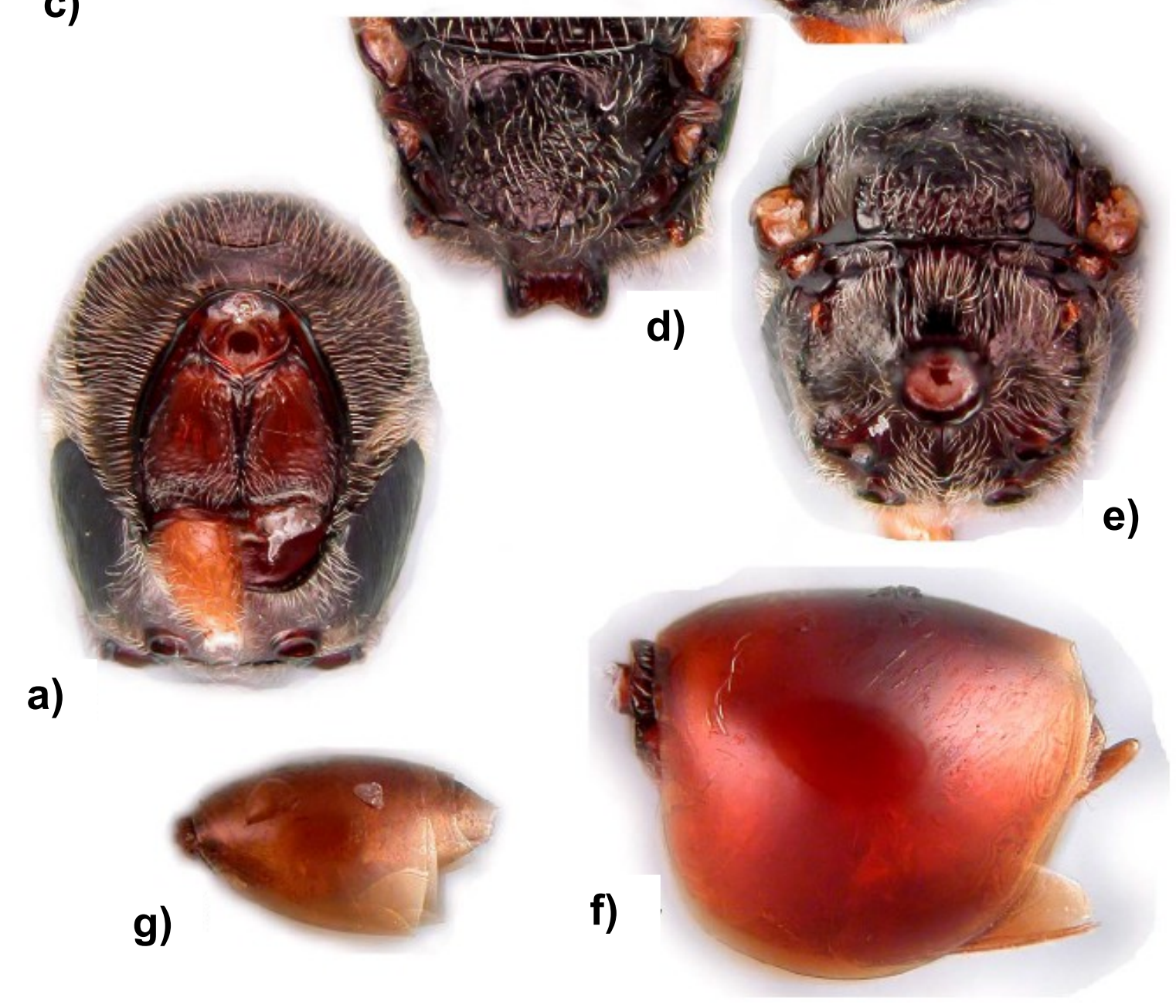

13. ábra: Saphonecrus shirakashii (Shinji): a)-f) nőstény példány: a) pronotum és propleuron frontális irányból, b) mesosoma laterális irányból, c) mesoscutum dorzális irányból, d) mesoscutellum dorzális irányból, e) metascutellum és propodeum poszterodorzális irányból, f) metasoma laterális irányból; g) hím metasoma laterális irányból. 


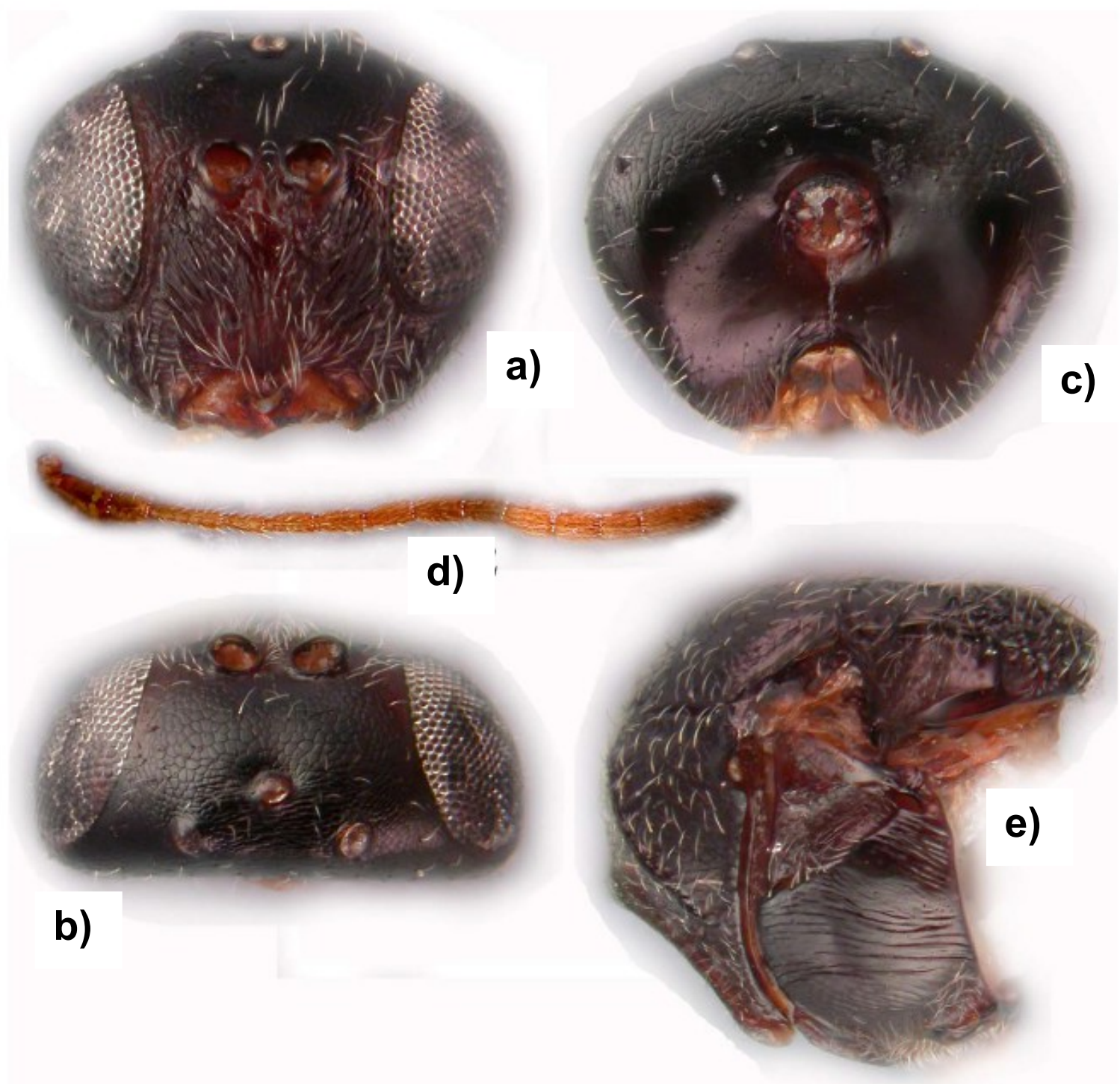

14. ábra: Saphonecrus shirokashicola (Shinji): a)-c) nőstény példány feje: a) frontális irányból, b) dorzális irányból, c) poszterior irányból; d) nőstény példány csápja; e) nőstény mesosoma részlet laterális irányból.

Az Ufo fajok szigorúan csak a Cerris tölgyszekcióhoz kötődnek és morfológiájuk is nagyon különleges. A génusz szünapomorf tulajdonságairól, valamint a génusz újonnan leírt két fajának morfológiai sajátosságairól a fenti fajokat leíró cikkünkben részletesen beszámoltunk (Melika és mtsi 2012). Mind az Ufo cerroneuroteri mind az U. nipponicus egyedei ugyanazzal a 28S D2 haplotípussal rendelkeztek és a genetikai távolságok elemzése alapján sokkal közelebb álltak a Saphonecrus irani-hoz mint akár a Saphonecrus shirakashii vagy a Saphonecrus shirokashicola fajokhoz (Melika és mtsi 2012)(9. ábra). A coxI szekvenciák nagyobb változatosságot mutattak, ebben az esetben minden Ufo példány egyedi haplotípussal rendelkezett (10. ábra). 

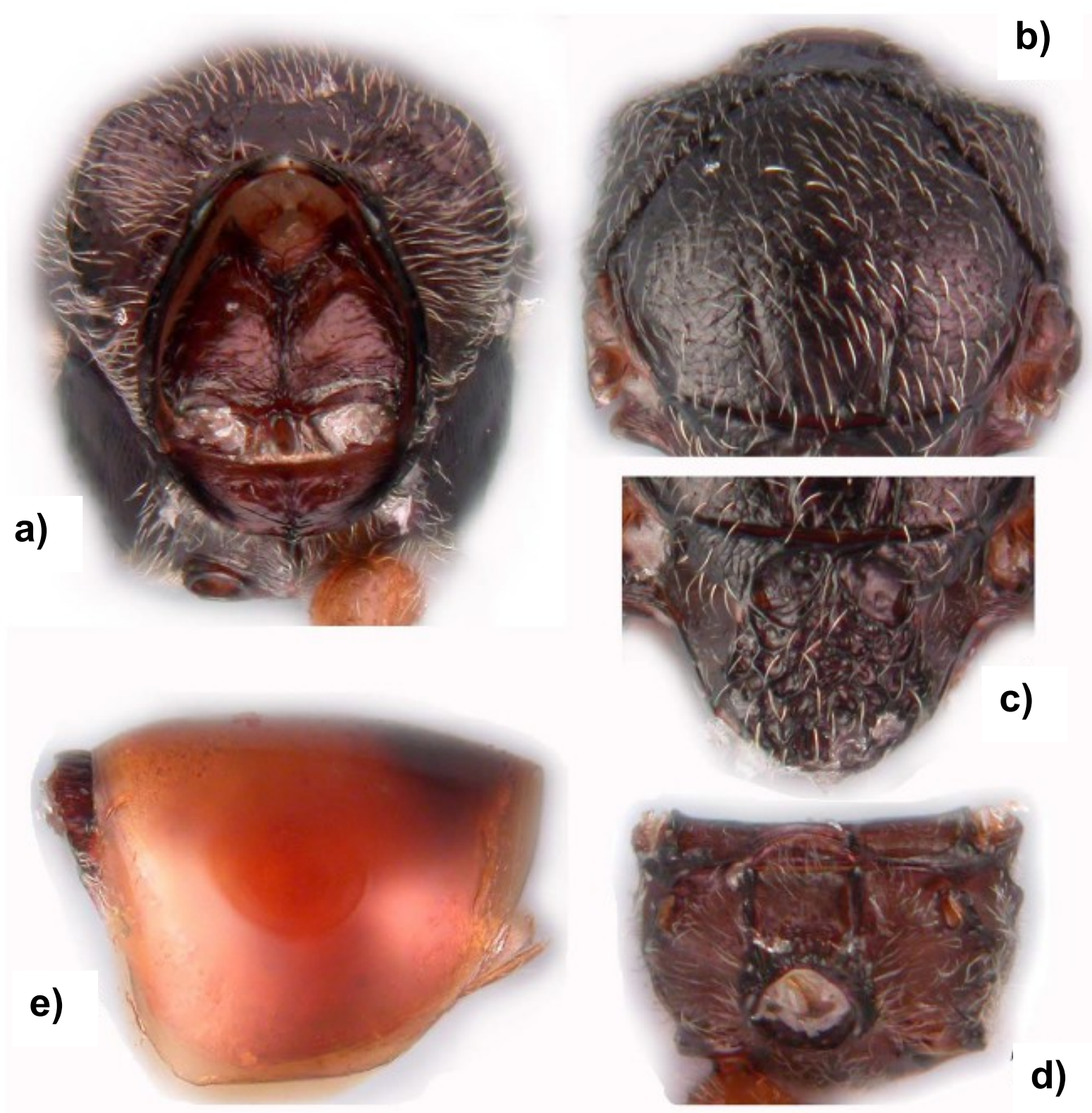

15. ábra: Saphonecrus shirokashicola (Shinji), nőstény példány: a) pronotum és propleuron frontális irányból, b) mesoscutum dorzális irányból, c) mesoscutellum dorzális irányból, d) metascutellum és propodeum poszterodorzális irányból, e) metasoma laterális irányból.

A „Saphonecrus\#1” esetében a mesoscutum finoman börszerü vagy pontozott, feltünő rövid és szabálytalan haránt irányú barázdák nélkül; a fej ovális és felülröl kevésbé robusztus; a nőstények metasomája lekerekítettebb. A „shirakashii” és „Saphonecrus\#1” csoportok minden fajáról ismert, hogy kizárólag a Quercus nemzetség Cyclobalanopsis alnemzetségéhez társulnak.

A „Saphonecrus \#2” kládról - amely testvér csoportja a „shirakashii” + „Saphonecrus \#1” + „Ufo” kládnak - ismert, hogy fajaik a Lithocarpus és a Quercus nemzetség Cyclobalanopsis alnemzetségéhez társíthatóak. A „Saphonecrus \#2” csoportba tartozó fajok nőstényeinél az arc alsó része és malar space egyenletesen barázdált, a barázdák a csápok tövéig elérnek; az összetett 
szemek magassága 1,9-szerese a malar space hosszának; a nyakszírt és a gena sima, fényes; a csápon a pedicel hossza 1,7-szerese a szélességének; a mesoscutum és mesoscutellum hossza megegyezik a középtest magasságával; scutellar foveae alja sima, fényes. Ezzel szemben a “ Saphonecrus \#1” csoport fajainak esetében ugyan a malar space barázdált azonban az arc alsó részének közepe barázdák nélküli, rajta csak oldalirányban láthatóak elmosódott barázdák és ezek nem érik el a csápok ízesülését; a nyakszirt és a gena egységesen bőrszerü; az összetett szem magassága 1,7-szerese a malar space hosszának; a csápon a pedicel hossza 2,5-szerese a szélességének; a mesoscutum és mesoscutellum hossza 1,2-szerese a középtest magasságának; scutellar foveae alja sima, fényes és rajta néhány ránc is látható. 


\subsection{A Lithosaphonecrus génusz részletes jellemzése (Bozsó és mtsi 2013):}

\section{Lithosaphonecrus Tang, Melika \& Bozsó}

Típusfaj: Lithosaphonecrus formosanus Melika \& Tang

Etimológia. A génusz neve a Lithocarpus nemzetséggel fennálló gazdanövény kapcsolatra és a Saphonecrus nemmel bizonyított rokoni kapcsolatra utal.

Diagnózis. Csak öt Kelet-Palearktikus Saphonecrus faj (S. shirakashii, S. shirokashicola, S. naiquanlini, S. yukawai, és S. excisus) rendelkezik az alábbi két, Lithosaphonecrus nemre is jellemző karakterrel: a nőstények csápja 11 flagellomerrel rendelkezikés és a pronotum laterális barázdája jelen van. Ugyanakkor a Lithosaphonecus fajok olyan, kizárólag a Lithocarpus nemzetség fajaihoz asszociálódott, morfológiailag is nagyon elkülönült csoportot alkotnak melyet az alábbi egyedi morfológiai karakterekkel jellemezhetünk: kerek vagy nagyon enyhén trapezoid robusztus fej, a toruli és a pontszemek között futó, szabálytalanul megszakadó frontális barázda, a mesopleuronon hálózatos striákkal rendelkezik; scutellar foveae összefolyó vagy elmosódott abban az esetben ha a középső carina is jelen van, fényes alján hosszanti párhuzamos erős ráncok figyelhetőek meg; az syntergite poszteriorális része pontozott vagy recézett, a mintázott sáv az összeolvadt tergitek hosszának legalább az $1 / 5^{-1} / 4$ részére kiterjed és mindig eléri a tergit ventrális szegélyét. Emellett a Lithosaphonecrus nőstények csápján az F1 hossza 1,5-1,9szerese az F2 hosszának, az F11 kétszerese az F10-nek, valamint hímek csápján az F1 hossza 2,6-3,0-szorosa az F2 hosszának. Eközben a fent említett Saphonecrus fajok esetében mindkét nemnél az F1 hossza 1,1-1,4-szerese az F2 hosszának és a nőstényeknél az F10, valamint az F11 hossza közel azonos. Ezen kívül az említett Saphonecrus fajoknál a homlok mindig sima vagy bőrszerü és fényes, soha nem található meg rajta a Lithosaphonecrus fajokra jellemző barázda, illetve az utótest egyesült 2. és 3. tergitjének poszterior sávja nem pontozott vagy recézett; ha elmosódottan jelen is van a pontozottság akkor az csak anteroposzterior helyzetü folt formájában jelenik meg, a mikroméretű pontozottság sohasem éri el a tergitek ventrális szegélyét.

Megjegyzések. A Weld által (1926) leírt, a Fülöp-szigetekről ismert egyik Saphonecrus faj ( $S$. serratus) annyiban hasonlít a Lithosaphonecrus génusz tagjaihoz, hogy a párhuzamos barázdák a homlokon jelen vannak, kiterjednek a vertexre és a pontszemek közti térre, elérik a toluli-t; az utótest összeolvadt 2. és 3. tergitjeinek poszteriorális részén mikropontozott sáv található; a lábtőkarmok szintén egyszerü, nem rendelkeznek bazális lebennyel. Azonban a továbbiakban felsorolt karakterek arra utalnak, hogy ezt a fajt talán nem is a Saphonecrus génusz tagjának kellene tekintenünk: a pronotum dorzálisan szokatlanul rövid (a Cynipini tribusra jellemző), a fej 
dorzálisan keresztirányú; a nőstények csápján 12 flagellomer látható; az elülső szárny radiális sejtje nyitott, a szárny szegélyén sürün álló hosszú sörték találhatóak; a laterális propodeal carina-k kifelé ívelnek, nem párhuzamosak; a hypopygium ventrális gerincének kiemelkedő része sokkal hosszabb mint ami általában a Saphonecrus génusz tagjainál megfigyelhető, hossza 3,5-4,0-szerese a szélességének. Tehát az eddigi tudásunk alapján azt nagy valószínüséggel kijelenthetjük, hogy ez a faj egy, a Saphonecrus génusztól egyértelmüen elkülöníthető csoport tagja.

A Saphonecrus areolatus Weld szintén egy Fülöp-szigetekről ismert faj (Weld 1926) a fent jellemzett társához hasonlóan szintén egyszerü, bazális lebeny nélküli lábtőkarmokkal rendelkezik. Azonban összes többi karakterében eltér a Lithosaphonecrus génusz tagjaitól.

A Saphonecrus excisus egy olyan Kelet-Palearktikus faj amelyet a Neuroterus haasi Kieffer által a Lithocarpus elegans (Blume) gazdanövényen indukált parányi, szárduzzanat-szerü gubacsaiból neveltek ki (Dalla Torre és Kieffer 1910). A kifejlett egyedek eredeti leírása szerint az itt jellemzett Lithosaphonecrus fajokhoz hasonlóan ebben az esetben is egyszerü, bazális lebeny nélküli lábtőkarmok jellemzik a fajt. Máskülönben megjelenésében az alábbi pontokban tér el a Lithosaphonecrus fajoktól: a nőstények csápjain az F1 és F2 hossza közel azonos, az F11 hossza 1,5-szerese az F10 hosszának; a mesopleuron sima és fényes, néhány hosszanti párhuzamos stria figyelhető meg rajta; felszínén soha nincsenek hálózatos striák; a syntergite poszteriorális részén nincs pontozottság.

\section{Lithosaphonecrus formosanus Melika \& Tang}

16-17. ábrák

Típus példány. HOLOTÍPUS nőstény: TAJVAN (TW346) Nantou megye, Dakeng: 5-1-es túraútvonal, Lithocarpus konishii-röl gyüjtött ismeretlen szárgubacsból kinevelve (nevelés kódja: spTWs5, gubacs típusa: A74), gubacsot gyüjtötték - 2008.10.21., leg. J. Nicholls. 49 nőstény és 16 hím paratípus: 2 nőstény: TAJVAN (TW26) Nantou megye, Huisun Forest Station, Lithocarpus glabra-ról gyüjtött ismeretlen barkagubacsból kinevelve (gubacs kódja: spTWc2, gubacs típusa: A96), gubacsot gyüjtötték-2008.10.25. leg. J. Nicholls; 1 nőstény és 1 hím: TAJVAN (TW103) Nantou megye, Huisun Forest St., Lithocarpus glabra-ról gyüjtött ismeretlen rügygubacsból kinevelve (gubacs kódja: spTWb72, gubacs típusa: A101), gubacsot gyüjtötték2008.10.25. leg. J. Nicholls; 14 nőstény és 4 hím: TAJVAN (TW105, TW106, TW107, TW109, TW111) Nantou megye, Huisun Forest St., Lithocarpus glabra-ról gyüjtött ismeretlen rügygubacsból kinevelve (gubacs kódja: spTWb7, gubacs típusa: A101), gubacsot gyüjtötték2008.10.25. leg. J. Nicholls; 2 nöstény és 2 hím: TAJVAN (TW277, TW278) Nantou megye, 
Dakeng:5-1-es túraútvonal, Lithocarpus konishii-ről gyüjtött ismeretlen rügygubacsból kinevelve (gubacs kódja: spTWb2, gubacs típusa: A76), gubacsot gyüjtötték-2008.10.21., J. Nicholls; 10 nőstény és 3 hím: TAJVAN (TW342, TW343, TW346, TW347) Nantou megye, Dakeng:5-1-es túraútvonal, Lithocarpus konishii-röl gyüjtött ismeretlen szárgubacsból kinevelve (gubacs kódja: spTWs5, gubacs típusa: A74), gubacsot gyüjtötték-2008.10.21., J. Nicholls; 10 nőstény és 3 hím: TAJVAN, Taichung megye, Taichung, Lithocarpus konishii-röl gyüjtött „tengerisün-szerü” gubacsból kinevelve (gubacs kódja: GA970319-3); 10 nőstény és 3 hím: TAJVAN, Nantou megye, Sunmoon-tó, Lithocarpus konishii-röl gyüjtött gubacsból kinevelve (gubacs kódja: GA990309-9).

A nőstény holotípust, 10 nőstény és 4 hím paratípust az NMNS, 15 nőstény és 4 paratípust a PHMB, 15 nőstény és 4 paratípust az NCHU, 6 nőstény és 4 hím paratípust az USNM gyüjteményeiben helyeztek el.

Egyéb példányok. 12 nőstény és 2 hím: TAJVAN, Taichung megye, Taichung, Lithocarpus konishii-ről gyüjtött „,tengerisün-szerü” gubacsból kinevelve (gubacs kódja: GA970319-3); 15 nőstény és 4 hím: TAJVAN, Nantou megye, Sunmoon-tó, Lithocarpus konishii-ről gyüjtött gubacsból kinevelve (gubacs kódja: GA990309-9); 3 nőstény és 2 hím: TAJVAN (TW3, TW6), Taichung megye, Dakeng (Taichung-tól ÉK-re), Lithocarpus konishii-ről gyűjtött gubacsból kinevelve, gubacsot gyüjtötték-2008.10.21., leg. G.Melika; 2 nőstény: TAJVAN (TWT205), Taichung, Dakeng: 5-1-es túraútvonal, Lithocarpus konishii-röl gyüjtött rügygubacsból kinevelve (gubacs kódja: TWTb3), gubacsot gyüjtötték-2010.02.23., leg. Chang-Ti Tang.

Etimológia. Nevét Tajvan szigetének korábbi elnevezéséből (Formosa) származtatjuk.

Diagnosztika. Hímek és nőstények esetében a vertex és a nyakszirt finoman bőrszerü; postgenae a hypostomata irányában sima és fényes (16/b-c, 16/e-f ábrák); kizárólag a syntergite poszteriorális $1 / 5$-ben látható egy elmosódott, mikroméretü pontokból álló sáv. Két másik faj ( $L$. huisuni és L. dakengi) esetében a vertexen és a nyakszirten sokkal erősebb, benyomódó mintázat látható; postgenae a hypostomata irányában bőrszerű vagy finoman bőrszerű (18/b-c, 18/f-g, 20/b-c, 20/f-g ábrák); a syntergite poszteriorális $1 \frac{1}{3}-1 / 4$-ben egy sokkal szélesebb hálózatos sáv látható (19/g-h, 21/f-i ábrák).

A L. formosanus nőstény egyedeinek csápján az F1 hossza 1,8-szerese az F2 hosszának, az F2 valamivel rövidebb az F3 és az F11 hossza 1,9-szerese az F10 hosszának (16/g ábra). Ezzel szemben a L. huisuni esetében az F1 hossza csak 1,5-szerese az F2 hosszának, az F2 és F3, valamint az F10 és F11 egyformák (18/h ábra); a L. dakengi-nél pedig az F1 hossza 1,9-szerese az F2 hosszának, az F2 valamivel hosszabb az F3 és az F11 hossza csupán 1,5-szerese az F10 hosszának (20/h ábra). A L. formosanus hím egyedeinek csápján az F1 hossza 3,0-szorosa az F2 
hosszának (16/h ábra) míg a L. huisuni és L. dakengi esetében az F1 hossza csak 2,6-szerese az F2 hosszának (18/i, 20/i ábrák). A L. yunnani-nál megfigyelhető, hogy a nyakszirt és a postgena sima és sörték nélküli, a felszínén semmiféle mintázat nincs; a gena-n a malar space-től kiinduló és a szemek mögé is benyúló erőteljes, szubparalell striák láthatóak (22/a-c ábrák). A másik három említett faj esetében a nyakszirt és részben a postgena is bőrszerű vagy hálózatos, a genan pedig a malar space-től kiindulva csak gyenge striák láthatóak és ezek is csak az összetett szemek alsó szegélyéig futnak.

Leírás. NŐSTÉNY (20 példány adatai alapján). A fej és a középtest nagyon sötét barna; a csápok, szájszervek, a maxilláris- és ajaktapogatók sárgásak; lábak egyenletesen világosbarnák; a szárnyak erezete halvány; a utótest vörösesbarna, poszterodorzális része sötétebb.

$\mathrm{Az}$ arc alsó része, a malar space és a clypeus viszonylag sürün álló fehér sörtékkel borított; a homlok, a szemek mögötti gena, a postgena, nyakszirt és vertex csak gyengén sertézett. A fej lekerekített, frontális irányból a szélessége 1,2-szerese a magasságának; a mesosománál valamivel szélesebb, dorzális irányból a szélessége 2,0-szerese a hosszúságának. A szemek magassága 1,5-1,6-szerese a malar space hosszának. A malar sulcus hiányzik, számos sugárirányú barázda figyelhető meg a clypeus és az összetett szemek között. A clypeus nagyon kicsi, bőrszerü, enyhén benyomódott, ventrális éle egyenes, nem szegélyezett; az episztomális barázda elmosódott és a clypeus zavartalanul csatlakozik a arc alsó részének közepéhez; az anteriorális tentoriális gödröcské (anterial tentorial pits) kicsik és halványak; a clypeopleurostomális vonal elmosódott.

Az arc alsó részén a clypeus és a toruli, illetve a szemek alsó szegélye között határozott stria látható; központi kiemelkedő régiója halvány, rajta a toruli-ig érő striákkal. A homlok bőrszerü és fényes, rajta a toruli-tól induló és a középső pontszemig futó finom hosszanti striák, illetve olyan szabálytalan lefutású striák láthatóak melyek a toruli mindkét oldalán láthatóak és az oldalsó pontszemekig futnak. A transfacialális távolság (transfacial distance) 1,2-szerese a szemek magasságának; a szem belső szegélye és a antennal torulus-ok között mért távolság valamivel rövidebb, mint az antennal torulus átméröje; az antennal torulus átmérője kétszerese az antennal torulus-ok között mért távolságnak. POL hossza 1,6-szerese az OOL-nek és 1,8-szorosa a LOL-nak; OOL hossza az oldalszemek távolságának kétszerese. A vertex és a pontszemek közötti tér bőrszerü. A nyakszirt sima, bőrszerü vagy hálózatos, szinte függőlegesen fut lefele, nem kanyarodik visszafelé; occipital carina hiányzik. Frontális irányból nézve a gena a szem mögött nem szélesedik ki, felülete finoman börszerü, rajta néhány sörte található. A gena-t a postgena-tól éles barázda választja el. Postgena nagyon finoman bőrszerü, ventrális felében szinte sima és fényes. A postgenal bridge hosszú és keskeny középső sávvá redukálódott; 
postgenal sulcus-ok teljes hosszukban egyesülnek; poszteriorális tentorial pits-ek pontosan kivehetőek, a nyakszirt körüli terület jelentősen besüllyedt és sima, fényes felszínű. A csáp 11 flagellomerből áll, a pedicel hossza 2,25-szorosa a szélességének, az F1 hossza 1,8-szerese az F2 hosszának és 1,3-szerese a pedicel hosszának; F2 éppen csak egy kicsivel rövidebb az F3, az F11 hossza 1,9-szerese az F10 hosszának; placoid sensilla-k tisztán láthatóak az F5-F11 felszínén.

Laterális irányból a középtest valamivel hosszabb a magasságánál. Dorzális irányból a pronotum oldala lekerekített; felülete egyenletesen barázdált, oldalirányban néhány erős, szabálytalan lefutású stria található rajta amelyek között a felszín sima és fényes. A pronotum laterális barázdája rövid, de mindig jelen van. A propleuron bőrszerü, fényes. A tegula frontális szegélye mentén mérve a mesoscutum valamivel szélesebb mint amilyen hosszú, rajta csak igen kevés fehér sörte látható amelyek a pronotum mentén sürübben helyezkednek el; felületét keresztirányú ráncok díszítik melyek a notauli között teljesek és a notaulus-tól a mesoscutum széléig futnak A ráncok közötti terület sima és fényes, a keresztirányú ráncok között néhány rövid, hosszanti lefutású szabálytalan anasztomózis található. A notauli teljesek, elérik a pronotumot, posteriori részükön csak nagyon kismértékben szélesednek ki, sima és fényes alján néhány párhuzamos ránc fut. A mesoscutum anteriorális részén futó párhuzamos vonalak hiányoznak. A parapsidális vonalak (parapsidal line)a keresztirányú ráncok alatt láthatatlanok; elkülöníthető parascutal carina csak a tegula-k mentén található; a harántirányú ráncok között a középtest középső vonala (median mesoscutal line) láthatatlan vagy poszteriorálisan egy nagyon rövid szárú háromszöget képez. A dorsoaxillar area egységesen börszerü; a lateroaxillar area hegyesszögben csatlakozik a dorsoaxillar area-hoz ami szintén egységesen bőrszerü, fényes. A mesoscutellum majdnem olyan hosszú mint amilyen széles, egységesen durván bőrszerü, rajta erős szabálytalan ráncok találhatóak. A scutellar fovea besüllyedt, egymástól világosan elkülönülnek a köztük található nagyon keskeny median carina-nak köszönhetően. Sima és fényes aljukon erős párhuzamos hosszanti ráncok láthatóak. A mesopleuron recézett és finom, párhuzamos hosszanti striákkal tarkított. A metapleural sulcus a mesopleuront annak felső $1 / 7$-ben éri el. A propodeum fényes, szőrtelen, a central propodeal area-tól laterális irányban ritkásan álló rövid fehér sertékkel; a propodeum oldalsó barázdája (lateral propodeal carina) jól kivehető, teljes hosszán azonos szélességü; a propodeal area középső része sima és fényes, striák nélküli. A metascutellum nagyon keskeny, sokkal rövidebb mint a ventrális benyomódott terület; a metanotális vályú (metanotal trough) sima és fényes, rajta fehér sörték találhatóak; a propodeum légzőnyílásai (propodeal spiracle) keresztirányban tojásdadok, anterior határuk mentén erősen kiemelkedő borda található. A nucha sötétbarna, rajta hosszanti párhuzamos barázdaek láthatóak. 
Az elülső szárny a testnél hosszabb, átlátszó, a szegélyén hosszú és sürün álló sörtékkel, radiális sejtjének hossza 2,7-szerese a szélességének; R1 sejtje megközelíti a szárny szegélyét; az areolet nem kifejezetten látható; Rs és M erek nagyon halványak. A lábtőkarmok minden esetben egyszerüek, elkülönült bazális lebeny nélküliek.

a)
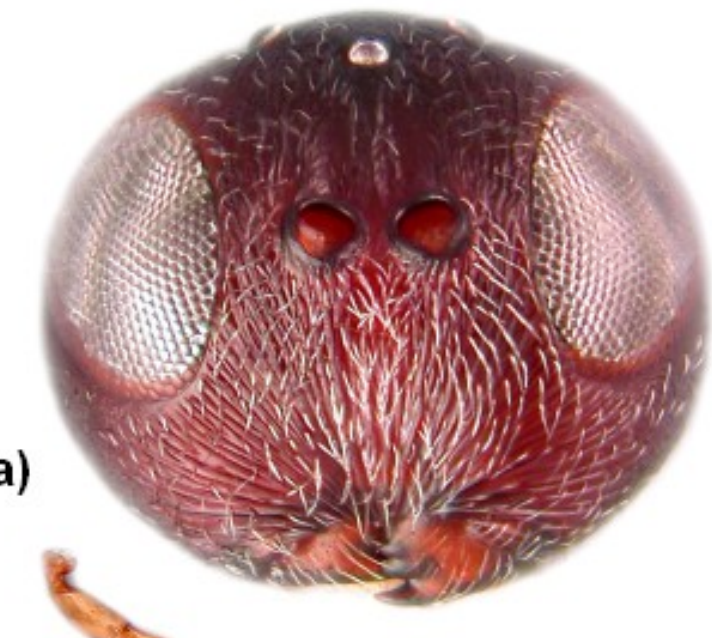

g)

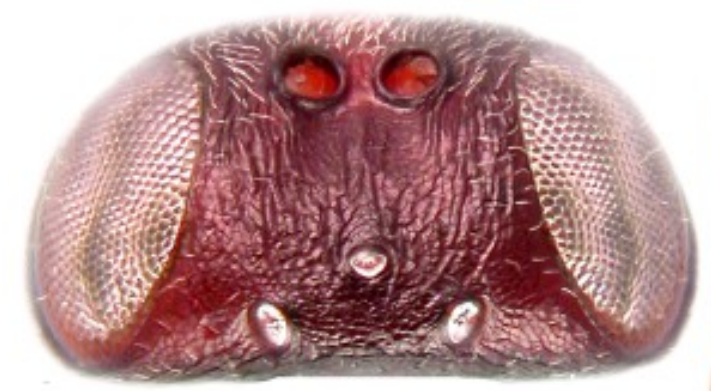

b)
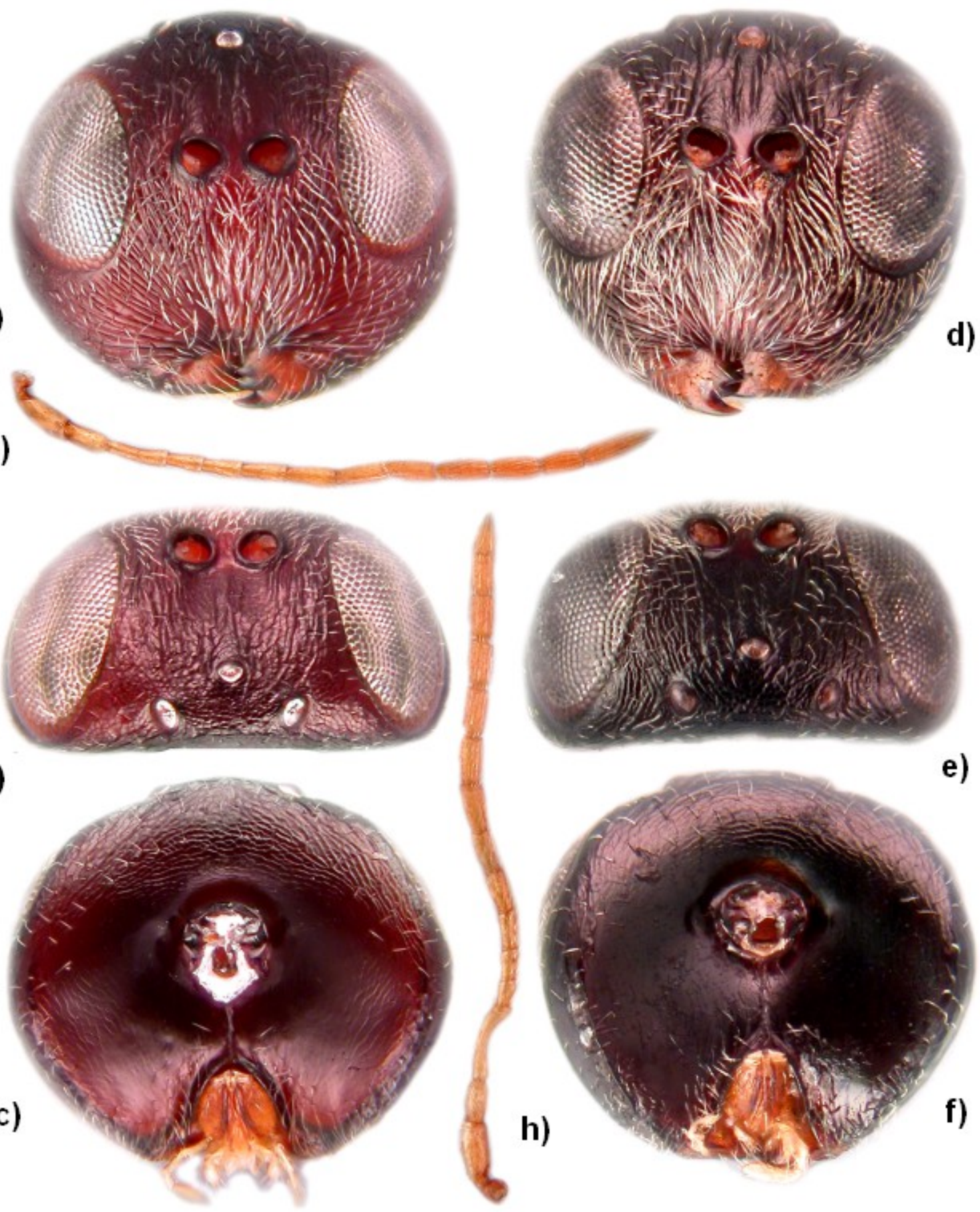

d)

e)

16. ábra: Lithosaphonecrus formosanus: a)-c) nőstény példány feje: a) frontális irányból, b) dorzális irányból, c) poszterior irányból; d)-f) hím példány feje: d) frontális irányból, e) dorzális irányból, f) poszterior irányból; g)-h) csápok: g) nőstény, h) hím. 


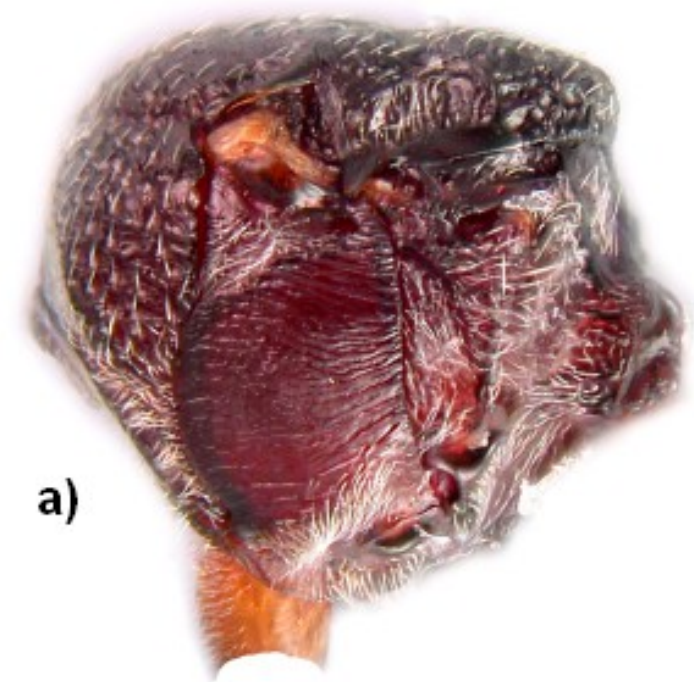

b)
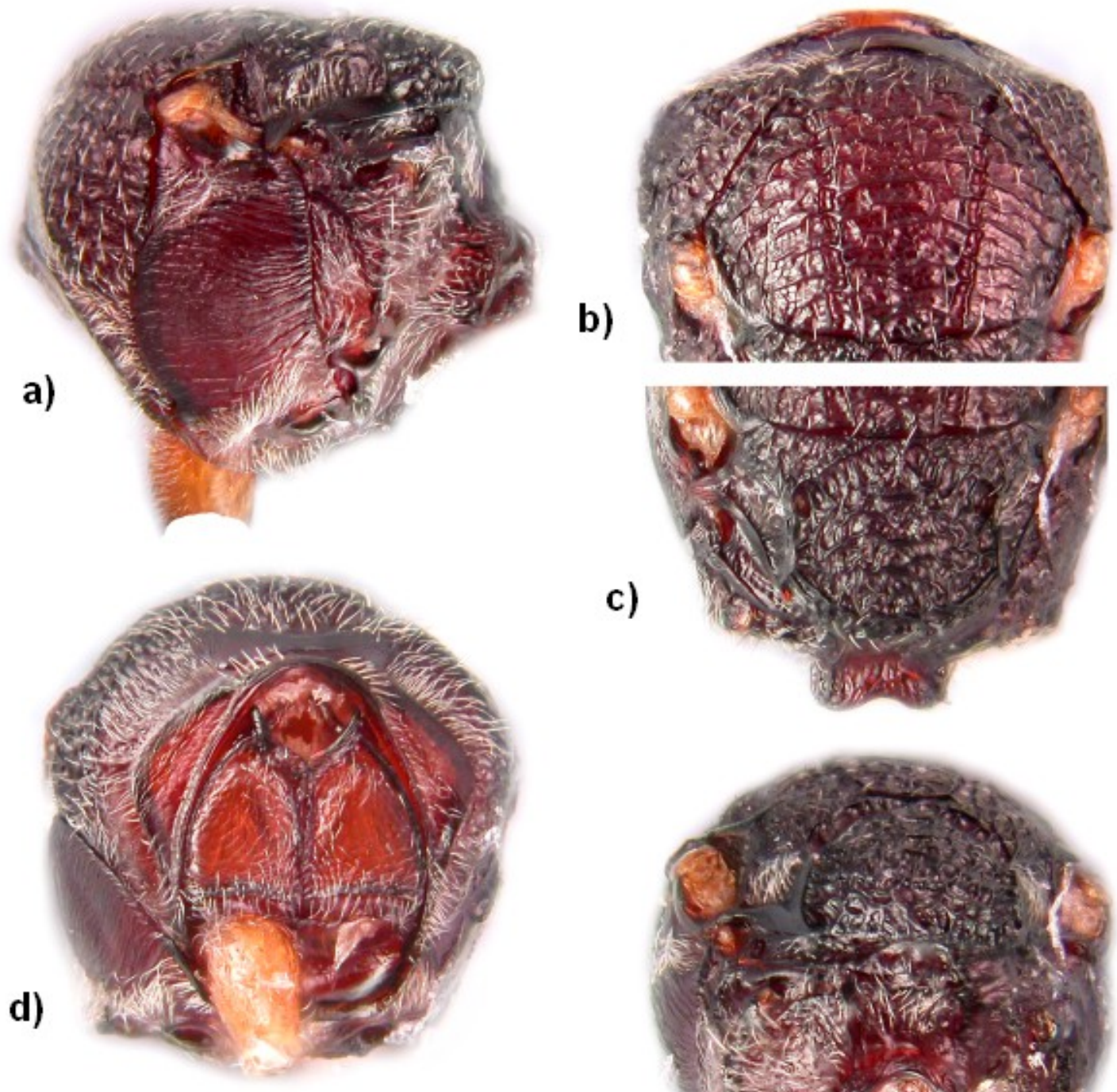

c)
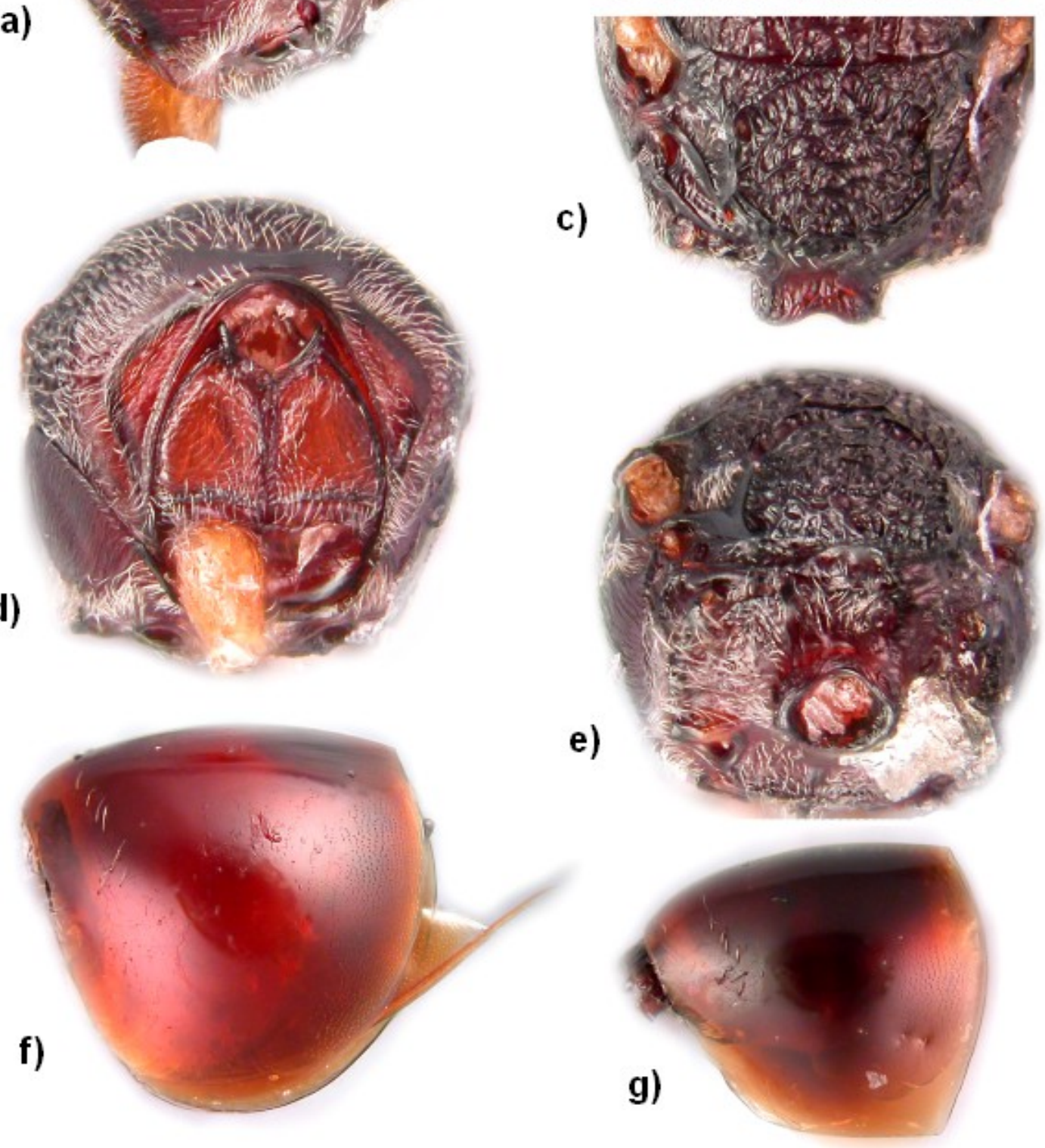

17. ábra: Lithosaphonecrus formosanus: a)-f) nőstény példány: a) mesosoma laterális irányból, b) mesoscutum dorzális irányból, c) mesoscutellum dorzális irányból, d) pronotum és propleuron frontális irányból, e) metascutellum és propodeum poszterodorzális irányból, f) metasoma laterális irányból; g) hím metasoma laterális irányból. 
A utótest hossza közel megegyezik a fej és középtest együttes hosszával és laterális irányból tekintve valamivel hosszabb mint amilyen magas. A syntergite sima, fényes és csillogó, anterolaterális részén néhány fehér sertével; poszterodorzális része erősen kimetszett. Felszínének poszteriori 1/5-én mikroméretü pontokból álló sáv található, mely eléri a ventrális szegélyt. Az ezt követő tergiteken és a hypopygium-on mikropontozottság látható; a hypopygium ventrális barázdájának kiemelkedő része nagyon rövid és keskeny, ventrális részén néhány rövid fehér sörtével. A test hossza 1,6-1,9 mm.

HÍM (20 példány adatai alapján). A nőstényhez hasonló megjelenésű de a teste - különösképpem az utótest területén - világosabb; a csápok és a lábak - beleértve a csípöket is sárgák vagy sárgásbarnák; a csáp 13 flagellomerből áll, az F1 ívelt, apikális részén meggörbült és kiszélesedett, hossza 3,0-szorosa az F2-nek ; az F1 hossza 1,3-szerese az F2 és F3 együttes hosszának; az F4 hossza 1,3-szerese az F3 hosszának; az F4-F13 mérete közel azonos; a placoid sensilla-kat sztereomikroszkóppal nehezen lehet észrevenni. A test hossza 1,4-1,7 mm.

Életmód. A Lithosaphonecrus formosanus kifejlett példányait a rügygubacsok háromféle, a barka-és szárgubacsok egy-egy morfotípusából nevelték ki. A gubacsok különböző Lithocarpus fajokról származtak. Az első (TWb2)(18/a ábra) egy a L. konishii és L. glabra fajokon egyaránt előforduló, szabálytalanul duzzadt alakú, terminális vagy laterális helyzetű rügygubacs volt amely akár 8-10 mm hosszúra és 4 mm-es átmérőjüre is megnőhet. A második ( $\mathrm{TWb} 7=\mathrm{TWTb} 2)$ (18/b-c ábrák) a L. konishii, L. hancei és L. glabra fajokon található szabálytalanul kerek felszínü lapos, kerek rügygubacs melynek felső része lapított, a tetején egy kis bemélyedés is látható, akár $15 \mathrm{~mm}$ átmérőjü és $10 \mathrm{~mm}$ hosszúságú is lehet. Frissen zöld színű amely érés közben barnára változik. A harmadik (TWb3) (18/d ábra) a L. konishii fajról gyüjtött megduzzadt, kórosan felfúvódott rügygubacs - melyen még a pikkelyek is jelen voltak - amely a friss hajtások terminális végén klaszterekben helyezkedett el. Az egyetlen, L. glabra-ról gyüjtött barkagubacs (TWc2) (18/e ábra) nagyjából gömb alakú, 4-5 mm átmérőjű volt. Halványbarna felületén tompa tüskék voltak melyek között sürün álló rövid pihék borították a gubacsot. A TWs5 (19.ábra) volt az egyetlen begyüjthető szárgubacs amelyből nagy számbansikerült inquilineket kinevelni. A L. konishii vesszőiről begyüjtött tengeri sün-szerű gubacsok átmérője 3$4 \mathrm{~mm}$, a tüskék hossza maximum $5 \mathrm{~mm}$. A fiatalabb gubacsok zöldes árnyalatúak, a tüskék lilásak. Ebből a típusból néhány gubacs sokkal nagyobb, akár $12 \mathrm{~mm}$-es átmérőjű is volt. Ezek felszínén rövidebb tüskéket míg belsejükben több kamrát találtunk (19/c ábra) ami valószínüleg az inquilinek gubacson belüli fejlödésének volt a következménye. Az összes említett gubacstípust októberben gyüjtötték, a kifejlett inquilinek labor körülmények között ugyanabban 
az évben október-novemberben megjelentek.

EIterjedés. Jelenleg kizárólag Tajvan Nantou és Taichung megyéiből ismert.
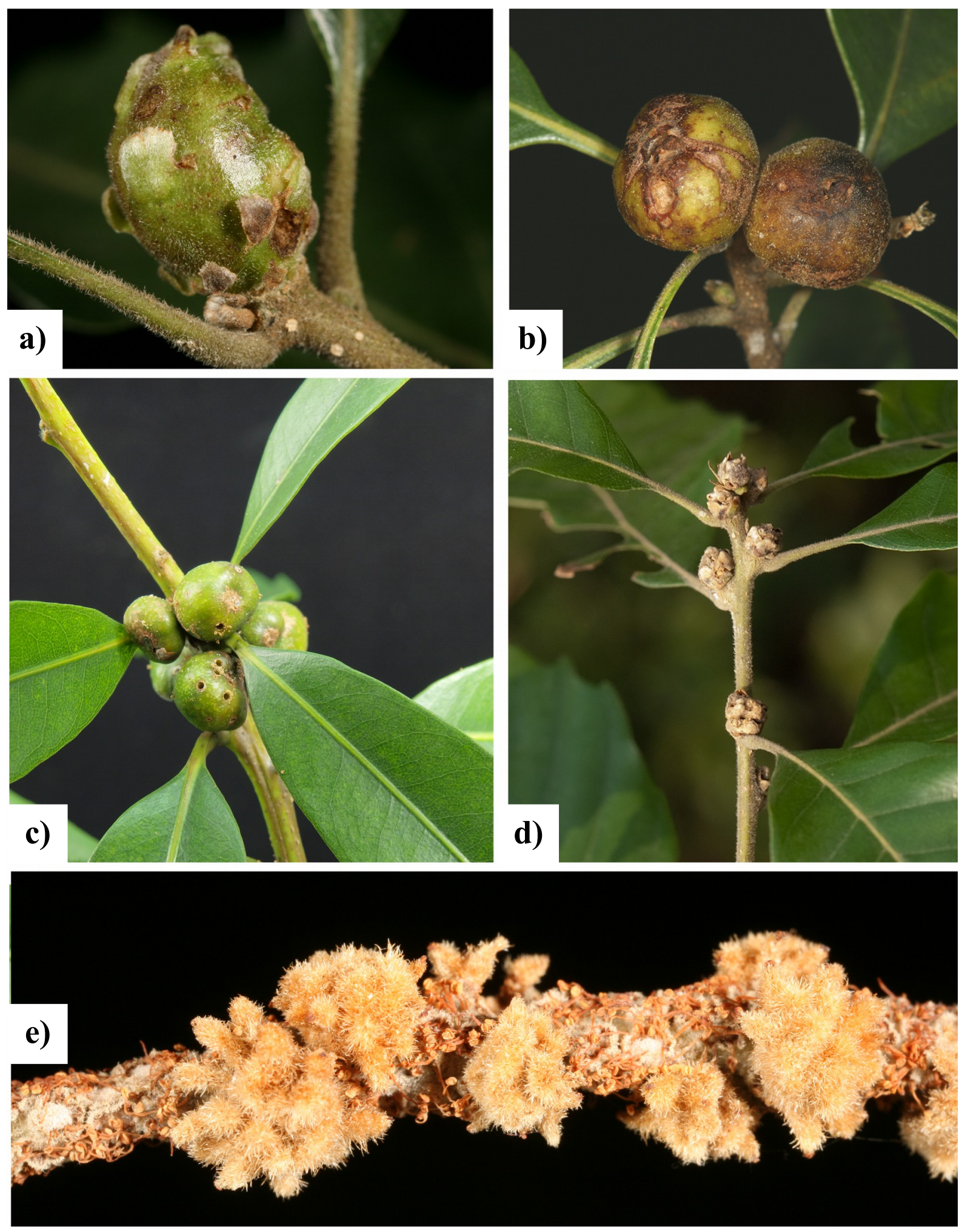

18. ábra: A Lithocarpus fajokról begyüjtött gubacsok, amelyekből a Lithosaphonecrus formosanus példányait kinevelték: a) ismeretlen rügygubacs $(\mathrm{TWb} 2), \mathrm{b})$ ismeretlen rügygubacs $(\mathrm{TWb} 7=\mathrm{TWTb} 2), \mathrm{c})$ ismeretlen rügygubacs $(\mathrm{TWb} 7=\mathrm{TWTb} 2), \mathrm{d})$ ismeretlen rügygubacs $(\mathrm{TWb} 3)$, e) ismeretlen barkagubacs (TWc2) (Forrás: Csóka Gy. és C.-T. Tang) 

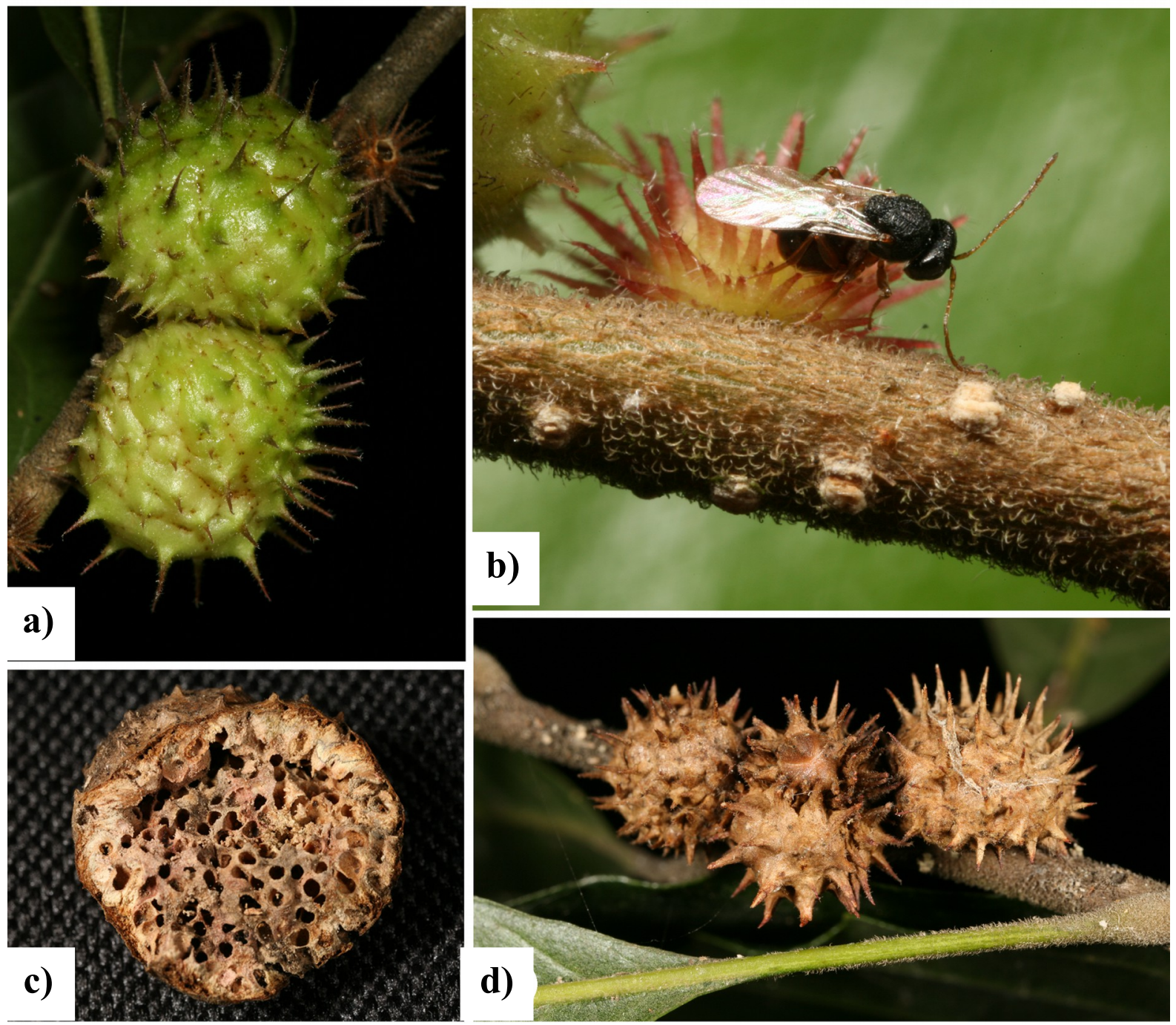

c)

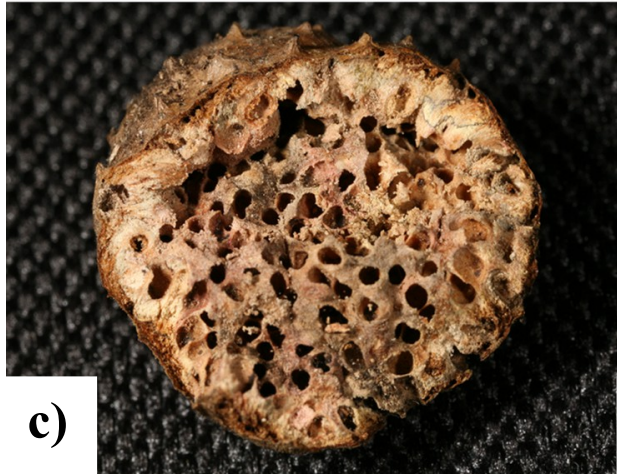

19. ábra: A Lithocarpus fajokról begyüjtött „tengeri sün”-szerü szárgubacs (TWs5), amelyből a Lithosaphonecrus formosanus példányait is kinevelték: a) fiatal növekvő gubacs; b) nöstény Lithosaphonecrus pédány tojásrakás közben sp.; c) a gubacs keresztmetszetén jól látszanak Lithosaphonecrus faj lárváinak kamrái; d) érett gubacsok. (Forrás: Csóka Gy. és C.-T. Tang)

\section{Lithosaphonecrus huisuni Tang, Bozsó \& Melika}

20-21. ábrák

Típus példány. HOLOTÍPUS nőstény: TAJVAN (TWT271; TWT273; TWT274; TWT277; TWT278), Nantou megye, Huisun Forest Station, Renai Township, Lithocarpus glabra-ról gyüjtött ismeretlen rügygubacsból kinevelve (gubacs kódja: $\mathrm{TWb7}=\mathrm{TWTb} 2$ ), gubacsot gyüjtötték-2009.09.17., leg. Chang-Ti Tang.

14 nőstény és 7 hím paratípus a holotípussal megegyező címkével lett ellátva. A nőstény holotípus. 4 nőstény és 2 hím paratípus az NMNS, 4 nőstény és 2 hím paratípus a PHMB, 4 nőstény és 2 hím paratípus az NCHU, 2 nőstény és 1 hím paratípus az USNM gyüjteményében lett elhelyezve. 
Egyéb példányok. 14 nőstény és12 hím: TAJJVAN (TWT273; TWT274; TWT277), Nantou megye, Huisun Forest Station, Renai Township, Lithocarpus glabra-ról gyüjtött ismeretlen rügygubacsból kinevelve (gubacs kódja: TWb7 = TWTb2), gubacsot gyüjtötték-2009.09.17., leg. Chang-Ti Tang.

Etimológia. A faj nevét arról a Huisun Forest Station-ről kapta ahol példányait első ízben begyüjtötték.

Diagnosztika. A kiszámított genetikai távolságok alapján a L. huisuni legközelebbi rokon fajának a L. yunnani bizonyult (Bozsó és mtsi 2013). A L. huisuni esetében a nyakszirt bőrszerütől hálózatos lehet; a postgena dorzális fele bőrszerü és csak a poszterior fele sima, szőrtelen; a gena néhány szubparallel, megszakadó striát visel melyek a malar space-től az összetett szemek ventrális szegélyéig futnak (20/a-d, 20/e-g ábrák); a frontális helyzetü párhuzamos és a középső mesoscutális vonalak (median mesoscutal lines) hiányoznak; a mesopleuron anteroventrális negyedében határozottan hálózatos, a mesopleuron többi részén hosszanti lefutású finom striák láthatóak (21/a-b ábrák). Ezzel ellentétben a L. yunnani-nál a nyakszirt és a postgena egyenletesen sima, szőrtelen; a gena erős, megszakadó szubparallel striákat visel melyek a malar space-től indulnak és az összetett szemek mögött végződnek (24/a-d ábrák); a frontális helyzetü párhuzamos vonalak elkülöníthetőek, a közéspő mesoscutális vonal (median mesoscutal line) a mesoscutum félhosszáig ér; a mesopleuron felületének 3/4-e egyenletesen recézett, párhuzamos striák csak a dorzoposzteriorális részén láthatóak (25/a-d ábrák). A L. huisuni esetében a syntergite poszteriori részén a recézett sáv szélessége megegyezik a utótest hosszának negyedével (21/g ábra) miközben a L. formosanus-nál a mikropontozott sáv szélessége maximum a utótest hosszának $1 / 5$-e (17/f ábra).

Leírás. NÖSTÉNY (10 példány adatai alapján). A fej frontális és dorzális irányból sötét vörösesbarna, poszteriorális részén szinte fekete; a csápok az utolsó fekete flagellomer kivételével egyenletesen vörösesbarnák; szájszervek, a maxilláris- és ajaktapogatók sárgásak; lábak egyenletesen vörösesbarnák; a szárnyakon pontosan kivehetőek a barna színü $\mathrm{R}+\mathrm{Sc}$, $\mathrm{R} 1+\mathrm{Sc}, \mathrm{M}, \mathrm{R} 1,2 \mathrm{r}$ és Rs erek, a többi ér halvány és nehezen követhető; a középtest dorzális része fekete, laterális része sötétbarna; a utótest sötét vörösesbarna, a hypopigium ventrális barázdája sokkal világosabb.

Az arc alsó része, a malar space és a clypeus viszonylag sürün álló fehér sörtékkel borított; a homlok, a szemek mögötti gena, a postgena, nyakszirt és vertex csak gyengén sertézett. A fej trapezoid, anterior irányból a szélessége 1,2-szerese a magasságának; a mesosománál valamivel szélesebb, dorzális irányból a szélessége 2,3-szerese a hosszúságának. A szemek magassága 1,5-szerese a malar space hosszának. A malar space malar sulcus nélküli, 
számos finom sugárirányú barázda figyelhető meg a clypeus és az összetett szemek között. A clypeus nagyon kicsi, bőrszerü, enyhén benyomódott, ventrális éle egyenes, nem szegélyezett; az episztomális barázda (epistomal sulcus): elmosódott és a clypeus zavartalanul csatlakozik a arc alsó részének közepéhez; az anteriorális tentorial pits-ek kicsik és halványak; a clypeopleurostomális vonal (clypeo-pleurostomal line)elmosódott.

$\mathrm{Az}$ arc alsó részén a clypeus és a toruli, illetve a szemek alsó szegélye között nagyon finom striák láthatóak; központi kiemelkedő régiója halvány, rajta a toruli-ig érő striákkal. A homlok bőrszerü és fényes, rajta a toruli-tól induló és a középső pontszemig futó finom hosszanti striák, illetve olyan szabálytalan lefutású striák láthatóak melyek a toruli mindkét oldalán láthatóak és az oldalsó pontszemekig futnak. A transfacial distance megegyezik az összetett szem magasságával; a szem belső szegélye és a antennal torulus között mért távolság valamivel hosszabb, mint a torulus átméröje; a torulus átméröje 2,1-szerese a torulus-ok között mért távolságnak. POL hossza 1,8-szerese az OOL-nek és 2,1-szerese a LOL-nak; OOL hossza az oldalszemek távolságának 2,4-szerese. A vertex és a pontszemek közötti tér bőrszerü.A nyakszirt recézett és fényes, szinte függőlegesen fut lefele, nem kanyarodik visszafelé; occipital carina hiányzik. Frontális irányból nézve a gena a szem mögött nem szélesedik ki, felülete finoman bőrszerü, rajta néhány sörte található; finom szubparallel szaggatott striák futnak a malar space és a gena-t a postgena-tól élesen elválasztó barázda között. Postgena a hypostomal carina irányába eső ventrális $1 / 3$-án szőrtelen és bőrszerü, dorzális $2 / 3$-ban hálózatos vagy bőrszerü. A postgenális híd hosszú, keskeny középső sávvá redukálódott; postgenal sulcus-ok teljes hosszukban egyesültek; poszteriorális tentorial pits-ek pontosan kivehetőek, a nyakszirt körüli terület jelentősen besüllyedt és sima, fényes felszínü. A csáp 11 flagellomerből áll, a pedicel hossza 1,9-szerese a szélességének, az F1 hossza 1,5-szerese az F2 hosszának és 1,5-szerese a pedicel hosszának; F2 és F3 hossza megegyezik, az F11 hossza 1,9-szerese az F10 hosszának; placoid sensilla-k tisztán láthatóak az F5-F11 felszínén.

Laterális irányból a középtest hosszabb a magasságánál. Dorzális irányból a pronotum oldala lekerekített; felülete durván barázdált, oldalirányban néhány erős, szabálytalan lefutású stria található rajta amelyek között a felszín sima és fényes. A pronotum laterális barázdája rövid, de mindig jelen van. A propleuron sima és fényes. A tegula anterior szegélye mentén mérve a mesoscutum szélesebb mint amilyen hosszú, rajta csak igen kevés fehér sörte látható amelyek a pronotum mentén sürübben helyezkednek el; felületét keresztirányú ráncok díszítik melyek a notauli között teljesek és a notaulus-tól a mesoscutum széléig futnak A ráncok közötti terület sima és fényes, a keresztirányú ráncok között néhány rövid, hosszanti lefutású szabálytalan anasztomózis található. A notauli teljesek, elérik a pronotumot, posteriori részükön csak nagyon 
kismértékben szélesednek ki, sima és fényes alján néhány párhuzamos ránc fut. A mesoscutum frontális részén futó párhuzamos vonalak hiányoznak. A parapsidális vonalak keskenyek, elkülöníthetőek; elkülöníthető parascutális barázda csak a tegula mentén található; a haránt irányú ráncok között a mesoscutum középső vonala láthatatlan vagy poszteriorálisan egy nagyon rövid szárú háromszöget képez. A dorsoaxillar area durván börszerü és fényes; a lateroaxillar area hegyesszögben csatlakozik a dorsoaxillar area-hoz ami szintén durván börszerü, fényes.

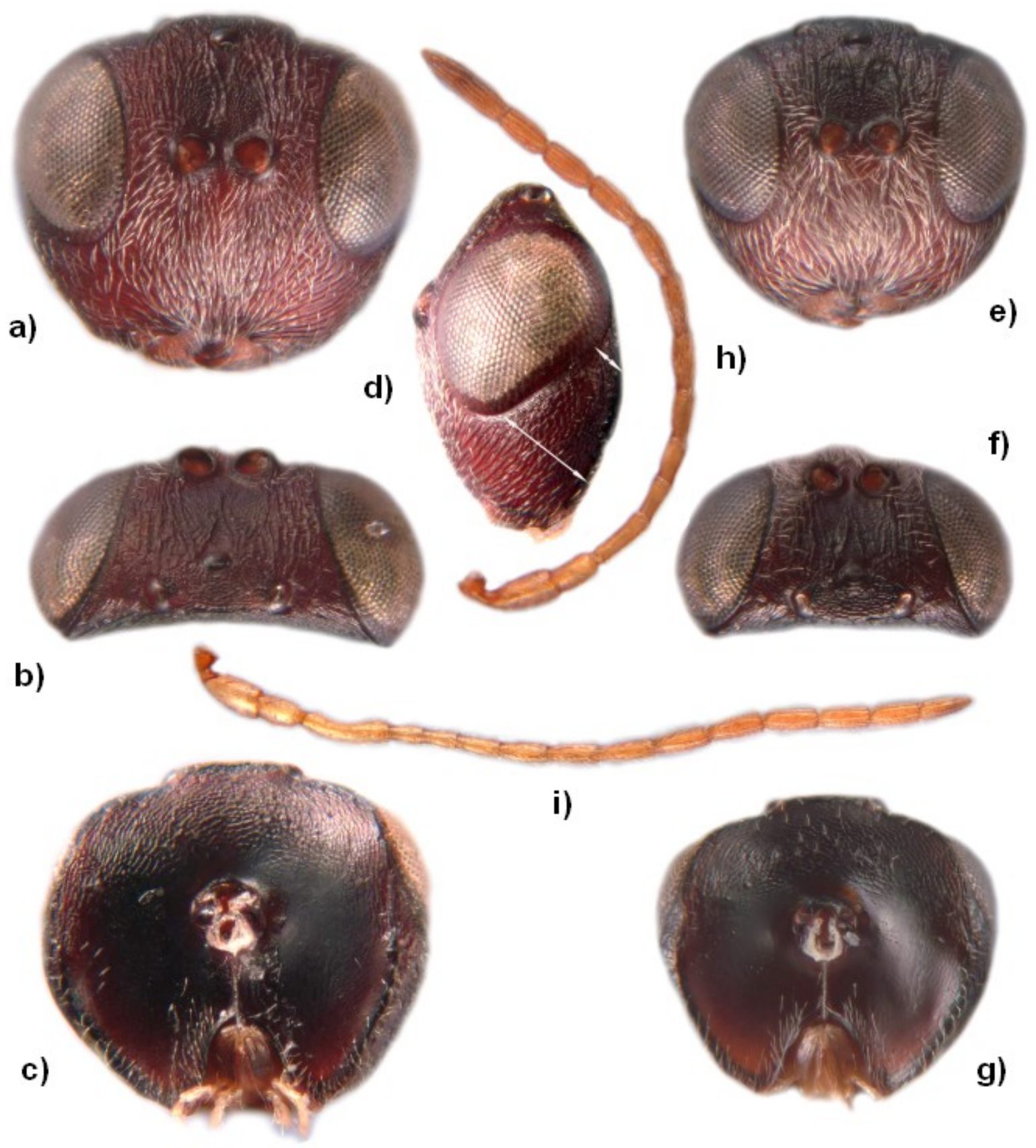

20. ábra: Lithosaphonecrus huisuni: a)-d) nőstény példány feje: a) frontális irányból, b) dorzális irányból, c) poszterior irányból; d) laterális irányból; e)-g) hím példány feje: e) frontális irányból, f) dorzális irányból, g) poszterior irányból; h)-i) csápok: h) nőstény, i) hím. 


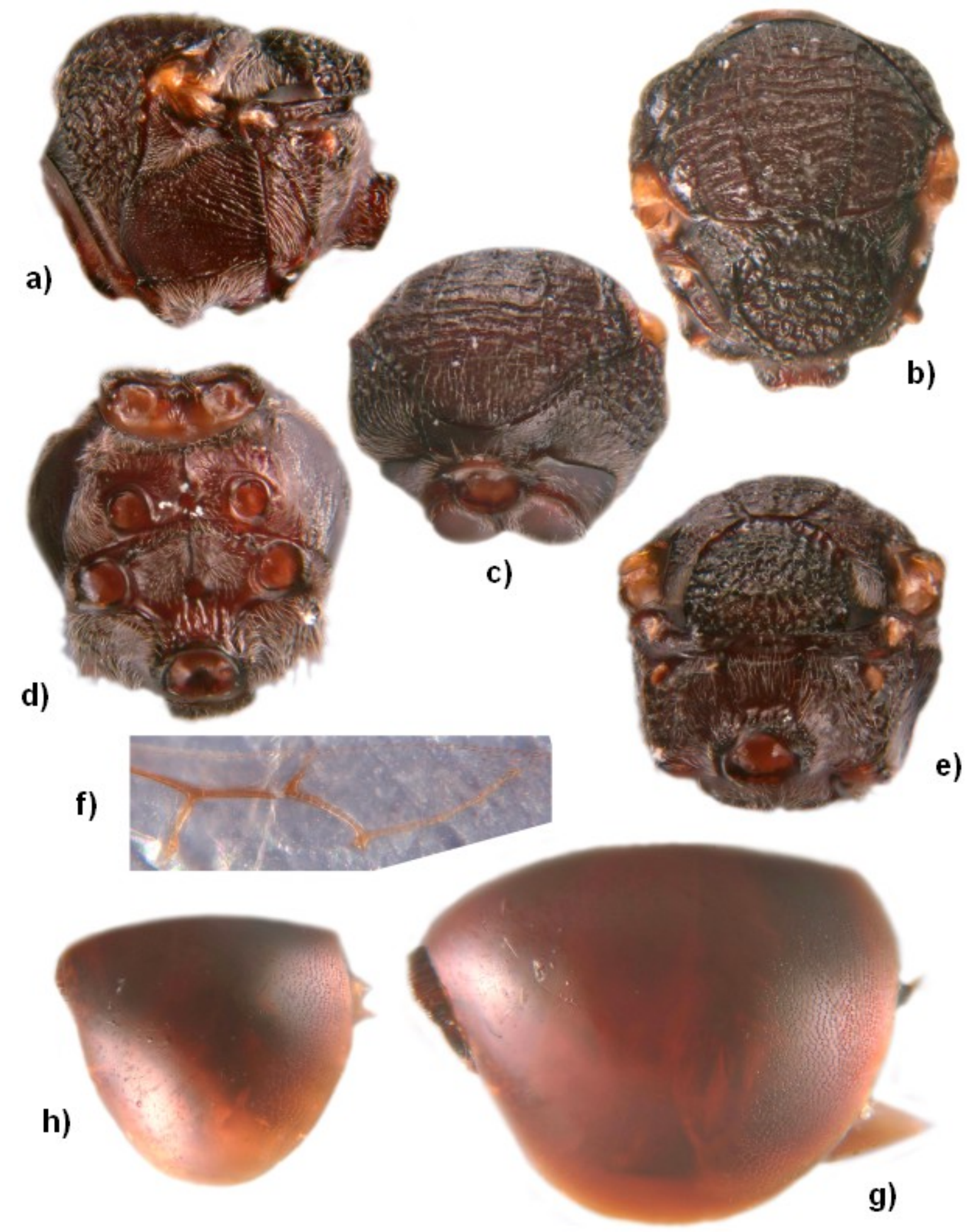

21. ábra: Lithosaphonecrus huisuni: a)-g) nőstény példány: a) mesosoma laterális irányból, b) mesosoma dorzális irányból, c) mesosoma frontális irányból, d) mesosoma ventrális irányból, e) metascutellum és propodeum poszterodorzális irányból, f) elülső szárny radiális sejtje, g) metasoma laterális irányból; h) hím metasoma laterális irányból.

A mesoscutellum majdnem olyan hosszú mint amilyen széles, durván bőrszerü, rajta erős szabálytalan ráncok találhatóak. A scutellar fovea besüllyedt, egymástól világosan elkülönülnek 
a köztük található nagyon keskeny median carina-nak köszönhetően. Sima és fényes aljukon erős párhuzamos hosszanti ráncok láthatóak. A mesopleuron ventrális felében recézett, dorzális felében finom, párhuzamos hosszanti striákkal tarkított. A metapleurális barázda a mesopleuront annak felső $1 / 7$-ben éri el. A propodeum sima, szőrtelen, a central propodeal area-tól laterális irányban ritkásan álló rövid fehér sörtékkel; az propodeum oldalsó barázdája jól kivehető, teljes hosszán azonos szélességü; a propodeal area középső része sima és fényes, striák nélküli. A metascutellum nagyon keskeny, sokkal rövidebb mint a ventrális benyomódott terület; a metanotális vályú sima és fényes, rajta fehér sörték találhatóak; a propodeum légzőnyílásai keresztirányban tojásdadok, anterior határuk mentén erősen kiemelkedő borda található. A nucha sötétbarna, rajta hosszanti párhuzamos barázdák láthatóak.

Az elülső szárny a testnél hosszabb, átlátszó, a szegélyén hosszú és sűrün álló sörtékkel, radiális sejtjének hossza 2,7-szerese a szélességének; R1 sejtje megközelíti a szárny szegélyét; az areolet nem kifejezetten látható; Rs és M nagyon halványan látszanak. A lábtőkarmok minden esetben egyszerüek, elkülönült bazális lebeny nélküliek. A utótest hossza 1,3-szerese a magasságának és nagyobb a fej és középtest együttes hosszánál. A syntergite sima, fényes és csillogó, anterolaterális részén néhány fehér sörtével; poszterodorzális része erősen kimetszett. Felszínének poszteriori ${ }^{1} / 4$-én recézettfelületủ sáv található, mely eléri a ventrális szegélyt. Az ezt követő tergiteken és a hypopygium-on mikroméretü recézettség látható; a hypopygium ventrális barázdaének kiemelkedő része nagyon rövid és keskeny, ventrális részén néhány rövid fehér sörtével. A test hossza 1,7-1,9 mm.

HÍM (5 példány adatai alapján). A nőstényhez hasonló megjelenésű, a csápok és a lábak beleértve a csípőket is - sárgásbarnák; a csáp 13 flagellomerből áll, az F1 ívelt és apikális részén kiszélesedett, hossza 2,6-szerese az F2-nek; az F1 hossza 1,3-szerese az F2 és F3 együttes hosszának; az F4 hossza 1,25-szorosa az F3 hosszának; az F4-F11 mérete közel azonos; a placoid sensilla-kat sztereomikroszkóppal nehezen lehet észrevenni. A test hossza 1,5-1,8 mm.

Életmód. A Lithosaphonecrus huisuni kifejlett példányait csak egyetlen gubacsból nevelték ki ( $\mathrm{TWb} 7=\mathrm{TWTb} 2)$, melynek leírása megtalálható a L. formosanus faj jellemzésénél. A gubacsokat október közepén gyüjtötték L. glabra-ról, a kifejlett inquilinek labor körülmények között ugyanabban az évben október végén-november elején megjelentek.

Elterjedés. Jelenleg kizárólag Tajvan Nantou megyéjéből ismert. 


\section{Lithosaphonecrus dakengi Tang \& Pujade-Villar}

22-23. ábrák

Típus példány. HOLOTÍPUS nőstény: TAJVAN (TWT144; TWT145), Taichung megye, Dakeng:5-1-es túraútvonal, Taichung, Lithocarpus hancei-ről gyűjtött ismeretlen rügygubacsból kinevelve (gubacs kódja: TWb7 = TWTb2), gubacsot gyüjtötték-2010.04.16., leg. Chang-Ti Tang. 12 nőstény és 6 hím paratípust a holotípussal azonos cimkével láttak el. A nőstény holotípu, 2 nőstény és 1 hím paratípust az NMNS, 4 nőstény és 2 hím paratípust a PHMB, 4 nőstény és 2 hím paratípust az NCHU, 2 nőstény és 1 hím paratípust az USNM gyüjteményeiben helyeztek el.

Etimológia. A faj nevét arról a helyről (Dakeng) kapta ahol példányait első ízben begyűjtötték.

Diagnosztika. A faj mindkét nemre jellemző, hogy a hypostoma barázdája (hypostomal carina) mentén a postgena felületén egy széles fehéres, selymes terület van jelen (22/c, 22/g ábrák) miközben a L. formosanus és L. huisuni esetében a hypostoma barázdája mentén csak elszórtan álló fehér sörték láthatóak (17/c, 17/f, 21/c, 21/g ábrák). A L. dakengi esetében a fej és a utótest általában nagyon sötétbarna vagy fekete miközben a L. formosanus és L. huisuni fajoknál a fej barna vagy esetleg sötétebb barna árnyalatú. A L. dakengi nőstényének csápján a L. formosanus fajnál láthatóhoz hasonlóan az F1 hossza 1,9-szerese az F2 hosszának, F2 valamivel hosszabb az F3-nál (22/h ábra). A L. formosanus esetében az F2 valamivel rövidebb mint az F3, a L. huisuninál pedig az F1 hossza csak 1,5-szöröse az F2 hosszának, F2 ésF3 nagysága megegyezik (20/h ábra). A L. dakengi postgena-ja a ventrális felében finoman börszerü (22/c, 22/g ábrák), csakúgy mint ahogyan a L. huisuni esetében látható (20/c, 20/g ábrák). A L. formosanus-nál ezzel szemben a postgena-k ventrális felükön simák vagy finoman bőrszerüek (16/c, 16/f ábrák).

Leírás. NÖSTÉNY (10 példány adatai alapján). A fej frontális és dorzális irányból sötét vörösesbarna vagy fekete, poszteriorális részén szinte fekete; a csápok az utolsó flagellomer fekete csúcsának kivételével egyenletesen vörösesbarnák; szájszervek, a maxilláris- és ajaktapogatók sárgásak; lábak egyenletesen vörösesbarnák; a szárnyakon pontosan kivehetőek a barna színü R+Sc, R1+Sc, M, R1, 2r és Rs erek, a többi ér halvány és nehezen követhető; a középtest fekete; a utótest sötét vörösesbarna vagy fekete, a hypopigium ventrális barázdája sokkal világosabb.

$\mathrm{Az}$ arc alsó része, a malar space és a clypeus viszonylag sürün álló fehér sörtékkel borított; a homlok, a szemek mögötti gena, a postgena, nyakszirt és vertex csak gyengén sertézett. A fej kerekded, frontális irányból a szélessége 1,2-szerese a magasságának; a mesosománál valamivel szélesebb, dorzális irányból a szélessége 1,9-2,1-szerese a hosszúságának. A szemek magassága 1,3-szerese a malar space hosszának. A malar space malar sulcus nélküli, számos finom sugárirányú barázda figyelhető meg a clypeus és az összetett szemek között. A clypeus 
nagyon kicsi, bőrszerü, enyhén benyomódott, ventrális éle egyenes, nem szegélyezett; az episztomális barázda elmosódott és a clypeus zavartalanul csatlakozik a arc alsó részének közepéhez; az anteriorális tentorial pits-ek kicsik és halványak; a clypeo-pleurostomális vonal elmosódott. Az arc alsó részén a clypeus és a toruli, illetve a szemek alsó szegélye között nagyon finom striák láthatóak; központi kiemelkedő régiója halvány, rajta a toruli-ig érő striákkal. A homlok bőrszerü és fényes, rajta a toruli-tól induló és a középső pontszemig futó finom hosszanti striák, illetve olyan szabálytalan lefutású striák láthatóak melyek a toruli mindkét oldalán láthatóak és az oldalsó pontszemekig futnak. A transfaciális távolság közel azonos a szemek magasságával; a szem belső szegélye és a antennal torulus között mért távolság valamivel hosszabb, mint a torulus átméröje; a torulus átméröje kétszerese a torulus-ok között mért távolságnak. POL hossza 1,4-szerese az OOL-nek és 2,3-szerese a LOL-nak; OOL hossza az oldalszemek távolságának 2,2-szerese. A vertex és a pontszemek közötti tér bőrszerü. A nyakszirt recézett és fényes, szinte függőlegesen fut lefele, nem kanyarodik visszafelé; occipital carina hiányzik. Frontális irányból nézve a gena a szem mögött nem szélesedik ki, felülete finoman bőrszerü, rajta néhány sörte található; finom szubparallel szaggatott striák futnak a malar space és a gena-t a postgena-tól élesen elválasztó barázda között. Postgena a hypostomal carina irányába eső ventrális ${ }^{1} / 3$-án szőrtelen és bőrszerü. A postgenális híd hosszú, keskeny középső sávvá redukálódott; postgenal sulcus-ok teljes hosszukban egyesültek; poszteriorális tentorial pits-ek pontosan kivehetőek, a nyakszirt körüli terület jelentősen besüllyedt és sima, fényes felszínü. A csáp 11 flagellomerből áll, a pedicel hossza 1,6-szerese a szélességének, az F1 hossza 1,9-szerese az F2 hosszának és 1,5-szerese a pedicel hosszának; F2 csak egy kicsivel hosszabb az F3-nál, az F11 hossza 1,5-szerese az F10 hosszának; placoid sensilla-k tisztán láthatóak az F5F11-en.

Laterális irányból a középtest valamivel hosszabb a magasságánál. Dorzális irányból a pronotum oldala lekerekített; felülete durván barázdált, oldalirányban néhány erős, szabálytalan lefutású stria található rajta amelyek között a felszín sima és fényes. Az pronotum laterális barázdája rövid, de mindig jelen van. A propleuron bőrszerü és fényes. A tegula anterior szegélye mentén mérve a mesoscutum szélesebb mint amilyen hosszú, rajta csak igen kevés fehér sörte látható amelyek a pronotum mentén sürübben helyezkednek el; felületét keresztirányú ráncok díszítik melyek a notauli között teljesek és a notaulus-tól a mesoscutum széléig futnak A ráncok közötti terület sima és fényes, a keresztirányú ráncok között néhány rövid, hosszanti lefutású szabálytalan anasztomózis található. A notauli teljesek, elérik a pronotumot, posteriori részükön csak nagyon kismértékben szélesednek ki, sima és fényes alján néhány párhuzamos ránc fut. A mesoscutum anteriorális részén futó párhuzamos vonalak hiányoznak. A parapsidális vonalak 
láthatatlanok a harántirányú ráncok alatt; elkülöníthető parascutal carina csak a tegula mentén található; a haránt irányú ráncok között középső mesoscutális vonal láthatatlan vagy poszteriorálisan egy nagyon rövid szárú háromszöget képez. A dorsoaxillar area börszerü és fényes; a lateroaxillar area hegyesszögben csatlakozik a dorsoaxillar area-hoz ami szintén börszerü, rajta számos fehér sörte található.

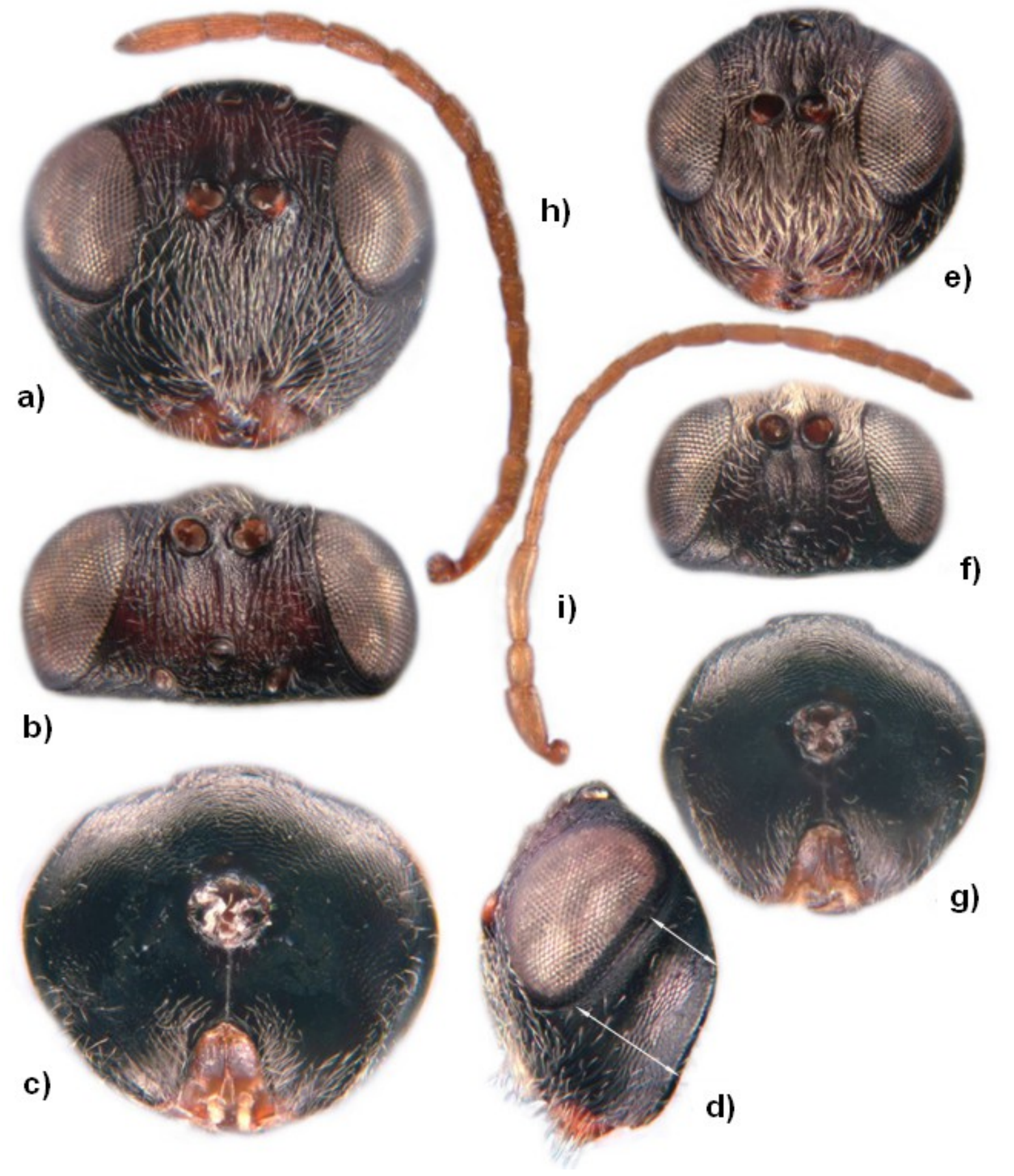

22. ábra: Lithosaphonecrus dakengi: a)-d) nőstény példány feje: a) frontális irányból, b) dorzális irányból, c) poszterior irányból; d) laterális irányból; e)-g) hím példány feje: e) frontális irányból, f) dorzális irányból, g) poszterior irányból; h)-i) csápok: h) nőstény, i) hím. 


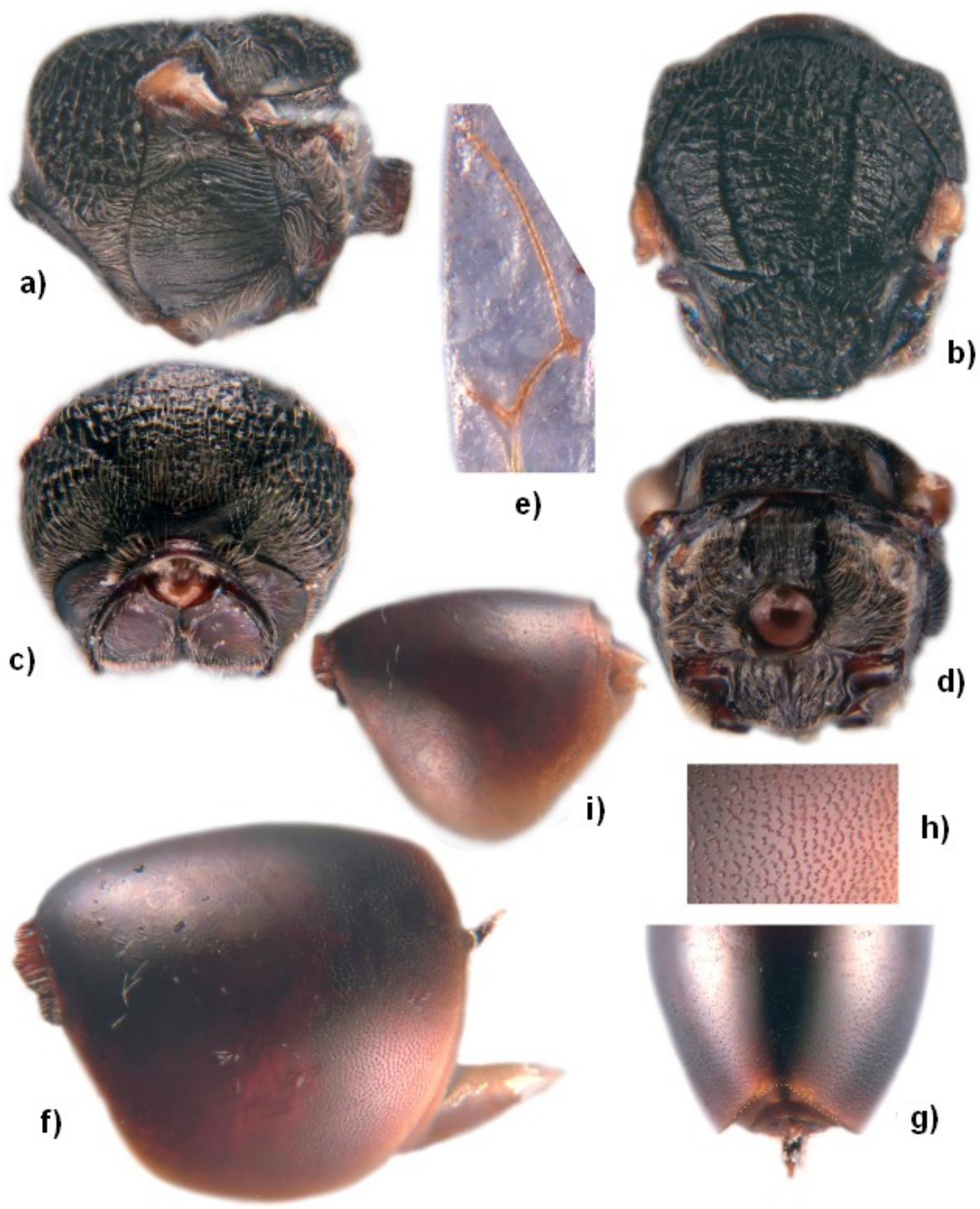

b)

)

23. ábra: Lithosaphonecrus dakengi: a)-h) nőstény példány: a) mesosoma laterális irányból, b) mesosoma dorzális irányból, c) mesosoma frontális irányból, d) metascutellum és propodeum poszterodorzális irányból, e) elülső szárny radiális sejtje, f) metasoma laterális irányból, g) metasoma poszterior része dorzális irányból, h) a metasoma 2-3. tergitjein a poszterior régiók felszíni mintázata; i) hím metasoma laterális irányból.

A mesoscutellum majdnem olyan hosszú mint amilyen széles, egységesen durva bőrszerü, rajta erős szabálytalan ráncok találhatóak. A scutellar fovea-k besüllyedtek, egymástól világosan elkülönülnek a köztük található nagyon keskeny median carina-nak köszönhetően. 
Sima és fényes aljukon erős párhuzamos hosszanti ráncok láthatóak. A mesopleuron recézett, párhuzamos hosszanti striákkal tarkított. A metapleural sulcus a mesopleuront annak felső $1 / 7$-ben éri el. A propodeum sima, szőrtelen, a central propodeal area-tól laterális irányban ritkásan álló rövid fehér sörtékkel; az propodeum oldalsó barázdája jól kivehető, teljes hosszán azonos szélességü; a propodeal area középső része sima és fényes, striák nélküli. A metascutellum nagyon keskeny, sokkal rövidebb mint a ventrális benyomódott terület; a metanotális vályú sima és fényes, rajta fehér sörték találhatóak; a propodeum légzőnyílásai keresztirányban tojásdadok, anterior határuk mentén erősen kiemelkedő borda található. A nucha sötétbarna, rajta hosszanti párhuzamos barázdaek láthatóak.

Az elülső szárny a testnél hosszabb, átlátszó, a szegélyén hosszú és sürün álló sörtékkel, radiális sejtjének hossza 2,6-szerese a szélességének; R1 sejtje megközelíti a szárny szegélyét; Rs majdnem egyenes, eléri a szárny szegélyét; az areolet nem kifejezetten látható; Rs és M nagyon halvány. A lábtőkarmok minden esetben egyszerüek, elkülönült bazális lebeny nélküliek.

A utótest hossza 1,3-szerese a magasságának és hosszabb a fej és középtest együttes hosszánál. A syntergite sima, fényes és csillogó, anterolaterális részén néhány fehér sörtével; poszterodorzális része erősen kimetszett. Felszínének poszteriori $1 / 4$-én sürü pontokból álló sáv található, mely eléri a ventrális szegélyt. Az ezt követő tergiteken és a hypopygium-on mikroméretü pontokkal tarkított; a hypopygium ventrális barázdaének kiemelkedő része nagyon rövid és keskeny, ventrális részén néhány rövid fehér sörtével. A test hossza 1,7-1,9 mm.

HÍM (5 példány adatai alapján). A nőstényhez hasonló megjelenésű, a csápok és a lábak beleértve a csípőket is - sárgák vagy sárgásbarnák; a csáp 13 flagellomerből áll, az F1 ívelt és apikális részén kiszélesedett, hossza 2,6-szerese az F2-nek; az F1 hossza 1,4-szerese az F2 és F3 együttes hosszának; az F4 hossza 1,2-szerese az F3 hosszának; az F4-F11 mérete közel azonos; a placoid sensilla-kat sztereomikroszkóppal nehezen lehet észrevenni. A test hossza 1,5-1,7 mm.

Életmód. A Lithosaphonecrus dakengi kifejlett példányait csak egyetlen gubacsból nevelték ki (TWb7=TWTb2), melynek leírása megtalálható a L. formosanus faj jellemzésénél. A gubacsokat április közepén gyüjtötték L. hancei-ról, a kifejlett inquilinek labor körülmények között közvetlenül a gyüjtés után megjelentek.

Elterjedés. Jelenleg kizárólag Tajvan Taichung megyéjéből ismert.

\section{Lithosaphonecrus yunnani Tang, Bozsó \& Melika}

24-25. ábrák

Típus példány. HOLOTÍPUS hím: KÍNA, (CHI-46) Yunnan tartomány, Lan Cang megye, Xiagudi, Lithocarpus fenestratus-ról gyüjtött ismeretlen rügygubacsból kinevelve (gubacs kódja: TWb7 = TWTb2), gubacsot gyüjtötték-2011.04.11., leg. Chang-Ti Tang. 
30 hím paratípust a haplotípussal megegyező cimkével láttak el. A hím holotípust és 10 hím paratípust az NMNS, 10 hím paratípust a PHMB, 5 hím paratípust az NCHU, 5 hím paratípust az USNM gyüjteményeiben helyeztek el.

Egyéb példányok. 28 hím: KÍNA, (CHI-46) Yunnan tartomány, Lan Cang megye, Xiagudi, Lithocarpus fenestratus-ról gyüjtött ismeretlen rügygubacsból kinevelve (gubacs kódja: TWb7 = TWTb2), gubacsot gyüjtötték-2011.04.11, leg. Chang-Ti Tang. Az összes példányt 96\%-os etanolba rakták és a PHMB gyüjteményében helyezték el.

Etimológia. A faj nevét arról a helyről (Yunnan tartomány, Kína) kapta ahol példányait első ízben begyüjtötték.

Diagnosztika. A kiszámított genetikai távolságok alapján legközelebbi rokon faja a L. huisuni (Bozsó és mtsi 2013). A két faj közti különbségek felsorolása megtalálható a fenti faj azonosításának ismertetésében. Morfológiailag a L. yunnani nagyon hasonlít a L. dakengi-re, azonban a L. yunnani esetében a gena erőteljes, szaggatott, szubparallel striákkal tarkított amelyek az összetett szemek mögött végződnek (24/d ábra) miközben a L. dakengi esetében a gena rövid striákkal tarkított amelyek elérik az összetett szemek alsó szegélyét és a gena szemek mögé eső része bőrszerű (22/d ábra). További adatok a L. formosanus azonosításánál felsoroltakban találhatóak

Leírás. HÍM (10 példány adatai alapján). A fej fekete, kivételt a arc alsó ventrális része jelent amely sötétbarna; clypeus, malar space és a csápok egyenletesen sárgásak vagy világos barnák; szájszervek, a maxilláris- és ajaktapogatók világos barnák; lábak egyenletesen sárgásbarnák; a szárnyakon pontosan kivehetőek a barna színü $\mathrm{R}+\mathrm{Sc}, \mathrm{R} 1+\mathrm{Sc}, \mathrm{M}, \mathrm{R} 1,2 \mathrm{r}$ és Rs erek, a többi ér halvány és nehezen követhetö; a középtest fekete; a utótest vörösesbarna, a hypopigium ventrális barázdae sokkal világosabb.

Az arc alsó része, a malar space és a clypeus viszonylag sürün álló fehér sörtékkel borított; a homlok, a szemek mögötti gena, a postgena, nyakszirt és vertex csak gyengén sertézett. A fej kerekded, frontális irányból a szélessége megegyezik a magasságával; a mesosománál valamivel szélesebb, dorzális irányból a szélessége 1,8-szerese a hosszúságának. A szemek magassága 1,5-szerese a malar space hosszának. A malar space malar sulcus nélküli, számos finom sugárirányú barázda figyelhető meg a clypeus és az összetett szemek között. A clypeus nagyon kicsi, bőrszerü, enyhén benyomódott, ventrális éle egyenes, nem szegélyezett; az episztomális barázda elmosódott és a clypeus zavartalanul csatlakozik a arc alsó részének közepéhez; az anteriorális tentorial pits-ek kicsik és halványak; a clypeo-pleurostomális vonal elmosódott. Az arc alsó részén a clypeus és a toruli, illetve a szemek alsó szegélye között nagyon finom striák láthatóak; központi kiemelkedő régiója halvány, rajta a toruli-ig érő striákkal. A 
homlok bőrszerü és fényes, rajta a toruli-tól induló és a középső pontszemig futó finom hosszanti striák, illetve olyan szabálytalan lefutású striák láthatóak melyek a toruli mindkét oldalán jelen vannak és az oldalsó pontszemekig futnak. A transfaciális távolság valamivel rövidebb a szemek magasságánál; a szem belső szegélye és a antennal torulus között mért távolság valamivel rövidebb, mint a torulus átmérője; a torulus átmérője 2,2-szerese a torulus-ok között mért távolságnak. POL hossza 1,7-szerese az OOL-nek és 2,1-szerese a LOL-nak; OOL hossza az oldalszemek távolságának 1,7-szerese. A vertex és a pontszemek közötti tér hálózatos vagy bőrszerü. A nyakszirt és a postgena egyenletesen sima, szőrtelen; occipital carina hiányzik. Frontális irányból nézve a gena a szem mögött nem szélesedik ki, felülete finoman bőrszerű, rajta néhány sörte található; erős szubparallel szaggatott striák futnak a malar space és a gena-t a postgena-tól élesen elválasztó barázda között. A postgenális híd hosszú, keskeny középső sávvá redukálódott; postgenal sulcus-ok teljes hosszukban egyesültek; poszteriorális tentorial pits-ek pontosan kivehetőek, a nyakszirt körüli terület jelentősen besüllyedt és sima, fényes felszínü. A csáp 13 flagellomerből áll, a pedicel hossza 1,9-szerese a szélességének, az F1 görbült és apikális részén kiszélesedik, hossza 2,6-szerese az F2 hosszának és 1,9-szerese a pedicel hosszának; F2 és F3 hossza megegyezik, az F4 és az azt követő flagellomerek hosszabbak az F3-nál; F12 és F13 hossza közel azonos; placoid sensilla-k tisztán láthatóak az F5-F13-on.

Laterális irányból a középtest valamivel hosszabb a magasságánál. Dorzális irányból a pronotum oldala lekerekített; felülete durván barázdált, oldalirányban néhány erős, szabálytalan lefutású stria található rajta amelyek között a felszín sima és fényes. Az pronotum laterális barázdája rövid, de mindig jelen van. A propleuron sima és fényes. A tegula anterior szegélye mentén mérve a mesoscutum szélesebb mint amilyen hosszú, rajta csak igen kevés fehér sörte látható amelyek a pronotum mentén sürübben helyezkednek el; felületét keresztirányú ráncok díszítik melyek a notauli között teljesek és a notaulus-tól a mesoscutum széléig futnak A ráncok közötti terület sima és fényes, a keresztirányú ráncok között néhány rövid, hosszanti lefutású szabálytalan anasztomózis található. A notauli teljesek és elérik a pronotumot, posteriori részükön csak nagyon kismértékben szélesednek ki, sima és fényes alján néhány párhuzamos ránc fut. A mesoscutum anteriorális részén futó párhuzamos vonalak jól láthatóak. A parapsidális vonalak keskenyek, elkülöníthetőek; parascutális barázda csak a tegula mentén található; a középső mesoscutal line határozottan látható, a mesoscutum félhosszáig kiterjed. A dorsoaxillar area durván bőrszerü és fényes; a lateroaxillar area hegyesszögben csatlakozik a dorsoaxillar area-hoz ami szintén durván börszerü, fényes. A mesoscutellum hosszabb mint amilyen széles, durván bőrszerü, rajta erős szabálytalan ráncok találhatóak. A scutellar fovea-k besüllyedtek, egymástól világosan elkülönülnek a köztük található nagyon keskeny median carina-nak 
köszönhetően. Sima és fényes aljukon erös párhuzamos hosszanti ráncok láthatóak. A mesopleuron felszínének 3/4-e hálózatos, rajta párhuzamos hosszanti striák kizárólag a dorzoposzteriorális negyedben láthatóak. A metapleural sulcus a mesopleuront annak felső 1/7ben éri el. A propodeum sima, szőrtelen; a trapéz alakú, poszteriorális részén keskenyebb és anterior részén szélesebb central propodeal area-tól laterális irányban ritkásan álló rövid fehér sörtékkel; az propodeum laterális barázdája jól kivehető, teljes hosszán azonos szélességü, a propodeum anterior végének irányában enyhén kifelé hajlik; a propodeal area középső része sima és fényes, striák nélküli. A metascutellum nagyon keskeny, sokkal rövidebb mint a ventrális benyomódott terület; a metanotális vályú sima és fényes, rajta fehér sörték találhatóak; a propodeum légzőnyílásai keresztirányban tojásdadok, anterior határuk mentén erősen kiemelkedő borda található. A nucha fekete, rajta hosszanti párhuzamos barázdaek láthatóak.

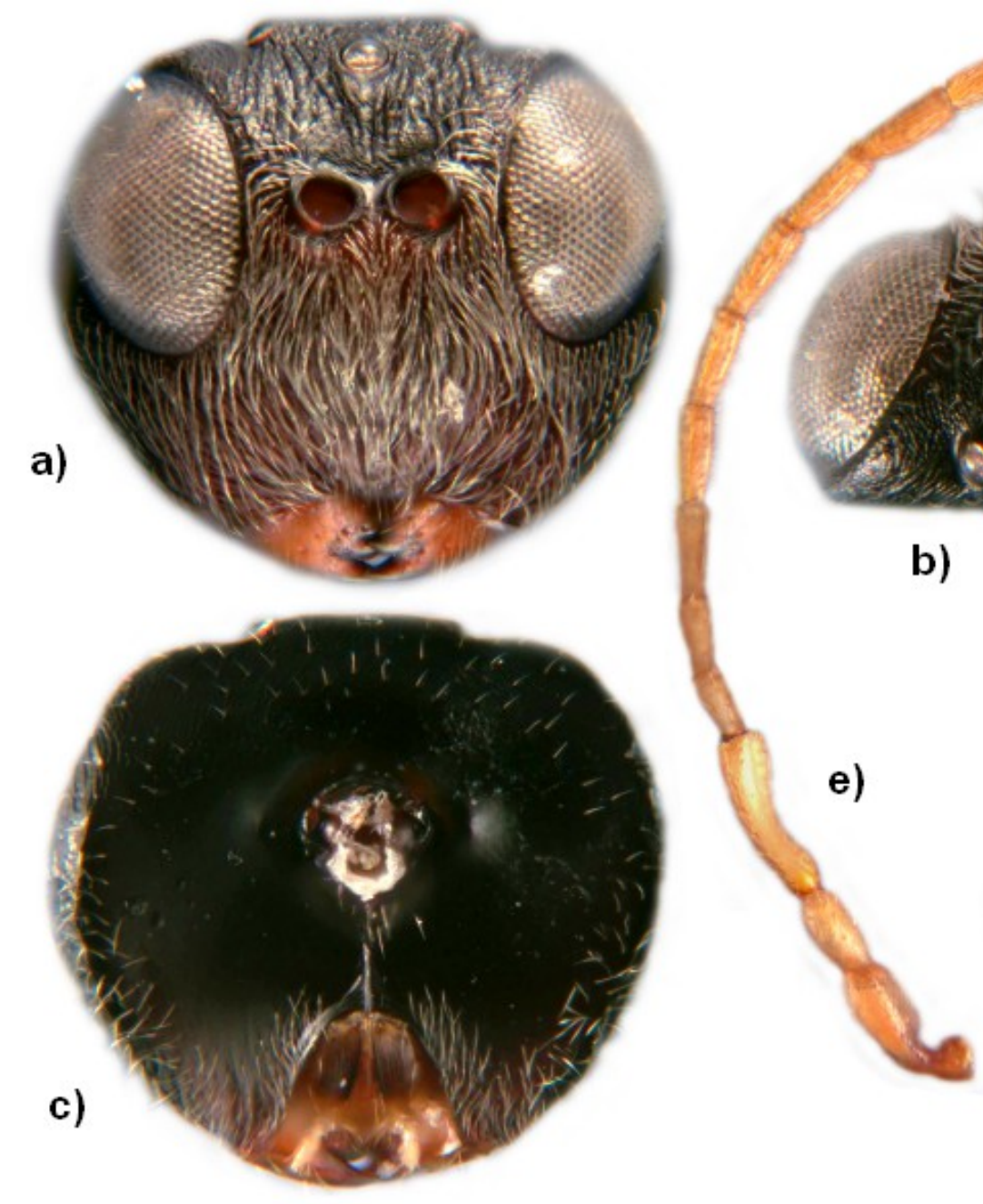

24. ábra: Lithosaphonecrus yunnani (új faj): a)-d) hím példány feje: a) frontális irányból, b) dorzális irányból, c) poszterior irányból; d) laterális irányból; e) hím példány csápja. 


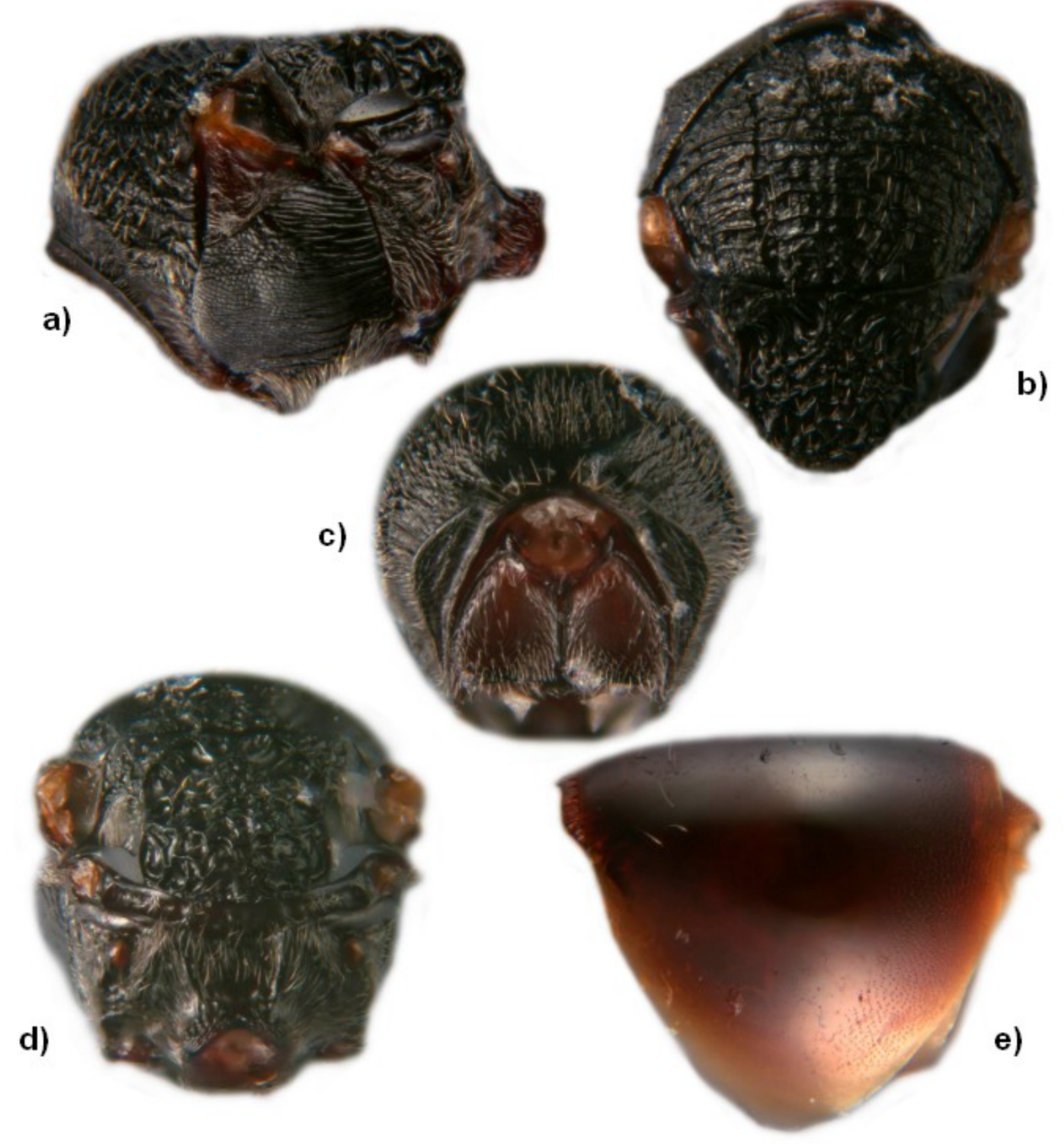

25. ábra: Lithosaphonecrus yunnani, hím példány: a) mesosoma laterális irányból, b) mesosoma dorzális irányból, c) mesosoma frontális irányból, d) metascutellum és propodeum poszterodorzális irányból, e) metasoma laterális irányból.

Az elülső szárny a testnél hosszabb, átlátszó, a szegélyén hosszú és sűrün álló sörtékkel, radiális sejtjének hossza 2,6-szerese a szélességének; R1 sejtje megközelíti a szárny szegélyét; Rs majdnem egyenes, eléri a szárny szegélyét; az areolet nem kifejezetten látható; Rs és M nagyon elmosódottak. A lábtökarmok minden esetben egyszerüek, elkülönült bazális lebeny nélküliek. 
A utótest hossza 1,3-szerese a magasságának és hosszabb a fej és középtest együttes hosszánál. A syntergite sima, fényes és csillogó, anterolaterális részén néhány fehér sörtével. Felszínének poszteriori $1 \frac{1}{4}$-én hálózatos sáv található, mely eléri a ventrális szegélyt. Az ezt követő tergitek mikroméretü pontokkal tarkítottak. A test hossza 1,9-2,1 mm.

Életmód. A Lithosaphonecrus yunnani kifejlett példányait a TWb7=TWTb2 kóddal jelölt rügygubacsból nevelték ki, melynek leírása megtalálható a L. formosanus faj jellemzésénél. A gubacsokat Kína Yunnan tartományából április közepén gyüjtötték L. fenestratus-ról, a kifejlett inquilinek labor körülmények között közvetlenül a gyüjtés után megjelentek.

Elterjedés. Jelenleg kizárólag Kína Lan Cang megyéjének Yunnan tartományából ismert.

\section{A Lithosaphonecrus génusz fajait a következőképpen azonosítjuk:}

1. Az összetett szemek mögött a gena a szemek alsó része mentén szélesebb, dorzális szegélyénél határozottan keskenyebb, poszterior része döntően függőleges lefutású (20/d ábra, a nyilak a gena szélességét jelzik). .2

Az összetett szemek mögött a gena a szemek alsó része mentén szintén szélesebb, azonban dorzális szegélyénél csak alig keskenyebb (22/d és 24/d ábrák, a nyilak a gena szélességét jelzik).

2. Frontális irányból a fej lekerekített (16/a, 16/d ábrák); a parapsidal vonalak láthatatlanok a harántirányú ráncok alatt (17/b ábra); a syntergite felszínének kizárólag a poszteriori $1 / 5$-én található mikroméretü pontokból álló sáv (17/f-g ábrák); a nőstény csápok $\mathrm{F} 1$ hossza 1,8-szerese az F2 hosszának (16/g ábra); a hím csápok F1 hossza 3,0-szorosa az F2 hosszának (16/h ábra). formosanus

Frontális irányból a fej enyhén trapezoid (20/a, 20/e ábrák); a parapsidal vonalak keskenyek, elkülöníthetőek (21/b ábra); a syntergite felszínének legalább a poszteriori 1/4-én szélesebb, hálózatosan elhelyezkedő pontokból álló sáv található (21/g-h ábrák); a nőstény csápok F1 hossza 1,5-szerese az F2 hosszának (20/h ábra); a hím csápok F1 hossza 2,6-szerese az F2 hosszának (20/i ábra).

huisuni

3. A fej és/vagy a középtest részben barna; az összetett szemek mögött a gena bőrszerü, szubparallel stria-k futnak a malar space-től a szemek alsó szegélyéig (22/d ábra); a nyakszirt és részben a postgena felszíne is bőrszerü vagy hálózatos mintázat borítja ( $22 / \mathrm{c}, 22 / \mathrm{g}$ ábrák); a hím csápokon az F1 hossza 1,9-szerese az F2-nek és 1,5-szerese a pedicel hosszának 
(22/i ábra); a nőstény csápokon az F1 hossza 1,9-szerese az F2 hosszának, valamint F2 alig

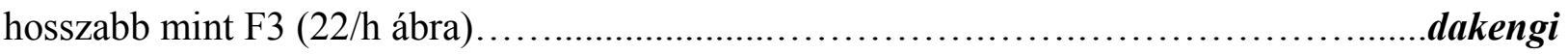

A fej és a középtest fekete; a gena-n szubparallel stria-k futnak a malar space-től a szemek mögé (24/d ábra); a nyakszirt és a postgena felszíne is sima és szőrtelen (24/c ábra); a hím csápokon az F1 hossza 2,6-szerese az F2-nek és 1,9-szerese a pedicel hosszának (24/e ábra); a nőstény jelenleg ismeretlen. yunnani 


\subsection{Gubacsdarázs gazda kapcsolatok}

Dolgozatom ezen fejezetében kvalitatíve elemzem az tanulmányozott egyedek, illetve a filogenetikai vizsgálatunkban korábban elkülönített Saphonecrus vagy Saphonecrus-közeli kládok gubacsgazda asszociációit. Elemzésünkben minden esetben egyetlen gubacsból kinevelt egyetlen inquilin példány gazda kapcsolatáról van szó, ezért a fejezetben szereplő előzetes adataink csak tájékoztató jellegüek, a gubacsgazda asszociációk statisztikai elemzése jelenleg folyamatban van. A fejezetben szereplő eredményeket még nem publikáltuk.

A tanulmányunkban résztvevő taxonok gazdagubacs kapcsolatait a 3. táblázatban foglaltam össze. Abban az esetben ha a gazda faj ismert volt akkor a táblázat megfelelő cellájában feltüntettem annak fajnevét. Mivel vizsgálatunkban az eddig még be nem azonosított Kelet-Palearktikus egyedek gubacsgazda fajait - a Saphonecrus sp. 50-51 példányok kivételével - még nem ismerjük ezért esetükben a gubacsoknak azt a kódját tüntettem fel amelyet az inquilin kinevelése során rendeltek hozzájuk. Az előzetes molekuláris vizsgálatok alapján az itt felsorolt gubacsok a Cynipidae családba tartoznak (Dr. James Nicholls, Edimburgi Egyetem, szóbeli közlés). Saphonecrus sp. 34 esetében nincsenek megbízható adatok arról, hogy azt milyen gubacsból nevelték ki, ezért adatait a táblázatban nem tudtam feltüntetni.

Megpróbáltunk a gazdagubacsok 4 típusának (levél-, szár-, rügy- és barkagubacs) eloszlását fillogenetikára leképezni (26.ábra). A Nyugat-Palearktikus Saphonecrus fajokon belül a „barbotini” kládot alkotó, évente két generációval rendelkező $S$. barbotini és $S$. gallaepomiformis kizárólag a Plagiotrochus génusz fajait, ezen belül is különösképpen a $P$. britaniae Barbotin és $P$. coriaceus (Mayr) vesszőkön fejlődő fás gubacsait támadják meg (Pujade-Villar és Nieves-Aldrey 1990).

A „connatus” kládot alkotó Nyugat-Palaearktikus S. connatus irodalmi adatok szerint néhány Andricus fajon kívül a Callirhytis glandium (Giraud), Cynips quercusfolii (L.), Neuroterus anthracinus (Curtis) és N. quercusbaccarum (L.) gubacsaiban egyaránt fejlődhet. A vizsgált példányunkat Andricus testaceipes Hartig szárgubacsából nevelték ki. A két KeletPalaearktikus fajt a Callirhytis hakonensis (Ashmead) (= Andricus symbioticus Kovalev) aszexuális gubacsából neveltük ki.

Az „undulatus” kládban az évente egy generációval rendelkezö, monofiletikus csoportot alkotó Saphonecrus haimi és S. undulatus az Aphelonyx cerricola (Giraud), Cerroneuroterus lanuginosus (Giraud), Chilaspis nitida (Giraud), Ch. israeli (Sternlicht), Pseudoneuroterus saliens (Kollar) által indukált, valamint a Synophrus politus által módosított gubacsokban fejlődhet (Pujade-Villar és mtsi 2003, Melika 2006). 


\begin{tabular}{|c|c|c|}
\hline Taxon/minta neve & $\begin{array}{l}\text { Cínipid gubacs } \\
\text { helyzete }\end{array}$ & Cynipid gubacsgazda faj \\
\hline Saphonecrus sp. 2 (JP02) & levélgubacs & spJPI2 (=TWTI7) \\
\hline Lithosaphonecrus dakengi (sp.4) & rügygubacs & TWTb2 (has onló a spTWb7-hez) \\
\hline Saphonecrus sp. 9 (JP02) & levélgubacs & spJPI2 (=TWT17) \\
\hline Saphonecrus sp.11 & levélgubacs & spTW14 \\
\hline Lithosaphonecrus huisuni (sp.13) & rügygubacs & spTWb7 \\
\hline Saphonecrus sp.15 & szárgubacs & TWTs 2 \\
\hline Saphonecrus sp. 18 & levélgubacs & spJPI5 \\
\hline Saphonecrus sp. 21 & levélgubacs & TWT112 \\
\hline Saphonecrus sp. 23 & levélgubacs & TWTI10 \\
\hline Saphonecrus sp. 27 & levélgubacs & AGWP-Morpho45 \\
\hline Lithosaphonecrus formosanus (sp. 29) & szárgubacs & spTWs5 \\
\hline Saphonecrus sp. 30 & rügygubacs & spTWb7 \\
\hline Lithosaphonecrus yunnani (sp. 31) & rügygubacs & spTWb7 \\
\hline Saphonecrus sp. 32 & rügygubacs & spTWb7 \\
\hline Saphonecrus sp. 34 & - & - \\
\hline Saphonecrus sp. 35 & levélgubacs & TWTI10 \\
\hline Saphonecrus sp. 36 & szárgubacs & spTWs 5 \\
\hline $\begin{array}{c}\text { Saphonecrus shirokashicola (sp.44) } \\
\text { (JP03) }\end{array}$ & levélgubacs & spJPl4 \\
\hline Saphonecrus sp. 46 & szárgubacs & TWTs 2 \\
\hline Saphonecrus sp. 48 & szárgubacs & TWTs5 \\
\hline Saphonecrus sp. 49 & szárgubacs & spTWs5 \\
\hline Saphonecrus sp. 50 & levélgubacs & Callirhytis hakonensis \\
\hline Saphonecrus sp. 51 & levélgubacs & Callirhytis hakonensis \\
\hline Saphonecrus sp. 56 & szárgubacs & TWTs2 \\
\hline $\begin{array}{c}\text { Saphonecrus shirokashicola (sp.57) } \\
\text { (JP03) }\end{array}$ & levélgubacs & AGWP-Morpho45 \\
\hline Saphonecrus sp. 58 & levélgubacs & spJPI2 (=TWT17) \\
\hline Saphonecrus shirakashii (JP01) & levélgubacs & spJPI5 \\
\hline Saphonecrus connatus & szárgubacs & Andricus testaceipes \\
\hline Saphonecrus undulatus & szárgubacs & Aphelonyx cerricola \\
\hline Saphonecrus haimi & barkagubacs & Chilaspis nitida \\
\hline Saphonecrus gallaepomiformis & rügygubacs & Plagiotrochus sp. \\
\hline Saphonecrus barbotini & rügygubacs & Plagiotrochus britaniae \\
\hline
\end{tabular}

3. táblázat: A vizsgált Saphonecrus és Saphonecrus-közeli példányok gazdagubacs kapcsolatai. Vastag betükkel kiemeltem a Kelet-Palearktikus egyedeket.

Az elemzésünkbe bevont Saphonecrus haimi-t a Ch. nitida barkagubacsából, a S. undulatus-t pedig az Aphelonyx cerricola szárgubacsából nevelték ki. A többi leíratlan Kelet-Palearktikus kládtól a filogenetikai elemzés eredményeivel egybevágóan a gazdagubacs típusa alapján is 
élesen elkülönül a „Lithosaphonecrus” klád, fajainak begyüjtött példányai rügygubacsban és szárgubacsban fejlödtek. A L. dakengi/L. formosanus és L. huisuni/L. yunnani kládokat sem a gubacsoknak a növényen elfoglalt helyzete (26.ábra), sem a tojásrakás szempontjából feltételezhetően jelentőséggel bíró felszíni mintázat alapján (28.ábra) nem sikerült egymástól egyértelmüen elhatárolnunk. Mindkét esetben úgy tünik, hogy a L. formosanus faj példánya eltér a másik három faj vizsgált egyedétől ugyanis lárvája a L. formosanus leírásában is ismertetett, „tengeri sünre” hasonlító szárgubacsban fejlődött ki (30/a ábra). Ezzel szemben a másik 3 faj példányai szabálytalan felszínü, lapos, kerek rügygubacshoz társíthatóak (29/a ábra).

A ,shirokashicola” klád egyedei a gazdagubacsaik típusa (26.ábra) és a gubacsok felszíne (28.ábra) alapján, a gubacsok változatos alakja ellenére is egységes csoportot alkotnak. Azonban ha figyelembe vesszük a levélgubacsoknak a levélen elfoglalt pozícióját is (27.ábra) akkor a filogenetikai vizsgálat eredményével egybevágóan a kládon belül el tudunk különíteni két csoportot. A Saphonecrus sp. 2 és sp. 9 fajokhoz kapcsolható 2-3 mm átmérőjü kis kerek gubacsok (30/b ábra) kizárólag a levél felszínén, míg a klád többi tagjához asszociálódott levélgubacsok - a Saphonecrus shirokashicola (sp.44) (30/c ábra) kivételével - a levél fonákján helyezkedtek el. A Saphonecrus shirokashicola sp.57 és Saphonecrus sp.27 példányokhoz társítható kisméretü, barna tojás alakú gubacsok (30/i ábra) a fóér egyik oldalán voltak. A Saphonecrus sp. 18-hoz rendelhető 3X1mm-es megnyúlt, végükön elkeskenyedő gubacsok (30/d ábra) szintén a levél erei mentén képződtek.

A „shirokashii” és „Saphonecrus\#1” kládoktól a filogenetikai vizsgálat eredményéhez hasonlóan a gazdagubacsok típusa alapján el tudtuk különíteni a „Saphonecrus\#2” kládot, melynek tagjai rügy- és szárgubacsokban fejlödtek, a csoport egyetlen tagját sem tudtuk levélgubacshoz társítani (26.ábra). Igaz, hogy mint említettem a Saphonecrus sp. 34-röl nincsenek jelenleg ilyen jellegü adataink de feltételezhetjük, hogy ez a példány szintén a fenti típusok valamelyikéhez társítható. A kláddal kapcsolatban érdemes még megemlíteni, hogy a Saphonecrus sp. 36 mind a gubacs növényen elfoglalt helyzete, mind a gubacs felszíne alapján elkülöníthető a másik két egyedtől mivel ebben az esetben is a L. formosanus-nál említett gubacstípusban (30/a ábra) fejlődött ki az inquilin lárva. Ezzel szemben a Saphonecrus sp. 30 és sp. 32 példányokat egy 10X15mm-es lapos korong alakú, egyenetlen felszínü, középen enyhén benyomódó rügygubacsból nevelték ki (29/a ábra).

Eredményeink alapján a „Saphonecrus \#1” klád a gubacsok típusa (26.ábra) és felszíne (28.ábra) alapján olyan egységes csoportot alkotott amely a levélgubacsoknak a levélen elfoglalt helyzete alapján (27.ábra) egyértelmüen elkülönült a „shirakashii” kládtól. A leszármazási vonalhoz társítható szabálytalan alakú, megduzzadt gubacsok (30/g ábra) a levelek tövénél vagy 


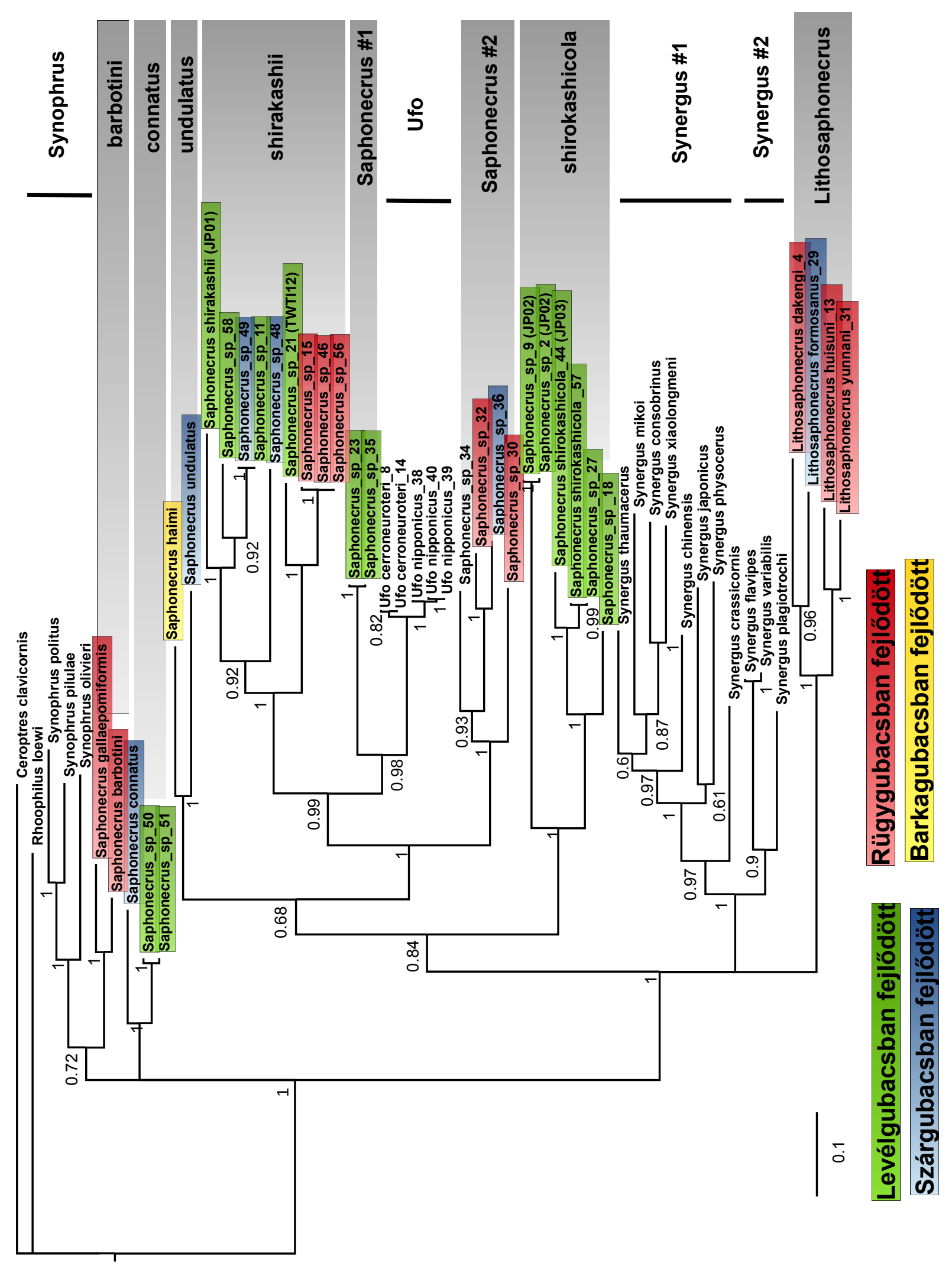

26. ábra: A vizsgált Saphonecrus és Saphonecrus-közeli példányok gazdagubacs kapcsolatai a gubacsok növényen elfoglalt helyzete alapján csoportosítva. Szürke háttérrel a dolgozatom tárgyát képező kládokat emeltem ki. 


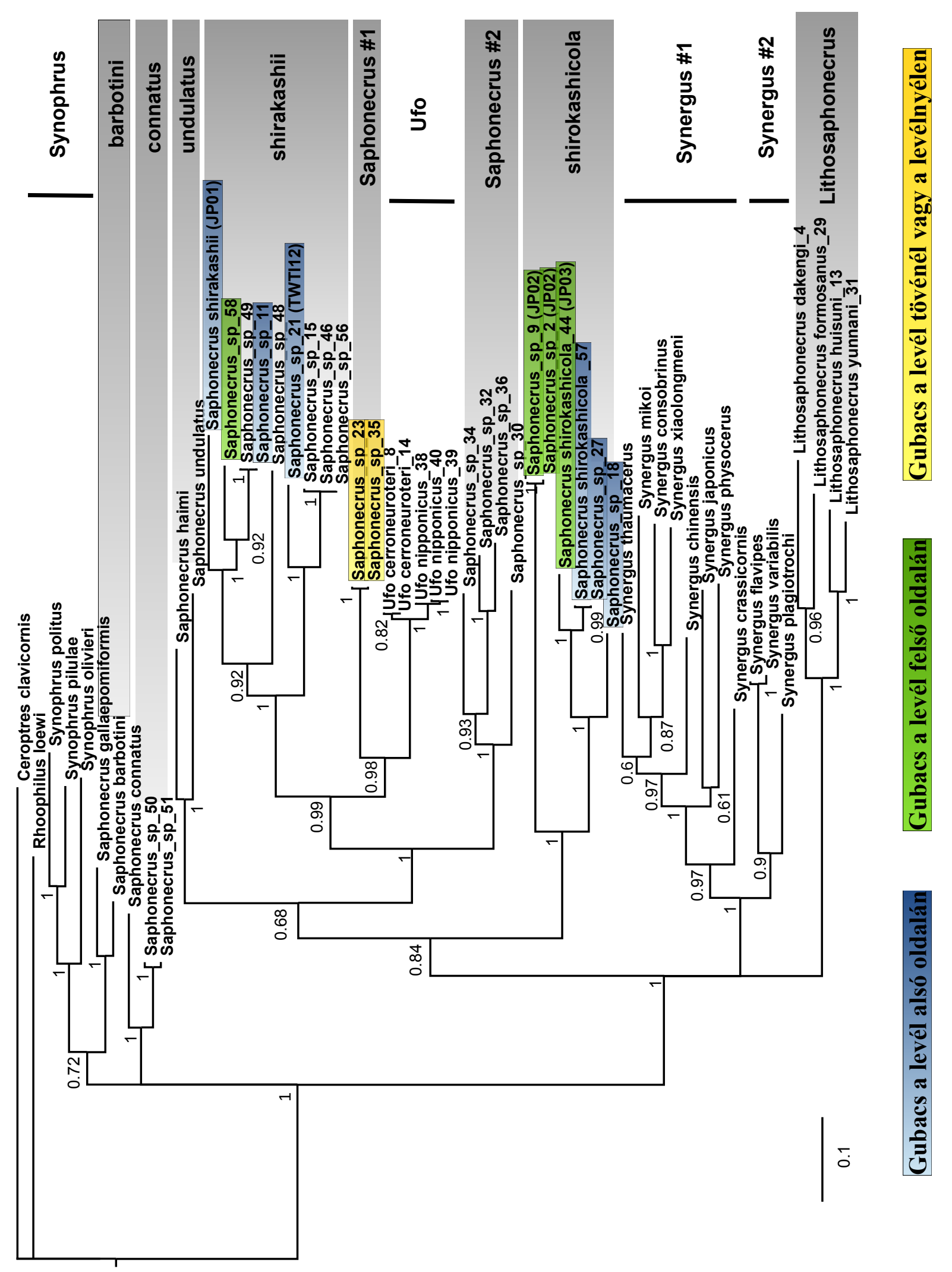

27. ábra: A vizsgált Saphonecrus és Saphonecrus-közeli példányok gazdagubacs kapcsolatai a levélgubacsoknak a leveleken elfoglalt helyzete alapján csoportosítva. Szürke háttérrel a dolgozatom tárgyát képezö kládokat emeltem ki. 


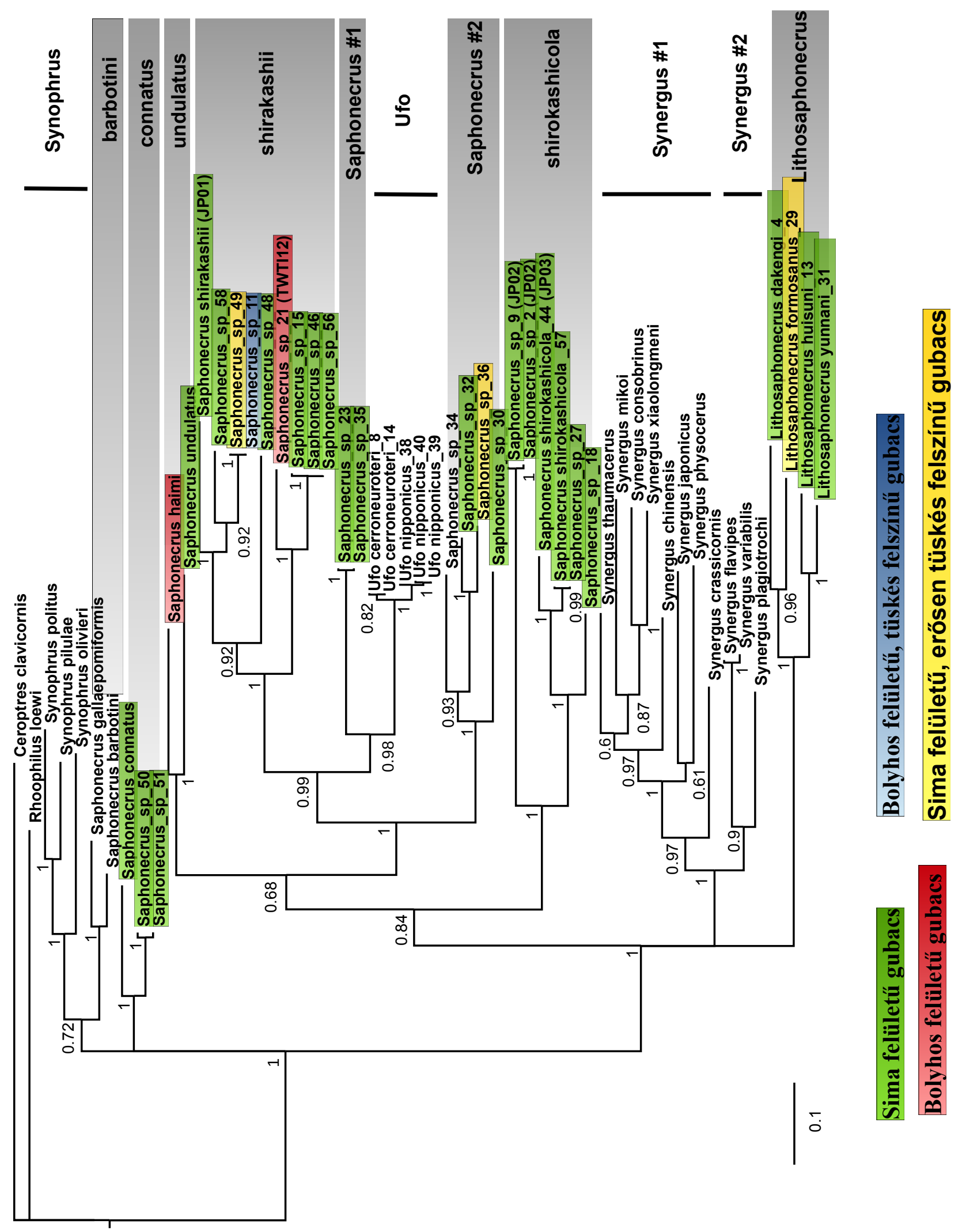

28. ábra: A vizsgált Saphonecrus és Saphonecrus-közeli példányok gazdagubacs kapcsolatai a gubacsok felszíni mintázata alapján csoportosítva. Szürke háttérrel a dolgozatom tárgyát képező kládokat emeltem ki. 
a levélnyélen helyezkedtek el.

A ,shirakashii” kládot vizsgált genetikai tulajdonságaik és gubacsgazda kapcsolataik alapján is egyértelmüen felbonthattuk két csoportra. Az elsőbe a Saphonecrus sp.21 valamint a Saphonecrus sp. 15, sp. 46 és sp. 56 egyedeket sorolhattuk. A Saphonecrus sp. 21 mind a gubacs felszíne (28.ábra), mind a növényen elfoglalt helyzete (26.ábra) alapján alapvetően eltért a többi egyedtől mivel azok sima felszínü rügygubacsokban (29/b ábra) fejlődtek, ezzel szemben a 21-es példány a levelek fonákján kialakult, bolyhos felszínű gubacsban (30/h ábra) fejlődött ki. A felállított másik csoporton belül egyértelmü alcsoportokat nem tudtunk felállítani a gubacsok gazdanövényen elfoglalt helyzete (26-27.ábrák) alapján, keverten fordulnak elő benne a különböző helyzetű levél- és szárgubacsokhoz asszociálódott egyedek. Érdemes azonban megemlíteni a 49-es és 11-es példányokat mivel ezek a többi, sima felszínű gubacsokhoz (29/c, 30/b ábrák) társult egyeddel ellentétben egy külön leszármazási vonalat alkotva sima vagy bolyhos felszínü, de mindenképpen tüskékkel díszített gubacsokba (30/a, 30/f ábrák) rakott tojásokból fejlődtek ki.

a)

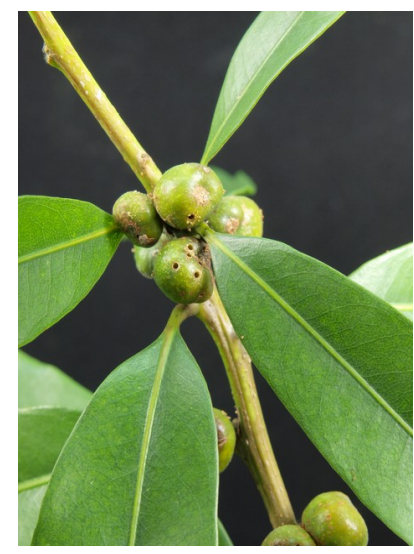

Indet Cynipidae spTWTb2-L. hancei Lithocarpus b)

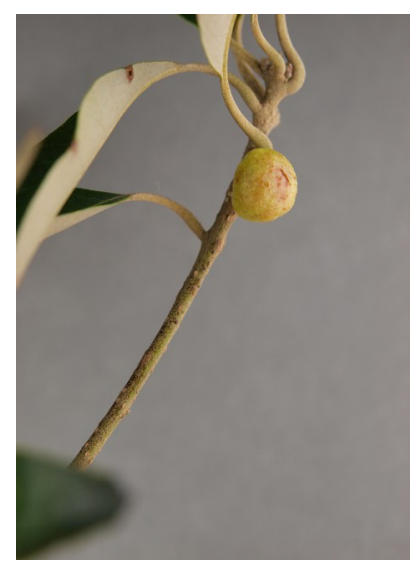

Indet Cynipidae

TWTs2-C. hypophaea

Quercus subg.

Cyclobalanopsis c)

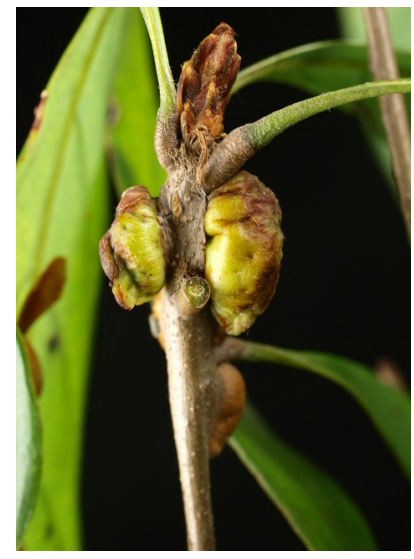

Indet Cynipidae TWTs5-C. pachyloma Quercus subg. Cyclobalanopsis

29. ábra: A vizsgálatunk során felhasznált, Kelet-Palearktikumból begyüjtött azonosítatlan rügygubacs (a) és szárgubacsok (b, c). A képek alatt feltüntettem a gubacs kódját, illetve a gazdanövény faját (vastag betükkel kiemelve) valamint a gazdanövény nemzetségét. (forrás: C.T. Tang) 
a)

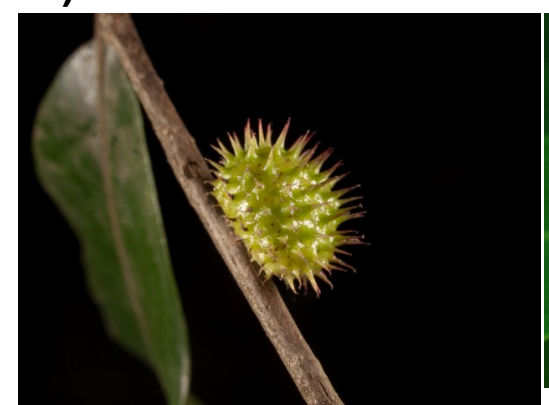

Indet Cynipidae spTWs5-L. konishii Lithocarpus b)

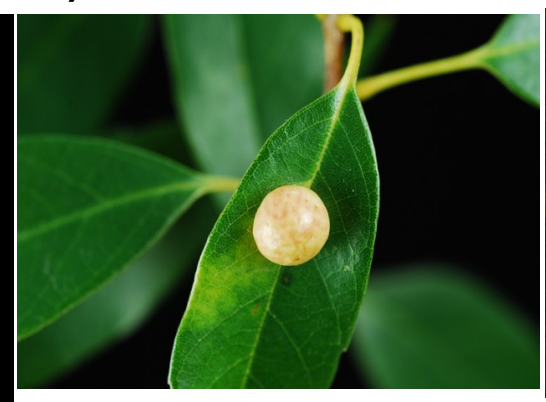

Indet Cynipidae spJPI2-C. longinux

Quercus subg.

Cyclobalanopsis c)

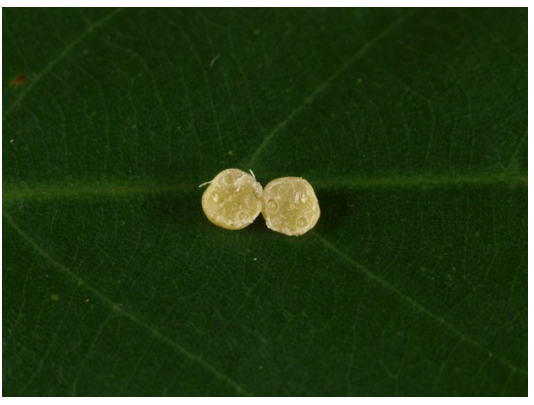

Indet Cynipidae spJPI4-C. glauca

Quercus subg.

Cyclobalanopsis d)

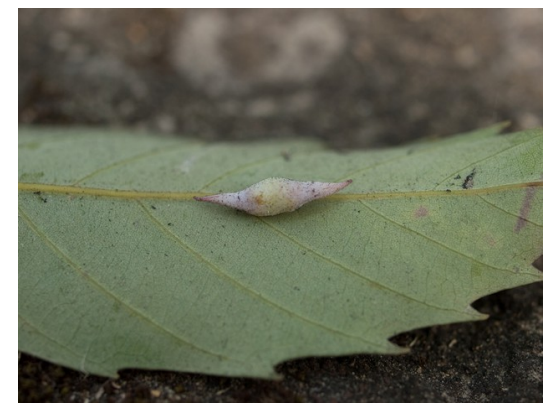

Indet Cynipidae spJPI5-C. glauca

Quercus subg.

Cyclobalanopsis

g)

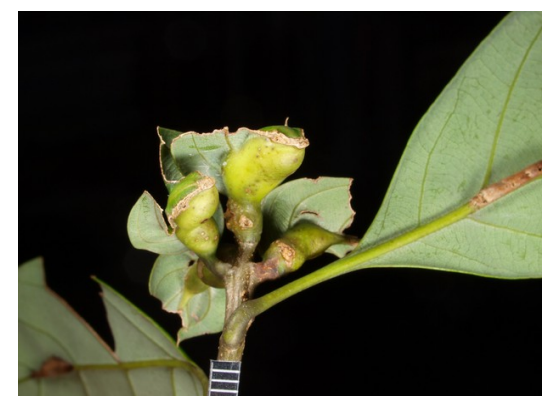

Indet Cynipidae TWTI10-C. glauca

Quercus subg.

Cyclobalanopsis e)

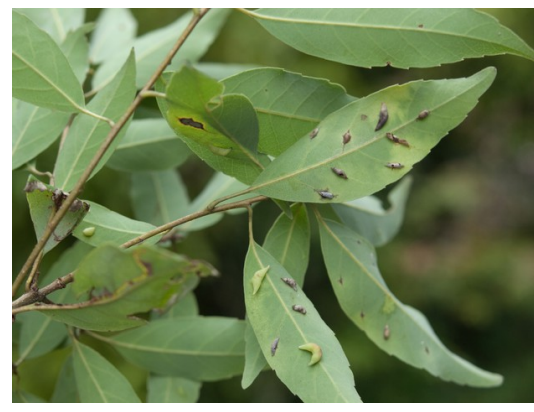

Indet Cynipidae spJPI5-C. globosa

Quercus subg.

Cyclobalanopsis

h)

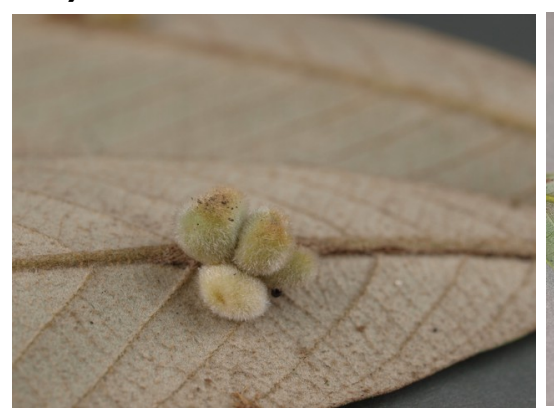

Indet Cynipidae TWT112-C. gilva Quercus subg. Cyclobalanopsis f)

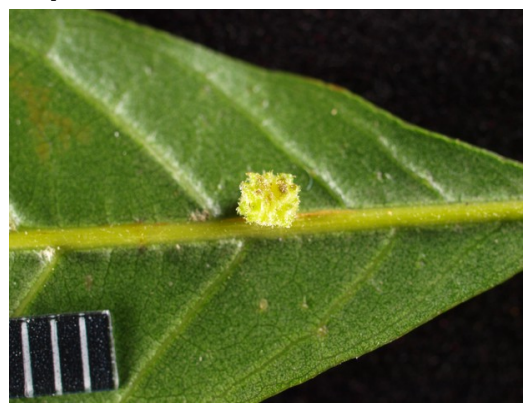

Indet Cynipidae spTW14-C. morii

Quercus subg.

Cyclobalanopsis

i)

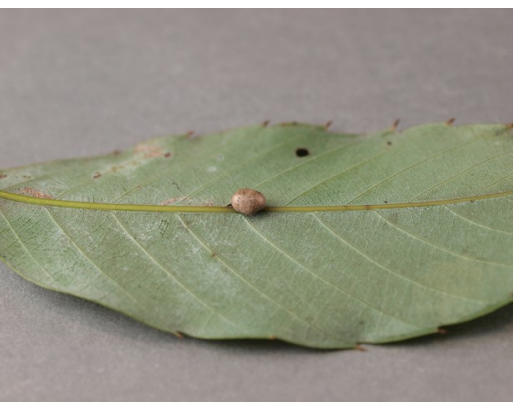

Indet Cynipidae AGWP-Morpho45

C. salicina/C. glauca

Quercus subg.

Cyclobalanopsis

30. ábra: A vizsgálatun során felhasznált, Kelet-Palearktikumból begyüjtött azonosítatlan szárgubacs (a) és levélgubacsok (b-i). A képek alatt feltüntettem a gubacs kódját, illetve a gazdanövény faját (vastag betúkkel kiemelve) valamint a gazdanövény nemzetségét. (forrás: C.T. Tang) 


\subsection{Gazdanövény kapcsolatok}

Vizsgálatunk célja az volt, hogy megpróbáljunk filogenetikai kapcsolataik alapján a vizsgált példányok, illetve kládok gazdaváltására következtetni (Pénzes és mtsi 2012). A vizsgált Saphonecrus fajok ismert gazdanövény kapcsolatait a 4. táblázatban foglaltam össze, majd megvizsgáltam, hogy vajon esetükben az egyes leszármazási vonalakon történtek-e gazdanövény váltások. Mivel filogenetikai elemzésünkben a testvér csoport kapcsolatok bizonytalanok ezért a következtetés is csak kvalitatívan történt.

Az inquilin fajok gazdanövény asszociációik alapján a Fagaceae család két nemzetsége (Quercus, Lithocarpus), a Quercus nemzetségnek két alnemzetsége (Quercus, Cyclobalanopsis), a Quercus alnemzetségnek pedig két szekciója (Quercus, Cerris) között szóródtak melyek eloszlását a 31. ábrán szemléltettem. A taxon két korán elágazó Nyugat-Palaearktikus ága a Quercus alnemzetség különböző szekcióival asszociálódott: a) a "barbotini” csoport ( $S$. barbotini és S. gallaepomiformis) a Synophrus fajokhoz hasonlóan (Melika és mtsi 2012) a Cerris tölgyszekció egy-egy fajához; b) a "connatus" csoport (S. connatus és a két eddig még leíratlan Kelet-Palaearktikus faj) pedig a Quercus tölgyszekció két fajához társult.

Az „undulatus”, „shirakashii”, „Saphonecrus\#1”, „Saphonecrus \#2” és „shirokashicola” csoportokat magában foglaló kládból három csoport a Cyclobalanopsis algénuszhoz társult (,shirakashii”, „Saphonecrus\#1”, „shirokashicola”). A Saphonecrus shirakashii-t és a nyolc eddig még le nem írt tajvani fajt tartalmazó „shirakashii” klád, illetve a két szintén leíratlan tajvani fajt magában foglaló „Saphonecrus \#1” klád egyaránt jól elhatárolható csoportokat alkotott. Ezek a csoportok egyértelműen elkülöníthetőek voltak a „shirakoshicola” kládtól ami azt sugallhatja, hogy a Cyclobalanopsis alnemzetség irányában legalább kettő vagy három gazdanövény váltás történhetett a csoport evolúciója során. Ennek alternatívájaként ez a mintázat úgy is magyarázható ha azt feltételezzük, hogy a "shirakashii”, „Saphonecrus\#1” és "shirokashicola" kládok közös ősének a Cyclobalanopsis alnemzetségbe tartozott a gazdanövénye és törzsfejlödésük során gazdaváltások következhettek be melyek a kládok eltávolodását eredményezhették. Az Ufo génusz filogenetikai helyzete utóbbi feltételezésünket igazolhatja, mivel fajai kizárólag a Cerris tölgyszekció tagjaihoz kapcsolódtak: a Q. acutissima Japánban, a $Q$. variabilis Japánban, Koreában és Tajvanon lehet a gazdanövényük (Melika és mtsai 2012). Ha csak az Ufo, „Saphonecrus \#1” és „shirakashii” kládokat vesszük figyelembe akkor a Cyclobalanopsis szubgénuszról a Quercus szubgénusz Cerris szekciójára történt gazdanövény váltásnak a legnagyobb a valószínűsége. További példa lehet erre az „undulatus” csoport filogenetikai helyzete, melynek fajai (S. haimi, S. irani és $S$. undulatus) szintén a Cerris 


\begin{tabular}{|c|c|c|}
\hline \multirow{2}{*}{ Taxon/minta neve } & \multicolumn{2}{|r|}{ Gazdanövény } \\
\hline & nemzetsége & faja \\
\hline Saphonecrus sp. 2 (JP02) & Cyclobalanopsis & Cyclobalanopsis longinux \\
\hline Lithosaphonecrus dakengi (sp.4) & Lithocarpus & Lithocarpus hancei \\
\hline Saphonecrus sp. 9 (JP02) & Cyclobalanopsis & Cyclobalanopsis longinux \\
\hline Saphonecrus sp.11 & Cyclobalanopsis & Cyclobalanopsis morii \\
\hline Lithosaphonecrus huisuni (sp.13) & Lithocarpus & Lithocarpus glabra \\
\hline Saphonecrus sp.15 & Cyclobalanopsis & Cyclobalanopsis hypophaea \\
\hline Saphonecrus sp. 18 & Cyclobalanopsis & Cyclobalanopsis globosa \\
\hline Saphonecrus sp. 21 & Cyclobalanopsis & Cyclobalanopsis gilva \\
\hline Saphonecrus sp. 23 & Cyclobalanopsis & Cyclobalanopsis glauca \\
\hline Saphonecrus sp. 27 & Cyclobalanopsis & Cyclobalanopsis salicina \\
\hline Lithosaphonecrus formosanus (sp. 29) & Lithocarpus & Lithocarpus konishii \\
\hline Saphonecrus sp. 30 & Lithocarpus & Lithocarpus fenestratus \\
\hline Lithosaphonecrus yunnani (sp. 31) & Lithocarpus & Lithocarpus fenestratus \\
\hline Saphonecrus sp. 32 & Lithocarpus & Lithocarpus konishii \\
\hline Saphonecrus sp. 34 & Lithocarpus & Lithocarpus dodonaeifolius \\
\hline Saphonecrus sp. 35 & Cyclobalanopsis & Cyclobalanopsis glauca \\
\hline Saphonecrus sp. 36 & Lithocarpus & Lithocarpus konishii \\
\hline $\begin{array}{c}\text { Saphonecrus shirokashicola (sp.44) } \\
\text { (JP03) }\end{array}$ & Cyclobalanopsis & Cyclobalanopsis glauca \\
\hline Saphonecrus sp. 46 & Cyclobalanopsis & Cyclobalanopsis hypophaea \\
\hline Saphonecrus sp. 48 & Cyclobalanopsis & Cyclobalanopsis pachyloma \\
\hline Saphonecrus sp. 49 & Cyclobalanopsis & Cyclobalanopsis morii \\
\hline Saphonecrus sp. 50 & Quercus (Quercus szekció) & Quercus dentata \\
\hline Saphonecrus sp. 51 & Quercus (Quercus szekció) & Quercus dentata \\
\hline Saphonecrus sp. 56 & Cyclobalanopsis & Cyclobalanopsis hypophaea \\
\hline Saphonecrus shirokashicola (sp.57)(JP03) & Cyclobalanopsis & Cyclobalanopsis salicina és C. glauca \\
\hline Saphonecrus sp. 58 & Cyclobalanopsis & Cyclobalanopsis longinux \\
\hline Saphonecrus shirakashii (JP01) & Cyclobalanopsis & Cyclobalanopsis glauca és C. globosa \\
\hline Saphonecrus connatus & Quercus (Quercus szekció) & Q.petraea \\
\hline Saphonecrus undulatus & Quercus (Cerris szekció) & Q. cerris \\
\hline Saphonecrus haimi & Quercus (Cerris szekció) & Q. cerris \\
\hline Saphonecrus gallaepomiformis & Quercus (Cerris szekció) & Q.ilex \\
\hline Saphonecrus barbotini & Quercus (Cerris szekció) & Q. coccifera \\
\hline
\end{tabular}

4. táblázat: A vizsgált Saphonecrus és Saphonecrus-közeli példányok gazdanövény kapcsolatai. Vastag betükkel kiemeltem a Kelet-Palearktikus egyedeket. 


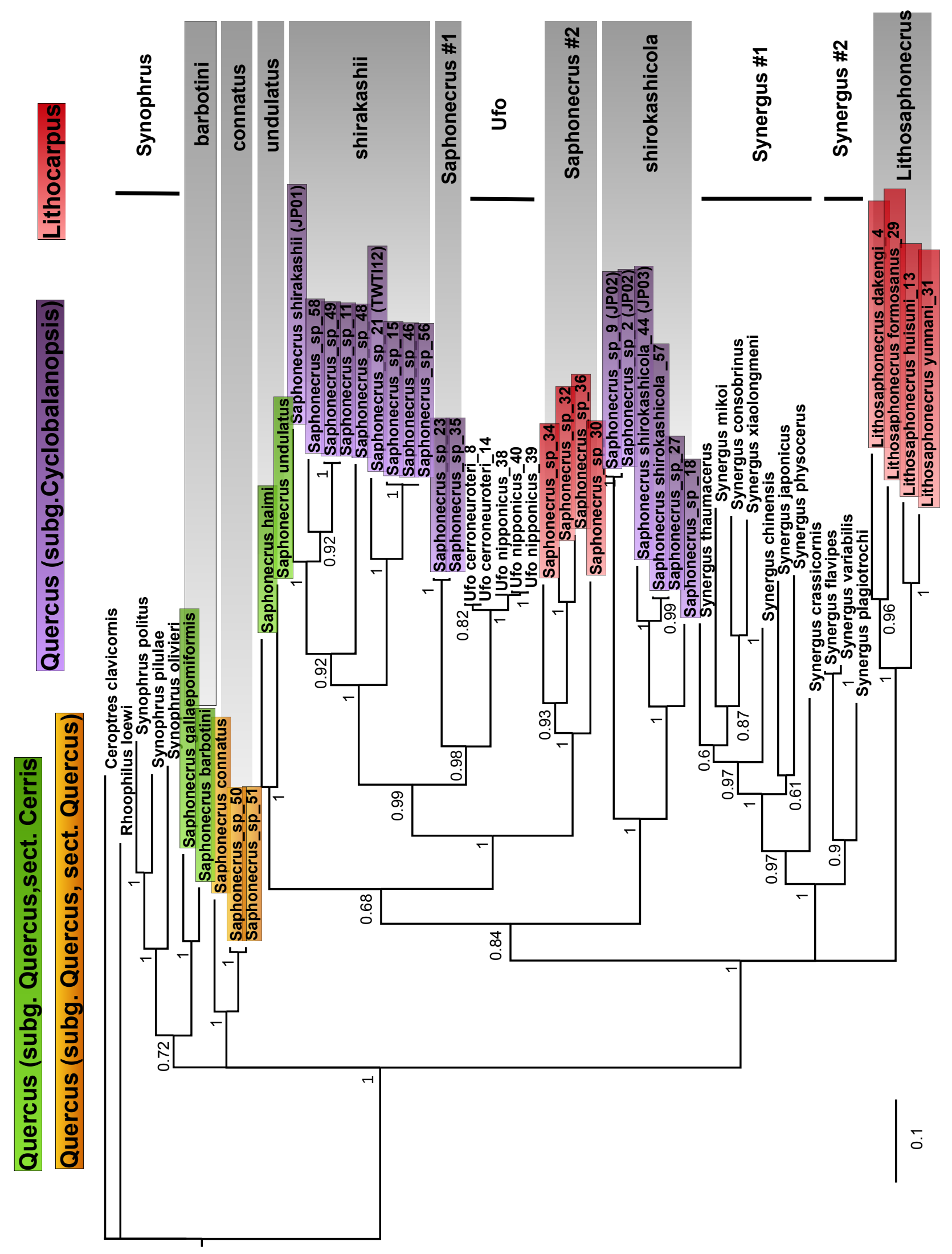

31. ábra: A vizsgált Saphonecrus és Saphonecrus-közeli példányok gazdanövény kapcsolatai a 4.táblázat kategóriái alapján csoportosítva. Szürke háttérrel a dolgozatom tárgyát képező kládokat emeltem ki. 
tölgyszekcióhoz, annak is az Ilex alcsoportjához társultak. Bármelyik folyamat játszódott is le társítható: ezek az elemzésünkben is résztvevő, Japánból és Tajvanról ismert S. shirakashii amely a $Q$. (Cyclobalanospis) glauca-val és $Q$. (C.) globosa-val míg a szintén Japánban és Tajvanon élő $S$. shirokashicola az előző fajhoz hasonlóan a $Q$. (C.) glauca-hoz, $Q$. (C.) longinux-hoz és a $Q$. (C.) salicina-hoz asszociálódott (Melika és mtsi 2012). A klád mindkét tajvani faja (Saphonecrus sp. 23, Saphonecrus sp. 35) a Q. (C.) globosa-hoz kapcsolódott.

A szintén eddig leíratlan tajvani fajokat tartalmazó, a kládon belül bazálisabb helyzetü „Saphonecrus \#2” szubklád gazdanövény kapcsolatai több szempontból is érdekesek voltak. Mivel fajaik kizárólag a Lithocarpus nemzetségekhez társultak ezért esetükben szintén feltételezhettünk egy Quercus-Lithocarpus vagy egy, a többi szubklád kapcsolatai alapján valószínübbnek tünő Cyclobalanopsis-Lithocarpus irányú gazdaváltást. Mindkét esetben génuszok közti gazdaváltásról beszélhetünk amely igen figyelemreméltó annak tükrében, hogy milyen szoros evolúciós kapcsolatot feltételeznek a cinipid inquilinfajok és növény gazdáik között.

Végül pedig meg kell még említenünk a négy újonnan leírt Lithosaphonecrus fajt magában foglaló kládot amely szintén kizárólagosan a Lithocarpus fajokhoz társult. Az elemzésünkbe bevont Synergus fajok gazdanövény kapcsolatait is figyelembe véve (Pénzes és mtsi 2012) ezen a leszármazási vonalon szintén a Quercus génusz irányából a Lithocarpus génusz irányában viszonylag korán lejátszódott gazdanövény váltást feltételezhetünk. 


\section{Diszkusszió}

A Fagaceae családhoz kötődő cynipid gubacsdarazsak gubacsaiban fejlődő inquilin cynipida fajokat (Cynipidae: Synergini) korábban 6 génuszra osztották fel (Ceroptres, Saphonecrus, Synergus, Synophrus, Ufo és Agastoroxenia). A korábbi molekuláris elemzések a Synerguskomplex (Saphonecrus, Synergus, Synophrus) monofiletikus eredetét támogatták és a Ceroptres génusztól határozottan elkülönítették (Ács és mtsi 2010; Melika és mtsi 2005, 2012; Pénzes és mtsi 2009). A Synergus-komplex tölgyfajokhoz asszociálódott Nyugat-Palearktikus inquilin fajainak - és különösképpen a Saphonecrus fajoknak - már régóta ellentmondásosnak tartják a filogenetikai kapcsolataikról felállított elméleteket (Ács és mtsi 2010). A kezdetben csupán életmódjuk alapján elkülönített 3 Saphonecrus csoportot (Pujade- Villar és Nieves-Aldrey 1990) a dolgozatomban bemutatott eredmények alapján megerősítettük.

Morfológiai és molekuláris vizsgálatunk alapján a Saphonecrus és Saphonecrus-közeli fajok három fő leszármazási vonalat alkotnak. Az első leszármazási vonal esetében igazolni tudtuk azt a korábbi elemzésekben felállított hipotézist, hogy a Saphonecrus gallaepomiformis és S. barbotini az összes ismert Synophrus fajjal közösen képez egy monofiletikus csoportot (Pénzes és mtsai 2009, Ács és mtsai 2010). A két Saphonecrus fajon egyes, a Synophrus és Saphonecrus génuszokra specifikus morfológiai karakterállapotok keverten fordulnak elő. Ezért úgy gondoljuk, hogy a csoporton belül ezeket a fajokat a fent említett morfológiai tulajdonságaik, valamint életmódjuk és elterjedésük miatt egy újonnan felállított génuszba át kellene sorolni.

A második leszármazási vonalat a „connatus” csoport alkotja, amely a Saphonecrus connatus mellett a Kelet-Palearktikus elterjedésü Callirhytis hakonensis gubacsdarázs fajhoz asszociálódott Saphonecrus példányokat is tartalmazott, ami alátámasztja a csoport korábban feltételezett Transz-Palearktikus elterjedését (Sakagami 1949, Abe és mtsi 2007). Morfológiai sajátosságaik és molekuláris vizsgálataink eredményei alapján ebben az esetben a Saphonecrus fajkomplexnek egy olyan korán elkülönülő taxonómiai egységéről - esetleg génuszáról - lehet szó amely határozottan elkülönül a Nyugat-Palearktikus Saphonecrus fajok „,barbotini” kládjától.

Az elemzésünkbe bevont összes további Saphonecrus fajt magába foglaló harmadik leszármazási vonalba tartoznak az „undulatus” kládba sorolt S. haimi és S. undulatus fajok melyeket gazdanövény kapcsolataik alapján akár a Kelet-Palearktikumból kiinduló, különböző tölgy leszármazási vonalakhoz kötődő inquilin radiáció nyugati képviselőinek is tekinthetünk. A teljes klád hordozza az „undulatus” csoport morfológiai sajátosságait. A leszármazási vonalat számos további ágra tudtuk bontani, ezek egyike Lithosaphonecrus génusz, míg egy másik a 
Synergus génusz fajait tartalmazta. A Fagaceae család Lithocarpus nemzetségének mintegy 334 faja őshonos Kelet- és Délkelet-Ázsiában (Govaerts \& Frodin 1998; Manos és mtsi 2001). Tajvan szigetéről jelenleg csak két gubacsdarázs fajról (Cycloneuroterus formosanus Tang \& Melika és Dryocosmus testisimilis Tang \& Melika) tudjuk, hogy képesek Lithocarpus fajokon gubacsot indukálni (Melika és mtsi 2011; Tang és mtsi 2011a). Vizsgálatunk előtt egyetlen olyan inquilin darázsfajról sem számoltak be amely a Lithocarpus nemzetség cynipid gubacsdarazsainak gubacsaiban fejlödött volna. A munkámban bemutatott Lithosaphonecrus génusz négy faját tehát a Lithocarpus génuszhoz társuló, jelenleg még ismeretlen gubacsdarázs gazdával rendelkező első ismert társbérlő fajoknak tekinthetjük. Ugyanezen a leszármazási vonalon belül előzetes filogenetikai és morfológiai vizsgálataink eredményeként a KeletPalearktikus Saphonecrus egyedeknek egy másik elkülönülő csoportját is azonosítani tudtuk, melynek tagjai szintén a Lithocarpus fajokhoz asszociálódtak. Ezen fajok azonban morfológiájuk és vizsgált génszekvenciáik (COI és 28S D2) alapján egyértelmüen elkülönülnek az általunk leírt Lithosaphonecrus génusztól.

A Saphonecrus fajok fö leszármazási vonalai, valamint a további Saphonecrus leszármazási egységek olyan specifikusan rájuk jellemző morfológiai karakterállapotokkal rendelkeznek melyek alapján könnyen megkülönböztethető önálló morfológiai egységeket génuszokat - képeztek. Egyértelmü, hogy a Saphonecrus génusz jelenlegi határai tovább nem tarthatóak fenn, azokat meg kell változtatni és új monofiletikus génuszokat kell felállítani. Az új génuszok felállítása miatt természetesen a nevezéktanban is változások várhatóak, illetve a Kelet-Palaearktikus és Orientális Régió (Tajvan) új fajainak leírásával párhuzamosan az új génuszok részletes morfológiai jellemzésére is hamarosan sor kerülhet.

A gazda specifikus differenciáció a fajképződés egyik fontos tényezője lehet a növénynövényevő és a gazda-parazita rendszerekben (Abrahamson és mtsi 2001, Baer és mtsi 2004; Forbes és mtsi, 2009). A gubacs különböző jellemzői hatással lehetnek az inquilin darázs peterakási sikerére. Ilyenek lehetnek például a gubacs külső parenchimájának jellegzetességei (pl. ragacsos vagy pihés felszín), lignifikáció mértéke, vagy a gubacs falvastagsága. Ezekről már ismert, hogy a parazitoidok peterakási sikerét befolyásolhatják (Bailey és mtsi 2009). A gubacs ezen tulajdonságait a gubacsdarázs kontrollálja (kivétel a Synophrus génusz fajai), és gyakran fajspecifikusak, ami alapján nem zárható ki olyan inquilin rasszok megjelenése, melyek hasonló típusú gubacsokat részesítenek előnyben. A munkánkban elemzett eddig még leíratlan KeletPalearktikus Saphonecrus és Lithosaphonecrus példányok döntő többségének gubacsdarázs gazdafaja jelenleg még ismeretlen. Ezért vizsgálatunkban filogenetikai kapcsolataik alapján kvalitatíve elemeztük az inquilinek gazdagubacs asszociációit. Eredményeink alapján a gubacsok 
növényen elfoglalt helyzetében, a levélgubacsoknak a leveleken elfoglalt helyzetében és a gubacsok felszíni mintázatában tapasztalt eltérések nem cáfolták a morfológiai- és molekuláris vizsgálatokon alapuló rokonsági viszonyokat, illetve az egyes leszármazási vonalakon belül felállított alcsoportok határait. Eredményeinkből a feltételezhetően szubjektív mintavétel miatt, illetve statisztikai tesztelés nélkül általános következtetéseket azonban nem vonhatunk le. Ennek ellenére a közölt adatok hasznos kiegészítői lehetnek a területet érintő további kutatásoknak.

Elsősorban a Nyugat-Palearktikus tölgy gubacsdarazsakkal végzett legfrissebb filogenetikai kutatások jelentős különbségeket találtak a különböző tölgyszekciókhoz kötődő gubacsdarázs közösségek között (Cook és mtsi 2002, Ács és mtsi 2007, Stone és mtsi 2009) aminek magyarázata a köztük fennálló konzervatív kapcsolat lehet. A Synergus-komplex esetében hasonlóan konzervatív evolúciós kapcsolatokat vártunk (Ács és mtsi 2010). Vizsgálatunk azonban az inquilin fajok és a hozzájuk köthető gazdanövények független radiációját sugallja. Erre a két legszembetünőbb példa a Lithocarpus nemzetséghez kötődő már említett két leszármazási vonal. A Fagaceae családon belül a Quercus és a Lithocarpus génuszok korai szétválása (Oh és Manos 2008) nem tükröződött a vizsgált inquilin fajok törzsfejlődésében. Továbbá úgy tünik, hogy a Quercus nemzetség Cerris szekciójára specifikus Kelet-Palearktikus Ufo génusz és a Nyugat-Palearktus fajokat magában foglaló „undulatus” leszármazási egység a Cyclobalanopsis szubgénuszhoz asszociálódott Saphonecrus vonalakhoz kapcsolódik. További kutatásokra van szükség annak érdekében, hogy pontosan felderíthessük a cynipid inquilin leszármazási vonalakon lejátszódott gazdanövény váltásokat. 


\section{Köszönetnyilvánítás}

Ezúton szeretném megköszönni témavezetöimnek, Dr. Melika Georgenak és Dr. Pénzes Zsoltnak, hogy önzetlen segítségükkel munkámat lehetővé tették. Továbbá köszönettel tartozom az SZBK Genetikai Intézetében működő Molekuláris Biodiverzitás Csoport minden volt munkatárásnak, főként Dr. Somogyi Kálmánnak, Szabó Krisztiánnak, Dr. Sipos Botondnak, Dr. Bihari Péternek és Dr. Fülöp Dávidnak a labormunkában nyújtott segítségükért és támogatásukért.

Köszönettel tartozom a NÉBIH-NTAI Növény-egészségügyi és Molekekuláris Biológiai Laboratóriumában dolgozó munkatársaimnak doktori munkám támogatásáért, önzetlen segítségükért és azért a baráti légkörért, amiben öröm volt dolgozni.

Végül, de nem utolsó sorban szeretném megköszönni családom kitartó támogatását, ami lehetővé tette egyetemi és posztgraduális tanulmányaimat, és azt, hogy mindvégig hagyták, hogy a saját fejem után menjek. 


\section{Irodalomjegyzék}

Abe, Y. 1990: Life cycles of two species of the Synergus japonicus complex (Hymenoptera: Cynipidae). - Akitu, 120, 1-7.

Abe, Y. 1997: Discovery of the genus Ceroptres (Hymenoptera: Cynipide) in Japan and Korea. Applied Entomology and Zoology, 32(1), 253-255.

Abe, Y. 1998: Palaearctic occurrence of the genus Synophromorpha (Hymenoptera: Cynipidae) confirmed on the basis of a new species from Japan. - Entomologica scandinavica, 29, 25-28.

Abe, Y., Ide, T. and Wachi, N. 2011: Discovery of a new gall-inducing species in the inquiline tribe Synergini (Hymenoptera: Cynipidae): inconsistent implications from biology and morphology. - Annals of the Entomological Society of America, 104(2), 115-120.

Abe, Y., Melika, G. and Stone, G.N. 2007: The diversity and phylogeography of cynipid gallwasps (Hymenoptera: Cynipidae) of the Oriental and Eastern Palaearctic Regions, and their associated communities. - Oriental Insects, 41, 169-212.

Abrahamson, W.G., Eubanks, M.D., Blair, C.P., Whipple, A.V. 2001: Gall flies, inquilines and goldenrods: a model for host-race formation and sympatric speciation. American Zoologist 41: 928-938.

Ács, Z., Challis, R., Bihari, P., Blaxter, M., Hayward, A., Melika, G., Csóka, Gy., Pénzes, Zs., Pujade-Villar, J., Nieves-Aldrey, J.L., Schönrogge, K. and Stone, G.N. 2010: Phylogeny and DNA barcoding of inquiline oak gallwasps (Hymenoptera: Cynipidae) of the Western Palaearctic. - Molecular Phylogenetics and Evolution, 55, 210-225.

doi:10.1016/j.ympev.2009.12.004.

Ács, Z., Melika, G., Pénzes, Z., Pujade-Villar, J. and Stone. G.N. 2007: The phylogenetic relationships between Dryocosmus, Chilaspis and allied genera of oak gallwasps (Hymenoptera, Cynipidae: Cynipini). - Systematic Entomology, 32, 70-80.

Ashmead, W.H. 1896a: Descriptions of new cynipidous gall-wasps in the United States National Museum. - Proceedings of the U.S. National Museum, 19, 113-136.

Ashmead, W.H. 1903: Classification of the gall-wasps and the parasitic cynipoids, or the superfamily Cynipoidea. III. - Psyche (Cambridge), 10, 140-155.

Askew, R.R. 1984: The Biology of gall wasps. Pp. 223-271 in: Ananthakrishnan, T.N. (ed.) Biology of gall insects. Edward Arnold, London. 
Baer, C.F., Tripp, D.W., Bjorksten, T.A., Antolin, M.F. 2004: Molecular phylogeography of a parasitoid wasp (Diaeretiella rapae): no evidence of host-associated lineages. Ecology

13: 1859-1869.

Bailey, R., Schönrogge, K., Cook, J.M., Melika, G., Csóka, G., Thúroczy, C., Stone, G.N. 2009: Host niches and defensive extended phenotypes structure parasitoid wasp communities. PLoS Biology 7: e1000179.

Belizin, V.I. 1973: New cynipids (Hymenoptera, Cynipoidea) from the USSR and neighbouring countries. - Revue d'Entomologie de l'URSS, 52(1), 29-38.

Bonfield, J.K., Smith, K.F. \& Staden, R. 1995: A new DNA sequence assembly program. Nucleic Acids Research, 23, 4992-4999.

Bozsó M., Tang C.-T., Pénzes Z., Yang M.-M., Bihari P., Pujade-Villar J., Schwéger S. and Melika G. 2013: A new genus of cynipid inquiline, Lithosaphonecrus Tang, Melika \& Bozsó (Hymenoptera: Cynipidae: Synergini), with description of four new species from Taiwan and China. Insect Systematics \& Evolution doi 10.1163/1876312X-45032116.

Brooks, S.E. and Shorthouse, J.D. 1998: Developmental morphology of stem galls of Diplolepis nodulosa (Hymenoptera: Cynipidae) and those modified by the inquilinePericlistus pirata (Hymenoptera: Cynipidae) on Rosa blanda (Rosaceae). - Canadian Journal of Botany, 76, $365-381$.

Buffington, M. and Liljeblad, J. 2008: The Description of Euceroptrinae, a New Subfamily of Figitidae (Hymenoptera), including a Revision of Euceroptres Ashmead, 1896 and the Description of a New Species. - Journal of Hymenoptera Research, 17(1), 44-56.

Burks, B.D. 1979: Cynipoidea. Pp. 1045-1107 in K.V. Krombein, P.D. Hurd, Jr., D.R. Smith, and B.D. Burks (eds). Catalog of Hymenoptera in North America north of Mexico, vol. 1. Smithsonian Institution Press, Washington, D.C.

Camus, A. 1936-1954: Les chenes monographie du genre Quercus (et Lithocarpus). Encyclopédie economique de sylviculture, vols. 6-8. Academie des Sciences, Paris.

Cannon, C.H. and Manos, P.S. 2003: Phylogeography of Southeast Asian stone oaks (Lithocarpus). - Journal of Biogeography, 30, 211-226.

Caterino, M.S., Cho, S., Sperling, F.A.H. 2000: The current state of insect molecular systematics: A thriving Tower of Babel. Annual Review of Entomology. 45: 1-54. 
Cook, J.M., Rokas, A. Pagel, M. and Stone, G.N. 2002: Evolutionary shifts between host oak species and host plant organs in Andricus gallwasps. - Evolution, 56, 1821-1830.

Csóka, G., Stone, G.N. and Melika, G. 2005: Biology, Ecology and Evolution of gall-inducing Cynipidae. Pp. 569-636 in: Biology, ecology and evolution of gall-inducing arthropods (eds. Raman, A., C.W. Schaefer \& T.M. Withers). Science Publishers, Inc. Enfield, New Hampshire, USA.

Dalla Torre, K.W. and Kieffer, J.J. 1910: Cynipidae. Das Tierreich, 24. Berlin, Friedlander \& Sohn, 35, 1-891.

Dettmer, H.S.J. 1924: Neue Cynipidae aus Niederlanden I. - Natuurhistorisch Maandblad Maastricht, 13(9), 126-127.

Docters van Leuwen-Reijnvaan J. and Docters van Leuwen, W.M. 1926: The zoocecidia of the Netherlands East Indies. Drukkerij de Unie, Jakarta.

Duffett, G.H. 1968: Some new interrelationships of Hymenoptera over-wintering within the galls of Andricus kollari (Hartig). - The Entomologist's Monthly Magazine, 105, 1259-1261

Edgar, R.C. 2004: MUSCLE: multiple sequence alignment with high accuracy and high throughput. - Nucleic Acids Research, 32, 1792-1797.

Espírito-Santo, M.M. \& Fernandes, G.F. 2007: How many species of gall-inducing insects are there on earth, and where are they? Annals of the Entomological Society of America., 100: 95-99 Evans, D. 1965: The life history and immature stages of Synergus pacificus McCracken and Egbert (Hymenoptera: Cynipidae). - The Canadian Entomologist, 97, 185-188.

Fergusson, N.D.M. 1995: The cynipoid families. Pp. 247-265 in: Hanson, P.E. and Gauld, I.D. (eds.) The Hymenoptera of Costa Rica. Oxford University Press. Oxford, New York, Tokyo.

Flora of Taiwan. 1996: Volume 2. Angiospermes. Editorial Committee of the Flora of Taiwan, Second Edition. Taipei, Taiwan, ROC.

Folmer, O., Black, M.B., Hoch, W., Lutz, R.A. \& Vrijenhock, R.C. 1994: DNA primers for amplification of mitochondrial cytochrome c oxidase subunit I from metazoan invertebrates. Molecular Marine Biology and Biotechnology, 3, 294-299.

Forbes, A.A., Powell, T.H.Q, Stelinski, L.L., Smith, J.J., Feder, J.L. 2009: Sequential sympatric speciation across trophic levels. Science 323: 776-779.

Fujii, T., Matsuo, K., Abe, Y., Yukawa, J., Tokuda, M. 2014: An endoparasitoid avoids 
hyperparasitism by manipulating immobile host herbivore to modify plant morphology. PLoS ONE 9: e102508.

Govaerts, R. and Frodin, D.G. 1998: World Checklist and Bibliography of Fagales. - Kew: Royal Botanic Gardens, Kew. 408 pp.

Hancock, J.M., Tautz, D. \& Dover, G.A. 1988: Evolution of the secondary structures and compensatory mutations of the ribosomal RNAs of Drosophila melanogaster. Molecular Biology and Evolution, 5, 393-414.

Harris, R. 1979: A glossary of surface sculpturing. State of California, Department of Food and Agriculture, Occasional Papers in Entomology, 28, 1-31.

Hartig, T. 1840: Über die Familie der Gallwespen. - Zeitschrift für die Entomologie, herausgegeben von Ernst Friedrich Germar, 2, 176-209.

Hartig, T. 1843: Zweiter nachtrag zur naturgeschichte der gall-wespen. - Zeitschrift für die Entomologie, 4, 395-422.

Kumashiro, S., Matsukura, K., Kawaura, K., Matsumura, M., Ogihara, Y., Tokuda, M. 2011: Effect of barley chromosome addition on the susceptibility of wheat to feeding by a gallinducing leafhopper. Naturwissenschaften 98: 983-987.

Liljeblad, J. 2002: Phylogeny and evolution of gall wasps (Hymenoptera: Cynipidae). Department of Zoology, Stockholm University, 176 pp. Doctoral thesis.

Liljeblad, J., Nieves-Aldrey, J.L., Neser, S. and Melika, G. 2011: Adding another piece to the cynipoid puzzle: the description of a new tribe, genus and species of gall wasp (Hymenoptera: Cynipidae) endemic to The Republic of South Africa. - Zootaxa, 2806, 35-52.

Liljeblad, J. and Ronquist, F. 1998: A phylogenetic analysis of higher-level gall wasp relationships (Hymenoptera: Cynipidae). - Systematic Entomology, 23, 229-252.

Liljeblad, J., Ronquist, F., Nieves-Aldrey, J.L., Fontal-Cazalla, F., Ros-Farré, P., Gaitros, D. and Pujade-Villar, J. 2008: A fully web-illustrated morphological phylogenetic study of relationships among oak gall wasps and their closest relatives (Hymenoptera: Cynipidae). Zootaxa, 1796, 1-73.

Linkuo, F. and Tao, H. (eds.) 1998: Higher plants of China. Volume 4. Qingdao Publishing House, China.

Liu, Zh., Yang, X.-H., Zhu, D.-H. and He, Y.-Y. 2012: A New Species of Saphonecrus 
(Hymenoptera, Cynipoidea) Associated with Plant Galls on Castanopsis (Fagaceae) in China. Annals of the Entomological Society of America, 105(4), 555-561.

Manos, P.S., Doyle, J.J. and Nixon, K.C. 1999: Phylogeny biogeography and processes of molecular differentiation in Quercus subgenus Quercus (Fagaceae). - Molecular Phylogenetics and Evolution, 12, 333-349.

Manos, P.S. and Stanford, A.M. 2001: The historical biogeography of Fagaceae: tracking the tertiary history of temperate and subtropical forests of the Northern Hemisphere. - International Journal of Plant Sciences, 162, 577-593, Supplement 6.

Manos, P.S., Zhou, Z. and Cannon, C.H. 2001: Systematics of Fagaceae: phylogenetic tests of reproductive trait evolution. - International Journal of Plant Science, 162, 1361-1379.

Manos, P.S., Cannon, C.H. and Oh, S.-H. 2008: Phylogenetic relationships and taxonomic status of the paleoendemic Fagaceae of western North America: recognition of a new genus, Notholithocarpus. - Madroño, 55(3), 183-192.

Mayr, G. 1872: Die Einmiethler der mitteleuropäischen Eichengallen. - Verhandlungen der Zoologisch-Botanischen Geselschaft in Wien, 22, 669-726.

Mayr, G. 1881: Die Genera der gallenbewohnenden Cynipiden. -20. Jahresb. Rossauer Communal-Oberealschule, Wien, Bezirke d. 1(20), 1-38.

Melika, G. 2006: Gall Wasps of Ukraine. Cynipidae. Vestnik zoologii, supplement 21(1-2), 1$300,301-644$.

Melika, G. and Buss, E.A. 2002: Description of the sexual generation of Callirhytis quercuscornigera and a new inquiline (Hymenoptera: Cynipidae). - Florida Entomologist, 85(4), $625-631$.

Melika, G., Ros-Farré, P., Pénzes, Zs., Ács, Z. and Pujade-Villar, J. (2005): Ufo abei Melika et Pujade-Villar (Hymenoptera: Cynipidae: Synergini) new genus and new species from Japan. Acta Zoologica Academiae Scientiarum Hungaricae, 51(4), 313-327.

Melika, G., Choi, J.Y., Pujade-Villar, J., Pénzes, Zs. and Fülöp, D. 2007: A new species of inquiline cynipid of the genus Ufo Melika \& Pujade-Villar, 2005 from Korea (Hymenoptera: Cynipidae: Synergini). - Journal of Asian-Pacific Entomology, 10(3), 197-200.

Melika, G., Pujade-Villar, J., Abe, Y., Tang, C.-T., Nicholls, J., Wachi, N., Ide T., Yang, M.M., Pénzes, Z., Csóka, G. and Stone, G.N. 2010: Palaearctic oak gallwasps galling oaks 
(Quercus) in the section Cerris: re-appraisal of generic limits, with descriptions of new genera and species (Hymenoptera: Cynipidae: Cynipini). - Zootaxa, 2470, 1-79.

Melika, G., Tang, C.-T., Nicholls, J., Yang, M.-M. and Stone, G.N. 2011: Four new species of Dryocosmus gallwasps from Taiwan (Hymenoptera: Cynipidae, Cynipini). - ISRN Zoology, Volume 2011, Article ID 725180, 17 pages; doi:10.5402/2011/725180.

Melika, G., Tang, C.-T., Yang, M.-M., Bihari, P., Bozsó, M. and Pénzes, Zs. 2012: New species of cynipid inquilines of the genus Ufo Melika \& Pujade-Villar, 2005 (Hymenoptera: Cynipidae: Synergini). - Zootaxa, 3478, 143-163.

Melika, G., Tang, Chang-Ti, Sinclair, F., Yang, M.-M., Lohse, K., Hearn, J., Nicholls, J.A. \& Stone, G.N. 2013: A new genus of oak gallwasp, Cyclocynips Melika, Tang \& Sinclair (Hymenoptera: Cynipidae: Cynipini), with descriptions of two new species from Taiwan, Zootaxa 3630 (3), pp. 534-548

Negi, S.S. and Naithani, H.B. 1995: Oaks of India, Nepal and Bhutan. International Book Distributors, Dhera Dun, India.

Nicholls, J.A., Preuss, S., Hayward, A., Melika, G., Csoka, G., Nieves-Aldrey, J-L., Askew, R.R., Tavakoli, M., Schonrogge, K. \& Stone, G.N. 2010: Concordant phylogeography and cryptic speciation in two Western Palaearctic oak gall parasitoid species complexes. Molecular Ecology, 19, 592-609.

Nieves-Aldrey, J.L. 2001: Hymenoptera, Cynipidae. In: Ramos, M.A., Alba, J., Bellés, X., Gosálbez, J., Guerra, A., Macpherson, E., Martín, F., Serrano, J. and Templado, J. (eds.) Fauna Ibérica, vol. 16. Museo Nacional de Ciencias Naturales, CSIC, Madrid, 636 pp.

Nieves-Aldrey, J.L. 2005: Notes on the Neotropical species of Synergus (Hymenoptera, Cynipidae), with description of a new species from Colombia. - The Canadian Entomologist, $137,501-508$.

Nieves-Aldrey, J.L. and Medianero, E. 2010: Agastoroxenia panamensis, a new genus and species of inquiline oak gall wasps (Hymenoptera: Cynipidae: Synergini) of the Neotropics. Annals of the Entomological Society of America, 103, 492-499.

Nieves-Aldrey, J.L. and Medianero, E. 2011: Taxonomy of inquilines of oak gall wasps of Panama, with description of eight new species of Synergus Hartig (Hymenoptera, Cynipidae, Synergini). - Zootaxa, 2774, 1-47.

Nieves-Aldrey, J.L. and Pujade-Villar, J. 1986: Sobre las especies ibéricas de la Sección II 
(Mayr, 1872) del género Synergus Htg. con descripción de una especie nueva (Hym., Cynipidae, Cynipinae). - Eos, 62, 137-165.

Nieves-Aldrey, J.L., Vårdal, H. and Ronquist, F. 2005: Comparative morphology of terminalinstar larvae of Cynipoidea: phylogenetic implications. - Zoologica Scripta, 34(1), 15-36.

Nixon, K.C. 1985: A biosystematic study of Quercus section Virentes (the live oaks) with phylogenetic analyses of Fagales, Fagaceae and Quercus. - Ph. D. dissertation, University of Texas, Austin.

Nixon, K.C. 1993: Infrageneric classification of Quercus (Fagaceae) and typification of sectional names. - Annals of Science Forest, 50 (Supplement), 25S-34S.

Nordlander, G. 1984: What do we know about parasitic cynipoids (Hymenoptera). -

Entomologisk Tidskrift, 105, 36-40.

Nylander, J.A.A. 2004a: Bayesian Phylogenetics and the evolution of gall wasps. Ph.D. Thesis. Acta Universitatis Upsaliensis. Uppsala.

Nylander, J.A.A. 2004b.: MrModeltest v2. Program distributed by the author. Evolutionary Biology Centre, Uppsala University.

Nylander, J.A.A., Ronquist, F., Huelsenbeck, J.P. and Nieves-Aldrey, J.L. 2004: Bayesian phylogenetic analysis of combined data.Systematics Biology 53, 47-67.

Ôtake, A., Shiga, M. and Moriya, S. 1982: A study on parasitism of the chestnut gall wasp, Dryocosmus kuriphilus Yasumatsu (Hymenoptera: Cynipidae) by parasitoids indigenous to Japan. - Bulletin of the Fruit Tree Research Station, A9, 177-192.

Oh, S.-H. and Manos, P.S. 2008: Molecular phylogenetics and cupule evolution in Fagaceae as inferred from nuclear CRABS CLAW sequences. - Taxon, 57(2), 434-451.

Ohwi, J. 1961: Flora of Japan. Shibundo, Tokyo, 1383 pp. (in Japanese).

Pénzes, Zs., Melika, G., Bozsóki, Z., Bihari, P., Mikó, I., Tavakoli, M., Pujade-Villar, J., Fehér, B., Fülöp, D., Szabó, K., Bozsó, M., Sipos, B., Somogy, K. and Stone, G.N. 2009: Systematic re-appraisal of the gall-usurping wasp genus Synophrus Hartig, 1843 (Hymenoptera: Cynipidae: Synergini). - Systematic Entomology, 34, 688-711. doi: 10.1111/j.13653113.2009.00482.x

Pénzes, Zs., Tang, Chang-Ti, Bihari, P., Bozsó, M., Schwéger, Sz. \& Melika, G. 2012: Oak associated inquilines (Hymenoptera, Cynipidae, Synergini). Tiscia Monograph Series 11, Szeged, 1-76 
Pujade-Villar, J. 1992: Sobre Synergus ilicinus (Barbotin, 1972) n. comb. y otras especies de Synergus Htg. en el Nordeste de la Peninsula Ibérica (Hym., Cynipidae, Synergini). - Boletín de la Asociación española de Entomología, 16, 129-148.

Pujade-Villar, J., Melika, G., Ros-Farré, P. \& Ács, Z. and Csóka, G. 2003: Cynipid inquiline wasps of Hungary, with taxonomic notes on the Western Palaearctic fauna (Hymenoptera: Cynipidae, Cynipinae, Synergini). - Folia Entomologica Hungarica, 64, 121-170.

Pujade-Villar, J. and Melika, G. 2005: Synergus castanopsidis (Beutenmüller, 1918) and Synergus mexicanus Gillette, 1896, two conflictive cynipid inquiline species from America (Hymenoptera, Cynipidae: Synergini). Boletin Sociedad Entomológica Aragonesa 37(2005), 215-218.

Pujade-Villar, J. and Nieves-Aldrey, J.L. 1990: Revisión de las especies europeas del género Saphonecrus Dalla Torre \& Kieffer, 1910 (Hymenoptera: Cynipidae: Cynipinae). - Butlletí de 1' Institució Catalana d'História Natural, 58(8), 45-55.

Raman, A., Beiderbeck, R., Herth, W. 2009: Early subcellular responses of susceptible and resistant Vitis taxa to feeding by grape Phylloxera Daktulosphaira vitifoliae. Bot Helv., 119: 3139

Rambaut, A., Drummond, A.J. 2007: Tracer v1.4. Available from http://beast.bio.ed.ac.uk/Tracer

Ritchie, A.J. 1984: A review of the higher classification of the inquiline gall wasps (Hymenoptera: Cynipidae) and a revision of the Nearctic species of Periclistus Förster. Ph. D. diss. Carleton University, Ottawa.

Ritchie, A.J. and Shorthouse, J.D. 1987: Revision of the genus Synophromorpha Ashmead (Hymenoptera: Cynipidae). - The Canadian Entomologist 119, 215-230.

Rocha, S., Branco, M., Vilas Boas, L., Almeidal, M.H., Protasov, A and Mendel, Z. 2013:

Gall induction may benefit host plant: a case of a gall waspand eucalyptus tree. Tree Physiology 33, 388-397. doi:10.1093/treephys/tpt009

Rokas, A., Melika, G., Abe, Y., Nieves-Aldrey, J.-L., Cook, J.M. and Stone, G.N. 2003: Lifecycle closure, lineage sorting and hybridization revealed in a phylogenetic analysis of European oak gall wasps (Hymenoptera: Cynipidae: Cynipini) using mitochondrial sequence data. - Molecular Phylogenetics and Evolution, 26, 36-45.

Ronquist, F. 1994: Evolution of parasitism among closely related species: Phylogenetic 
relationships and the origin of inquilinism in gall wasps (Hymenoptera, Cynipidae). - Evolution, $48,241-266$

Ronquist, F. 1995: Phylogeny and early evolution of Cynipoidea (Hymenoptera). - Systematic Entomology, 20, 309-335.

Ronquist, F. 1999: Phylogeny, classification and evolution of the Cynipoidea. - Zoologica Scripta, 28, 139-164.

Ronquist, F. and Liljeblad, J. 2001: Evolution of the gall wasp-host-plant association. Evolution, 55, 2503-2522.

Ronquist, F. and Nieves-Aldrey, J.L. 2001: A new subfamily of Figitidae (Hymenoptera, Cynipoidea). - Zoological Journal of the Linnean Society, 133, 483-494.

Ronquist, F., Nordlander, G. 1989: Skeletal morphology of an archaic cynipoid, Ibalia rufipes (Hymenoptera, Ibaliidae). Entomologica Scandinavica Supplements 33: 1-60.

Ronquist, F., Teslenko, M., van der Mark, P.,Ayres, D.L., Darling, A., Höhna, S., Larget,B., Liu, L., Suchard, M.A. and Huelsenbeck,J.P. 2012: MrBayes 3.2: Efficient bayesian phylogenetic inference and model choice across a large model space. Systematic Biology 61, $539-42$.

Ross-Farré, P. and Pujade-Villar, J. 2007: Plectocynipinae, a new subfamily of Figitidae and description of a new Neotropical genus of Thrasorinae (Hymenoptera: Cynipoidea). - Zootaxa, $1583,1-13$

Sadeghi, S.E., Melika, G., Pujade-Villar, J., Pénzes, Zs., Ács, Z., Bechtold, M., Assareh, M.H., Tavakoli, M., Yarmand, H., Askary, H., Stone, G.N., Azizkhani, E., Zargaran, M.R., Aligolizade, D., Barimani, H. and Dordaei, A.A. 2006: Oak cynipid gallinquilines of Iran (Hym.: Cynipidae: Synergini), with description of new species. - Journal of the Entomological Society of Iran, 25(2), 15-50.

Sakagami, S. 1949: Notes on Saphonecrus connatus (Hartig) (Hym., Cynipidae). - Matsumushi, 3, 112-115 (in Japanese).

Sanver, D. and Hawkins, B.A. 2000: Galls as habitats: the inquiline communities of insect galls. - Basic and Applied Ecology, 1, 3-11.

Schönrogge, K. and Crawley, M.J. 2000: Quantitative webs as a means of assessing the impact of alien insects. - Journal of Animal Ecology, 69, 841-868. 
Schönrogge, K. Stone, G.N. and Crawley, M. 1996: Alien herbivores and native parasitoids: rapid developments and structure of the parasitoid and inquiline complex in an invading gall wasp Andricus quercuscalicis (Hymenoptera, Cynipidae). - Ecological Entomology, 21, 71-80.

Shorthouse, J.D. 1973: The insect community associated with rose galls of Diplolepis polita (Cynipidae, Hymenoptera). - Quaestiones Entomologicae, 9, 55-98.

Shorthouse, J.D. 1980: Modification of galls of Diplolepis polita by the inquiline Periclistus pirata. - Bulletin de la Societe Botanique de France Actualites Botaniques, 127, 79-84.

Stone, G.N. and Cook, J.M. 1998: The structure of cynipid oak galls: patterns in the evolution of an extended phenotype. - Proceedings of the Royal Society, London B, 265, 979-988.

Stone, G.N., Hernandez-Lopez, A., Nicholls, J.A., di Pierro, E., Pujade-Villar, J, Melika, G. and Cook, J.M. 2009: Extreme host plant conservatism during at least 20 million years of host plant pursuit by oak gallwasps. - Evolution, 63, 854-869.

Stone, G.N. and Schönrogge, K. 2003: The adaptive significance of insect gall morphology. Trends in Ecology and Evolution, 18, 512-522.

Stone, G.N., Schönrogge, K., Atkinson, R.J., Bellido, D. and Pujade-Villar, J. 2002: The population biology of oak gall wasps (Hymenoptera: Cynipidae). - Annual Review of Entomology, 47, 633-668.

Tamura, K., Peterson. D., Peterson, N., Stecher, G., Nei, M., \& Kumar, S. 2011: MEGA5: Molecular Evolutionary Genetics Analysis using maximum likelihood, evolutionary distance, and maximum parsimony methods. Molecular Biology and Evolution, 28, 2731-2739.

Tang, C-T., Melika, G., Yang, M.-M., Nicholls, J. and Stone, G.N. 2011a: New species of oak gallwasps from Taiwan (Hymenoptera: Cynipidae: Cynipini). - Zootaxa, 2865, 37-52.

Tang, C.-T., Melika, G., Nicholls, J., Yang, M.-M. and Stone, G.N. 2011b: A new genus of oak gallwasps, Cycloneuroterus Melika \& Tang, with the description of five new species from Taiwan (Hymenoptera: Cynipidae: Cynipini). - Zootaxa, 3008, 33-62.

Thorne, R.F. 1993: Phytogeography. Pp.132-153 in: Flora of North America North of Mexico (ed. FNA Edit Committee). Vol.I: Introduction. Oxford University Press, Oxford.

Tokuda, M., Jikumaru, Y., Matsukura, K., Takebayashi, Y., Kumashiro, S., Matsumura, M., Kamiya, Y. 2013: Phytohormones related to host plant manipulation by a gall-inducing leafhopper. PLoS ONE 8: e62350. 
van Noort, S., Stone, G.N., Whitehead, V.B. and Nieves-Aldrey, J.L. 2007: Biology of Rhoophilus loewi (Hymenoptera: Cynipoidea: Cynipidae), with implications for the evolution of inquilinism in gall wasps. - Biological Journal of the Linnaean Society, 90, 153-172.

Wachi, N., Ide, T. and Abe, Y. 2011b: Taxonomic status of two species of Andricus (Hymenoptera: Cynipidae) described by Shinji $(1940,1941)$ as gall inducers on Cyclobalanopsis. - Annals of the Entomological Society of America, 104(4), 620-626.

Wang, Y.-P., Chen, X.-X., Pujade-Villar, J., Wu, H. and He, J.-H. 2010: The genus Saphonecrus Dalla Torre et Kieffer, 1910 (Hymenoptera: Cynipidae) in China, with descriptions of two new species. - Biologia (Section Zoology), 65(6), 1034-1039.

Wang, Y.-P., Liu, Zh. and Chen, X.-X. 2012: Eastern palaearctic cynipid inquilines - the genus Ceroptres Hartig, 1840 with descriptions of two new species (Hymenoptera: Cynipidae: Cynipinae). - Annals of the Entomological Society of America, 105(3), 377-385.

Washburn, J.O. and Cornell, H.V. 1981: Parasitoids, patches, and phenology: their possible role in the local extinction of a cynipid gall wasp population. - Ecology, 62, 1597-1607.

Weld, H.H. 1926: Field Notes on Gall-inhabiting Cynipid Wasps with descriptions of new species. - Proceedings of the U.S. National Museum, 68(10), 1-131.

Weld, L.H. 1952: Cynipoidea (Hym.) 1905-1950. - Ann Arbor, Michigan. (Privately printed). $351 \mathrm{pp}$.

White, J.M., Ager, T.A., Adam, D.P., Leopold, E.B., Liu, G., Jette, H. and Schweger, C.E. 1997: An 18 million year record of vegetation and climate change in northwestern Canada and Alaska: tectonic and global climatic correlates. - Plaeogeography, Palaeoclimatology and Palaeoecology, 130, 293-306.

Wiebes-Rijks, A.A. 1979: A character analysis of the species of Synergus Hartig, Section II (Mayr, 1872) (Hymenoptera, Cynipidae). - Zoologische Mededelingen, 53(28), 297-321.

Wiebes-Rijks, A.A. 1982: Early parasitism of oak-apple galls (Cynips quercusfolii L., Hymenoptera, Cynipidae). - Netherlands Journal of Zoology, 32, 112-116.

Zhou, Z.-K. 1992: Origin, phylogeny, and dispersal of Quercus from China. - Acta Botanica Yunnanica, 14, 227-236.

Zhou, Z.-K. 1993: The fossil history of Quercus. - Acta Botanica Yunnanica, 15, 21-33.

Zhou, Z., Wilkinson, H. and Zheng-Yi, W. 1995: Taxonomical and evolutionary implications 
of the leaf anatomy and architecture of Quercus L. subgenus Quercus from China. - Cathaya, 7, $1-34$.

Yamaguchi, H., Tanaka, H., Hasegawa, M., Tokuda, M., Asami, T., Suzuki, Y. 2012:

Phytohormones and willow gall induction by a gall-inducing sawfly. New Phytologist 196: 586595.

Yoder, M. J., Mikó, I., Seltmann, K. C., Bertone, M. A., Deans, A. R. 2010: A Gross Anatomy Ontology for Hymenoptera. PLoS ONE 5 (12): e15991. doi:10.1371/journal.pone.0015991 


\section{8. Összefoglaló}

Az ízeltlábúak között többször is kialakult a gubacsindukálás képessége az evolúció során. A gubacsképzők közül az egyik legnagyobb és egyben a legváltozatosabb csoport a gubacsdarazsak (Hymenoptera: Cynipidae) családja. A Cynipidae magába foglal egy fitofág tribust (Hymenoptera: Cynipidae: Synergini), melynek tagjai ugyan képesek előidézni más gubacsdarazsak gubacsain belül az őket tápláló szövetek kifejlődését, de az evolúció során elvesztették gubacsindukáló képességüket, lárvájuk más gubacsképző fajok mellett társbérlőként (inquilin) fejlődik (Brooks és Shorthouse 1998).

A tölgygubacsok egy jellegzetes, viszonylag zárt életközösséget rejtenek, amelyben a gubacsképző lárváján kívül társbérlők, parazitoidok és hiperparazitoidok is élhetnek. Ezek közül a legkevésbé kutatott és ismert trofikus szint a társbérlők szintje. Ennek egyik oka az lehet, hogy a Synergini fajok határozása nehéz feladat. A Synergini tribus hozzávetőleg 186 fajt számlál (kutatásaink során további 4, újonnan leírt Lithosaphonecrus fajjal bővült), melyből 48 a Nyugat-Palearktikumban is megtalálható. Számos filogenetikai és taxonómiai kérdés tisztázatlan a társbérlőkkel kapcsolatban, melyek megválaszolásához molekuláris filogenetikai elemzésre is szükséges lehet a morfológiai alapú vizsgálatok mellett.

Jelenleg a molekuláris filogenetikai bizonyítékok arra utalnak, hogy a Synergini törzs nem monofiletikus, hanem az Aylacinin belül egymástól függetlenül kialakult 3 leszármazási vonalra osztható (Nylander és mtsi 2004a, Melika 2006, van Noort és mtsi 2007): (1.) a rózsafélékhez kötődő Synophromorpha-Periclistus csoport, (2.) a tölgyhöz kötődő Ceroptres génusz és (3.) a Synergus-komplex, amely a szintén tölgyhöz kötődő Ufo, Synophrus, Saphonecrus és Synergus génuszokból, valamint az Afrikában Rhus fajokon élő Rhoophilus génuszból áll.

A fajok Synergus-komplexumán belül végzett legutóbbi filogenetikai elemzések támogatják a nagy fajszámú Synergus és a kisebb Synophrus génuszok monofiletikus jellegét míg a Saphonecrus génusz monofiletikusságát cáfolják (Pénzes és mtsi 2009, Ács és mtsi 2010). Ezeket az eredményeket támogatják azok a komplexumot érintő legújabb filogenetikai elemzések is amelyek dolgozatom tárgyát képezik.

Munkámban célul tüztem ki a Synergus génusz komplexen belül a Saphonecrus, Synergus, Synophrus, Ufo és „Saphonecrus-közeli” csoportok új rendszertanának felállítását, a csoport új génuszának (Lithosaphonecrus), a hozzá tartozó típus fajnak, illetve a génuszba sorolt négy új fajnak a leírását. Célom volt, hogy igazoljam a Saphonecrus génusz filogenetikai vizsgálatának szükségességét és kvalitatívan áttekintsem a Saphonecrus-hoz tartozó 
fajok/fajcsoportok trofikai - gazdaállat és gazdanövény - kapcsolatait.

Gubacsdarazsak esetén gyakran használt molekuláris markerek a magi 28S D2 régiójának, valamint a mitokondriális citokróm c-oxidáz I alegység (COI) génjének szekvenciái. Mi is ezeket a markereket választottuk, mivel ezekkel nyílt módunk eredményeinket másokéval összevetni. Az inquilin darázs fajok morfológiájának leírása során a korszerű, cynipidákkal foglalkozó tanulmányok (Melika 2006, Melika és mtsi 2010, Liljeblad és mtsai 2008) terminológiáját követtük. Az elülső szárny erezetének rövidítései esetében Ronquist és Nordlander (1989), a kutikula felületi mintázatával kapcsolatos terminológia esetében pedig Harris (1979) munkáját vettük figyelembe.

Molekuláris vizsgálatunk alapján a korábbi vizsgálatok eredményeit megerősítve a Saphonecrus és Saphonecrus-közeli fajok három fö leszármazási vonal között oszlanak meg. Az elsőbe a „Synophrus+barbotini” csoport fajai (a Synophrus fajok mellett a Saphonecrus barbotini és $S$. gallaepomiformis mediterrán fajok) tartoztak. Munkánk során igazolni tudtuk azt a korábbi elemzések során felállított hipotézist, hogy a Saphonecrus gallaepomiformis és $S$. barbotini az összes ismert Synophrus fajjal közösen képez egy monofiletikus csoportot (Pénzes és mtsai 2009, Ács és mtsai 2010). Véleményünk szerint azonban ezen a csoporton belül a két Saphonecrus fajt helyzete jobban értelmezhető lenne, ha egyes morfológiai tulajdonságaik, életmódjuk és elterjedésük miatt egy újonnan felállított génuszba sorolnánk át őket.

A második fö vonalat a „connatus” csoport alkotta, amely a Saphonecrus connatus mellet még Oroszországból és Japánból származó két Kelet-Palearktikus egyedeit is tartalmazza. A jelenlegi Saphonecrus génusz státuszának megítélése szempontjából alapvető jelentőségü típus fajának, a Saphonecrus connatus-nak a helyzete. Eredményeink alapján a „connatus” leszármazási vonal tehát a keleti elterjedésü Callirhytis hakonensis gubacsdarázs fajhoz kapcsolódó Kelet-Palearktikus inquilin példányokat is tartalmazott, ez pedig alátámasztja a csoport Transz-Palearktikus elterjedését (Sakagami 1949, Abe és mtsi 2007). A csoport tagjai a Quercus szubgénusz Quercus szekciójához asszociálódtak. Morfológiai sajátosságaik és molekuláris vizsgálataink egyértelmüen arra utalnak, hogy ebben az esetben a Saphonecrus fajkomplexnek egy olyan korán elkülönülő taxonómiai egységéről- esetleg génuszról - lehet szó amely határozottan elkülönül a „barbotini” vonaltól. Továbbá a Quercus szubgénusz Cerris szekciójához társuló $S$. haimi és $S$. undulatus fajok akár a Kelet-Palearktikumból kiinduló, különböző tölgy leszármazási vonalakhoz kötődő inquilin radiáció nyugati képviselőinek is tekinthetőek.

Az elemzésünkbe bevont összes többi Saphonecrus fajt magába foglaló harmadik fő leszármazási vonalat számos további ágra tudtuk bontani, ezek egyike Lithosaphonecrus, míg 
egy másik a Synergus génusz fajait tartalmazta. A Synegus génusz monofiletikus eredetét illetően továbbra is szem elött kell tartanunk, hogy elemzésünkben is csak a Palearktikus fajokat szerepeltettük, így a teljes fajkészletének monofiletikus eredetét továbbra is tesztelni kell. Megfigyelhető, hogy a Nearktikus Synergus fajok morfológiája számos esetben jelentősen eltér a Palearktikus fajokétól. Előzetes morfológiai és molekuláris eredmények a Nearktikus fajokon belül legalább három egymástól jól elkülöníthető csoportot valószínűsítenek melyek teljes körü filogenetikai elemzése várhatóan jelentősen megváltoztatja a Synergus génusz jelenlegi értelmezését.

A Fagaceae család Lithocarpus nemzetségének mintegy 334 faja öshonos Kelet- és Délkelet-Ázsiában (Govaerts \& Frodin 1998; Manos és mtsi 2001). Tajvan szigetéről jelenleg csak két gubacsdarázs fajról (Cycloneuroterus formosanus Tang \& Melika és Dryocosmus testisimilis Tang \& Melika) tudjuk, hogy képesek Lithocarpus fajokon gubacsot indukálni (Melika és mtsi 2011; Tang és mtsi 2011). Vizsgálatunk előtt egyetlen olyan inquilin darázsfajról sem számoltak be, amely a Lithocarpus nemzetség cynipid gubacsdarazsainak gubacsaiban fejlödött volna. A munkámban is leírt új Lithosaphonecrus génusz négy faját a fenti gazdanövény nemzetséghez társuló első ismert inquilin fajainak tekinthetjük. Azonban egyelöre gubacsgazda fajaikat sajnos nem sikerült beazonosítanunk. Ugyanezen a fö leszármazási vonalon beül a KeletPalearktikumban és az Orientális régióban élő, eddig még le nem írt Saphonecrus fajokat érintő előzetes filogenetikai és morfológiai vizsgálataink eredményeként egy másik elkülönülő kládot is azonosítottunk, melynek tagjai szintén a Lithocarpus fajokhoz asszociálódtak. Ezen fajok azonban morfológiájuk és vizsgált génszekvenciáik (COI és 28S D2) alapján egyértelműen elkülönülnek az általunk leírt Lithosaphonecrus génusztól.

Az elemzésünkbe bevont Nyugat-Palearktikus fajok harmadik csoportját képviselő „undulatus” ág szintén a harmadik fö leszármazási vonal részét képezte, molekuláris és morfológiai bizonyítékaink alapján nagyon erősen különválik a „barbotini” és „,connatus” vonalaktól. Összhangban a molekuláris filogenetiai eredményekkel, az Ufo nemzetséget is beleértve a harmadik fö leszármazási vonalba sorolható összes többi Saphonecrus klád hordozza az „undulatus” csoport morfológiai sajátosságait és így ezek is eltérnek a „connatus” és „,barbotini” csoportoktól, valamint a Synophrus génusztól.

A Saphonecrus fajoknak az eddig említett három fő leszármazási vonala, valamint a további Saphonecrus kládok olyan sajátos morfológiai karakterállapotokkal rendelkeznek melyek alapján könnyen megkülönböztethető önálló morfológiai egységeket - génuszokat képeznek. Nem kétséges, hogy a Saphonecrus nem jelenlegi határait meg kell változtatni, számos új monofiletikus génuszt kell kialakítani. Az új génuszok felállítása miatt természetesen a 
nevezéktanban is változások várhatóak, illetve a Kelet-Palaearktikus és Orientális Régió (Tajvan) új fajainak leírásával párhuzamosan az új génuszok részletes morfológiai jellemzésére is hamarosan sor kerül. Ezen kívül a Fülöp-szigetekröl ismert két Saphonecrus fajt, valamint néhány, a Nearktikumból ismert Saphonecrus fajt is különálló nemként kell kezelni.

A gazda specifikus differenciáció a fajképződés egyik fontos tényezője lehet a növénynövényevő és a gazda-parazita rendszerekben (Abrahamson és mtsi, 2001; Baer és mtsi, 2004; Forbes és mtsi, 2009). A gubacs különböző jellemzői hatással lehetnek az inkquilin darázs peterakási sikerére. Ilyenek lehetnek például a gubacs külső parenchimájának jellegzetességei (pl. ragacsos vagy pihés felszín), lignifikáció mértéke, vagy a gubacs falvastagsága. Ezekről már ismert, hogy a parazitoidok peterakási sikerét befolyásolhatják (Bailey és mtsi, 2009). A gubacs ezen tulajdonságait a gubacsdarázs kontrollálja (kivétel a Synophrus génusz fajai), és gyakran fajspecifikusak, ami alapján nem zárható ki olyan inkvilin rasszok megjelenése, melyek hasonló típusú gubacsokat részesítenek előnyben. A munkánkban elemzett eddig még leíratlan KeletPalearktikus példányok döntő többségének gubacsdarázs gazdafaja jelenleg még ismeretlen. Ezért vizsgálatunkban megpróbáltunk kapcsolatot találni az elemzett kombinált fajfa topológiája és a gazdagubacsok 4 típusának (levél-, szár-, rügy- és barkagubacs) a génfán megfigyelt eloszlása között. Eredményeink alapján a gubacsok növényen elfoglalt helyzetében, a levélgubacsoknak a leveleken elfoglalt helyzetében és a gubacsok felszíni mintázatában tapasztalt eltérések több esetben alátámasztották a morfológiai- és molekuláris vizsgálatokon alapuló rokonsági viszonyokat, illetve az egyes leszármazási vonalakon belül felállított alcsoportok határait.

Elsősorban a Nyugat-Palearktikus tölgy gubacsdarazsakkal végzett legfrissebb filogenetikai kutatások jelentős különbségeket találtak a különböző tölgyszekciókhoz kötődő gubacsdarázs közösségek között (Cook és mtsi 2002, Ács és mtsi 2007, Stone és mtsi 2009). Valamint az inquilin fajok gazdanövény kapcsolatait vizsgálva - különösképpen a Synerguskomplex esetében - konzervatív evolúciós kapcsolatokat kellett volna tapasztalnunk (Ács és mtsi 2010). Tanulmányunk azonban ezek független radiációját sugallja. Erre a két legszembetűnőbb példa a Lithocarpus nemzetséghez kötődő már említett két leszármazási vonal. A Fagaceae családon belül a Quercus és a Lithocarpus génuszok korai szétválása (Oh és Manos 2008) nem tükröződött a vizsgált inquilin fajok törzsfejlődésében. Továbbá úgy tünik, hogy a Quercus nemzetség Cerris szekciójára specifikus Kelet-Palearktikus Ufo génusz és a Nyugat-Palearktus fajokat magában foglaló „undulatus” klád a Cyclobalanopsis szubgénuszhoz asszociálódott Saphonecrus vonalakhoz kapcsolódik. Véleményünk szerint további kutatásokra van szükség annak érdekében, hogy pontosan felderíthessük a cynipid inquilin leszármazási vonalakon le- 
játszódott gazdanövény váltásokat. 


\section{Summary}

Gall induction has evolved many times among arthropods. Gall wasps (Hymenoptera: Cynipidae) comprise one of the most species-rich and diverse groups of gallers and are special in many ways. All cynipid gall wasps are phytophagous, although they belong to the superfamily Cynipoidae which are mainly endoparasitic insects. Within the Cynipidae, a group of species (comprising the inquiline tribe Synergini) has lost the ability to induce galls, but are obligate inhabitants of galls induced by other species. These herbivorous inquilines are also able to modify the differentiation of plant tissues of galls to form larval chambers within which the larvae feed on highly specialized nutritive plant tissues (Brooks and Shorthouse 1998).

Cynipid galls represent a habitat and food resource for a relatively closed community of arthropods, in which parasitoid, hyperparasitoid and inquiline species may also be found beside the gall inducers. The least known and studied trophic level of the oak gall community is the inquilines. One of the underlying causes may be that the taxonomic identification of Synergini species is difficult and requires a lot of experience. The tribe Synergini includes about 186 species (during our research other four newly described Lithosaphonecrus species were added), of which 48 is present in the Western Palaearctic. A number of important taxonomic and phylogenetic issues remain unresolved for cynipid inquilines, and in order to address them, molecular phylogenetic analyses may be needed besides the morphological re-appraisal of diagnostic species level characters. Previous works on gall wasps have shown that a fragment of the nuclear 28S D2 expansion segment is applicable for species level differentiation, while the mitochondrial cytochrome oxidase I (COI) and cytochrome b (cytb) genes are useful for within species studies.

The inquilines are now believed to represent polyphyletic (or paraphyletic) assemblage, in which species associated with rose cynipids are distinct from those associated with oaks. Molecular phylogenetic evidence suggests that the inquilines are not a monophyletic group, and instead comprise up to 3 distinct evolutionary lineages with independent origins within the Aylacini assemblage: a) rose-associates inquilines in Synophromorpha and Periclistus, b) oakassociated inquilines in Ceroptres, c) oak-associated inquilines in Synergus complex which consist of Synophrus-Saphonecrus-Synergus and the Afrotropical genus Rhoophilus attacking moth-induced galls (Nylander 2004a, Melika 2006, van Noort et al. 2007, Liljeblad et al. 2008). The recent phylogenetic reconstructions within the Synergus complex of species support the monophyly of the large genus Synergus and the smaller Synophrus, while the monophyly of Saphonecrus was rejected (Pénzes et al. 2009, Ács et al. 2010). These results are also supported 
by the new molecular phylogeny which we propose in this thesis.

Our main goals were to establish new phylogetetic relationships within the Synergus complex (Agastoroxenia, Ceroptres, Saphonecrus, Synergus, Synophrus, Ufo and „Saphonecruslike" group), to establish their new taxonomy, and the description of a new genus, (Lithosaphonecrus), with the designation of the type-species and description of four new species. Other aims were to justify the necessity of the phylogetenic analysis of Saphonecrus genus and Saphonecrus-like groups and to reveal host plant and host gall associations of these group of species.

In case of cynipids, nuclear 28S D2 locus and mitochondrial cytochrome oxydase I unit (COI) are frequently used. The 28S D2 locus on generic level and the mitochondrial locus for specific level showing the necessary variability. We chose these markers because than we are able to compare our results with others. The terminology used to describe gall wasp morphology follows other recent cynipid studies (Melika et al. 2010; Liljeblad et al. 2008). Abbreviations for fore wing venation follow Ronquist \& Nordlander (1989), cuticular surface terminology follows that of Harris (1979).

Our molecular analysis recognized three main clades within Saphonecrus and Saphonecrus-like species. The first clade include the,Synophrus+barbotini” species group (Synophrus species and the mediterranean Saphonecrus barbotini and S. gallaepomiformis). Our research supporting the earlier established hypothesis that Saphonecrus gallaepomiformis and S. barbotini together with all known Synophrus species forms a monophyletic group (Pénzes et al. 2009, Ács et al. 2010). According to our results the position of two Saphonecrus species within this clade would be much more comprehensible if they would be erected into a new genus, based on their morphological, biological peculiarities and distributional pattern.

The second main clade is formed by the „connatus” group, which includes Saphonecrus connatus and two other undescribed Eastern Palaearctic species from Russia and Japan, specimens of which were involved into our analysis. The placement of Saphonecrus connatus, the type species of Saphonecrus, is crucial to decide the status of Saphonecrus. Our results demonstrates that the „connatus” lineage is also present in the Eastern Palaearctic (Russia and Japan), supporting its supposed trans-Palaearctic distribution (Sakagami 1949, Abe et al. 2007). This lineage is associated with the white oak section of Quercus. All the molecular data, together with some morphological peculiarities, suggests that it is clearly a distinct unit (genus), different from the „barbotini” clade. It is a separate early lineage within the complex of Saphonecrus species. Furthermore, S. haimi and S. undulatus, known from Quercus section Cerris hosts, may be a western representative of a large eastern radiation on different oak lineages. 
The third lineage which includes all other Saphonecrus species involved into the analysis is divided into further subclades, one of which the Lithosaphonecrus while the other one includes Synergus species. Concerning the monophyly of Synergus, it is important to state that only western and eastern palaearctic Synergus species were included in the analysis, so the worldwide monophyly of Synergus remains to be tested. Many species assigned to Nearctic Synergus differ strongly in morphology from Palaearctic species. Preliminary analysis (results to be published elsewhere) shows at least three distinct morphological and molecular groups within Nearctic Synergus, and full phylogenetic analysis of these groups will significantly alter current interpretation of the genus.

All 334 known species of Lithocarpus are native to east and southeast Asia (Govaerts \& Frodin 1998; Manos et al. 2001). Only two gallwasp species from Taiwan, Cycloneuroterus formosanus Tang \& Melika and Dryocosmus testisimilis Tang \& Melika, are known to induce galls on Lithocarpus (Melika et al. 2011; Tang et al. 2011). No inquilines associate with cynipid gallwasps develop on Lithocarpus species were yet described. Herein described new genus, Lithosaphonecrus, with four species, L. formosanus, L. dakengi, L. huisuni and L. yunnani, based on their morphological peculiarities and molecular data (mitochondrial COI and nuclear 28S D2 genes) forms a distinct monophyletic group and thus a distinct genus within the Saphonecrus-like species in the Eastern Palaearctic.These are the first inquilines known to associate with gallwasps on Lithocarpus.

The „undulatus” lineage is very distant from „barbotini” and „connatus” clades, not only on the basis of molecular evidence but also morphologically. The „undulatus” lineage possess a number of synapomorphies: the shape of the head and its sculpturing; the presence of a strong lateral propodeal carina; the absence of notauli; very short mesoscutum; and others. The three mentioned main Saphonecrus lineages and also subclades within Saphonecrus group\#3 possess some peculiar morphological character states on the basis of which they can be also easily distinguished and form distinct morphological units (genera). There is no doubt that the current limits of the Saphonecrus genus must be changed, and a number of new monophyletic genera must be established. Nomenclatorial changes with the erection of new genera and detailed morphological diagnoses, with the description of new species from the Eastern Palaearctic and the Oriental Region (Taiwan) will be published elsewhere. The two known Saphonecrus species from Philippines, as well as some of the Nearctic Saphonecrus species, must also be consigned to separate and novel genera.

The host-specific differentiation might be one of the main factors of the species formation in the plant-phytophage and host-parasitoid systems (Abrahamson et al. 2001, Baer et al. 2004, 
Forbes et al. 2009). Gall peculiarities influence inquiline's egg laying success. It might be the peculiarities of the gall parenchyma surface (e.g. stickness, hairness), level of lignifications or the gall outer wall thickness. It is already known that those peculiarities influence the egg laying success in parasitoids (Bailey et al. 2009). The gallwasp control these gall peculiarities (except Synophrus species) which are often species specific and thus, it cannot be excluded that such inquiline populations will evolve which prefer galls with the same peculiarities. The majority of host gallwasps mentioned in our work are undescribed Eastern Palaearctic species. Thus in our research we tried to establish a connection between the analyzed combined species-tree topology and 4 types of host galls (leaf, twig, bud and catkin galls) and analyse how those gall types spread on the tree. In many cases, our morphology and molecular based results support the relationship between different clades (subclades) and the position of galls on the leaves and within the plant and the surface of the gall.

Recent analyses primarily of Western Palaearctic oak gall wasps have revealed a deep phylogenetic divide between gall wasp taxa galling different oak sections (Cook et al. 2002, Ács et al. 2007, Stone et al. 2009). A deep evolutionary split was supposed to be present in host plant associations of inquilines, particularly those of the Synergus-complex (Ács et al. 2010). However, our study suggests independent radiations. The most striking example is provided by the two Saphonecrus lineages present on Lithocarpus (Lithosaphonecrus genus and Saphonecrus\#2 lineage). The early split within the Fagaceae between Quercus and Lithocarpus (Oh and Manos 2008) is not reflected in the inquiline phylogeny. Furthermore, the section Cerris-specific and eastern taxon Ufo and the western "undulatus- haimi" clade seem to be associated with clades characteristic to the subgenus Cyclobalanopsis of Quercus. Further research is needed to clarify host switching events in cynipid inquilines. 
10. Függelék 


\begin{tabular}{|c|c|c|}
\hline Fajnév & Elte rje dés & $\begin{array}{l}\text { Növény- és } \\
\text { gubacsgazda }\end{array}$ \\
\hline S. areolatus Weld, 1926 & O: Fülöp-szigetek, Luzon & ismeretlen \\
\hline $\begin{array}{l}\text { S. barbotini Pujade-Villar \& Nieves-Aldrey, } \\
1985\end{array}$ & WP: Ibériai-félsziget & Quercus sect. Cerris \\
\hline S. brevicornis (Ashmead, 1896) & NA: California & ismeretlen \\
\hline S. brevis Weld, 1926 & NA: USA, Arizona, Új-Mexikó & Quercus sect. Quercus \\
\hline S. chaodongzhui Melika, Ács \& Bechtold, 2004 & EP: Kína, Yunnan & ismeretlen \\
\hline S. connatus (Hartig, 1840) & WP: Európa & Quercus sect. Quercus \\
\hline S. diversus Belizin, 1968 & EP: Oroszország, Primorskij Kraj & ismeretlen \\
\hline S. excisus (Kieffer, 1904) & EP: Bengália, Kurseong & Lithocarpus elegans \\
\hline S. favanus Weld, 1944 & NA: DC és Missouri & Quercus sect. Lobatae \\
\hline S. flavitibilis Wang \& Chen, 2010 & EP: Kína, Zhejiang & ismeretlen \\
\hline S. gemmariae Ashmead, 1885 & NA: USA, Florida & Quercus sect. Lobatae \\
\hline S. haimi (Mayr, 1872) & WP: Európa, Észak-Afrika & Quercus sect. Cerris \\
\hline S. hupingshanensis Liu, Yang \& Zhu, 2012 & EP/O: Kína, Hunan & Castanopsis carlesii \\
\hline S. irani Melika \& Pujade-Villar, 2006 & WP: Irán & Quercus sect. Cerris \\
\hline $\begin{array}{l}\text { S. gallaepomiformis (Boyer de Fonscolombe, } \\
\text { 1832)* }\end{array}$ & WP: Ibériai-félsziget & Quercus sect. Cerris \\
\hline S. naiquanlini Melika, Ács \& Bechtold, 2004 & EP: Kína, Zhejiang & ismeretlen \\
\hline S. serratus Weld, 1926 & O: Fülöp-szigetek, Luzon & ismeretlen \\
\hline S. shirakashii (Shinji, 1940) & EP: Japán & $\begin{array}{l}\text { Quercus subgenus } \\
\text { Cyclobalanopsis }\end{array}$ \\
\hline S. shirokashicola (Shinji, 1941) & EP: Japán & $\begin{array}{l}\text { Quercus subgenus } \\
\text { Cyclobalanopsis }\end{array}$ \\
\hline S. sinicus Belizin, 1968 & EP: Kína, Sichuan & ismeretlen \\
\hline S. tianmushanus Wang \& Chen, 2010 & EP: Kína, Zhejiang & ismeretlen \\
\hline S. undulatus (Mayr, 1872) & WP: Európa & Quercus sect. Cerris \\
\hline S. yukawai Wachi, Ide \& Abe, 2011 & EP: Japán & Quercus sect. Cerris \\
\hline
\end{tabular}

Összesen: 23 faj

* korábban az összes szakirodalomban Saphonecrus lusitanicus (Tavares, 1902)-ként említették ezt a fajt. Pujade-Villar a típusok felülvizsgálata után (2004) elvégezte a szükséges változtatásokat a nomenklatúrán és javaslatára a továbbiakb a Saphonecrus gallaepomiformis nevet használják.

I. táblázat: A Saphonecrus génusz ismert fajainak elterjedése és gazda szervezetei. Rövidítések: $\mathrm{EP}=$ Kelet-Palearktikum, $\mathrm{OR}=$ Orientális régió. 


\begin{tabular}{|c|c|c|c|c|}
\hline Taxon/minta neve & AN 28SD2 & AN coxl & Elterjedés & Hivatkozás \\
\hline Saphonecrus sp. 2 (JP02) & JX468368 & JX468362 & KP: Tajvan & Melika és mtsi 2012 \\
\hline $\begin{array}{l}\text { Lithosaphonecrus dakengi Tang \& } \\
\text { Pujade-Villar, } 2013 \text { (sp.4) }\end{array}$ & KC899801 & KC899797 & KP: Tajvan & Bozsó és mtsi 2014 \\
\hline $\begin{array}{l}\text { Ufo cerroneuroteri Tang \& Melika, } \\
2012 \text { (sp.8) }\end{array}$ & JX468367 & JX468357 & KP: Tajvan & Melika és mtsi 2012 \\
\hline Saphonecrus sp. 9 (JP02) & JX468368 & JX468363 & KP: Tajvan & Melika és mtsi 2012 \\
\hline Saphonecrus sp.11 & KF532092 & KF532105 & KP: Tajvan & Bozsó és mtsi 2014 \\
\hline $\begin{array}{l}\text { Lithosaphonecrus huisuni Tang, } \\
\text { Bozsó \& Melika, } 2013 \text { (sp.13) }\end{array}$ & KC899799 & KC899795 & KP: Tajvan & Bozsó és mtsi 2014 \\
\hline $\begin{array}{l}\text { Ufo cerroneuroteri Tang \& Melika, } \\
2012 \text { (sp. 14) }\end{array}$ & JX468367 & JX468358 & KP: Tajvan & Melika és mtsi 2012 \\
\hline Saphonecrus sp.15 & KF532100 & KF532106 & KP: Tajvan & Bozsó és mtsi 2014 \\
\hline Saphonecrus sp. 18 & KF532094 & KF532107 & KP: Tajvan & Bozsó és mtsi 2014 \\
\hline Saphonecrus sp. 21 & JX468369 & JX468364 & KP: Tajvan & Melika és mtsi 2012 \\
\hline Saphonecrus sp. 23 & KF532095 & KF532108 & KP: Tajvan & Bozsó és mtsi 2014 \\
\hline Saphonecrus sp. 25 & KF532096 & - & KP: Tajvan & Bozsó és mtsi 2014 \\
\hline Saphonecrus sp. 27 & KF532091 & KF532121 & KP: Tajvan & Melika és mtsi 2012 \\
\hline $\begin{array}{l}\text { Lithosaphonecrus formosanus } \\
\text { Melika \& Tang, } 2013 \text { (sp. 29) }\end{array}$ & KC899802 & KC899798 & KP: Tajvan & Bozsó és mtsi 2014 \\
\hline Saphonecrus sp. 30 & KF532097 & KF532109 & KP: Kína & Bozsó és mtsi 2014 \\
\hline $\begin{array}{l}\text { Lithosaphonecrus yunnani Tang, } \\
\text { Bozsó \& Melika, } 2013 \text { (sp. 31) }\end{array}$ & KC899800 & KC899796 & KP: Kína & Bozsó és mtsi 2014 \\
\hline Saphonecrus sp. 32 & KF532098 & KF532110 & KP: Tajvan & Bozsó és mtsi 2014 \\
\hline Saphonecrus sp. 34 & KF532099 & KF532111 & KP: Tajvan & Bozsó és mtsi 2014 \\
\hline Saphonecrus sp. 35 & KF532095 & KF532112 & KP: Tajvan & Bozsó és mtsi 2014 \\
\hline Saphonecrus sp. 36 & KF532100 & KF532113 & KP: Tajvan & Bozsó és mtsi 2014 \\
\hline $\begin{array}{l}\text { Ufo nipponicus Melika, } 2012 \text { (sp. } \\
\text { 38) }\end{array}$ & JX468367 & JX468359 & KP: Japán & Melika és mtsi 2012 \\
\hline $\begin{array}{l}\text { Ufo nipponicus Melika, } 2012 \text { (sp. } \\
\text { 39) }\end{array}$ & JX468367 & JX468360 & KP: Japán & Melika és mtsi 2012 \\
\hline $\begin{array}{l}\text { Ufo nipponicus Melika, } 2012 \text { (sp. } \\
\text { 40) }\end{array}$ & JX468367 & JX468361 & KP: Japán & Melika és mtsi 2012 \\
\hline $\begin{array}{l}\text { Saphonecrus shirokashicola (Shinji } \\
\text { 1941) (sp.44) (JP03) }\end{array}$ & JX468371 & JX468366 & KP: Japán & Melika és mtsi 2012 \\
\hline
\end{tabular}

II. táblázat: A molekuláris filogenetikai analízisben felhasznált Saphonecrus, Synergus és Synophrus egyedek adatai. A “AN 28S D2" és "AN coxI” oszlopokban az új és a letöltött szekvnciák GenBank azonosítóját adtuk meg. A saját adatainkat vastag betüvel kiemeltem. 


\begin{tabular}{|c|c|c|c|c|}
\hline Taxon/minta neve & AN 28SD2 & AN coxI & Elterjedés & Hivatkozás \\
\hline Saphonecrus sp. 46 & KF532101 & KF532114 & KP: Tajvan & Bozsó és mtsi 2014 \\
\hline Saphonecrus sp. 48 & KF532102 & KF532115 & KP: Tajvan & Bozsó és mtsi 2014 \\
\hline Saphonecrus sp. 49 & KF532092 & KF532116 & KP: Tajvan & Bozsó és mtsi 2014 \\
\hline Saphonecrus sp. 50 & KF532103 & KF532117 & $\begin{array}{c}\text { KP: } \\
\text { Oroszország }\end{array}$ & Bozsó és mtsi 2014 \\
\hline Saphonecrus sp. 51 & KF532103 & KF532118 & KP: Japán & Bozsó és mtsi 2014 \\
\hline Saphonecrus sp. 56 & KF532101 & KF532119 & KP: Tajvan & Bozsó és mtsi 2014 \\
\hline $\begin{array}{l}\text { Saphonecrus shirokashicola (Shinji } \\
\text { 1941) (sp.57)(JP03) }\end{array}$ & JX468371 & KF532121 & KP: Japán & Melika és mtsi 2012 \\
\hline Saphonecrus sp. 58 & KF532104 & KF532120 & KP: Tajvan & Bozsó és mtsi 2014 \\
\hline $\begin{array}{l}\text { Saphonecrus shirakashii (Shinji, } \\
\text { 1940) (JP01) }\end{array}$ & JX468370 & JX468365 & KP: Tajvan & Melika és mtsi 2012 \\
\hline $\begin{array}{l}\text { Saphonecrus barbotini Pujade-Villar } \\
\text { \& Nieves-Aldrey, } 1985\end{array}$ & EF487124 & EF486877 & $\begin{array}{l}\text { NYP: Ibériai- } \\
\text { félsziget }\end{array}$ & Ács és mtsi 2010 \\
\hline Saphonecrus connatus (Hartig, 1840) & EF487125 & EF486878 & NYP: Európa & Ács és mtsi 2010 \\
\hline $\begin{array}{l}\text { Saphonecrus gallaepomiformis (Boyer } \\
\text { de Fonscolombe, 1832) }\end{array}$ & EF487131 & EF486881 & $\begin{array}{l}\text { NYP: Ibériai- } \\
\text { félsziget }\end{array}$ & Ács és mtsi 2010 \\
\hline Saphonecrus haimi (Mayr, 1872) & EF487126 & EF486879 & $\begin{array}{l}\text { NYP: Európa, } \\
\text { Észak-Afrika }\end{array}$ & Ács és mtsi 2010 \\
\hline $\begin{array}{l}\text { Saphonecrus irani Melika \& Pujade- } \\
\text { Villar, } 2006\end{array}$ & EF487127 & - & NYP: Irán & Ács és mtsi 2010 \\
\hline Saphonecrus undulatus (Mayr, 1872) & EF487133 & EF486883 & NYP: Európa & Ács és mtsi 2010 \\
\hline $\begin{array}{l}\text { Synergus chinensis Melika, Ács \& } \\
\text { Bechtold, } 2004\end{array}$ & EF487140 & EF486890 & $\begin{array}{l}\text { KP: Kína, } \\
\text { Korea }\end{array}$ & Ács és mtsi 2010 \\
\hline $\begin{array}{l}\text { Synergus consobrinus Giraud in } \\
\text { Houard, } 1911\end{array}$ & EF487189 & EF486954 & $\begin{array}{l}\text { NYP: Ausztria, } \\
\text { Magyarország }\end{array}$ & Ács és mtsi 2010 \\
\hline Synergus crassicornis (Curtis, 1838) & EF487147 & EF486898 & $\begin{array}{l}\text { NYP teljes } \\
\text { területe }\end{array}$ & Ács és mtsi 2010 \\
\hline Synergus flavipes Hartig, 1843 & EF487151 & EF486903 & $\begin{array}{l}\text { WP: Austria, } \\
\text { Hungary }\end{array}$ & Ács és mtsi 2010 \\
\hline Synergus japonicus Walker, 1874 & EF487167 & EF486927 & $\begin{array}{l}\text { KP: Japán, } \\
\text { Korea }\end{array}$ & Ács és mtsi 2010 \\
\hline $\begin{array}{l}\text { Synergus mikoi Melika \& Pujade- } \\
\text { Villar, } 2006\end{array}$ & EF487169 & EF486928 & NYP: Irán & Ács és mtsi 2010 \\
\hline Synergus physocerus Hartig, 1843 & EF487185 & EF486950 & $\begin{array}{l}\text { NYP teljes } \\
\text { területe }\end{array}$ & Ács és mtsi 2010 \\
\hline
\end{tabular}

II. táblázat (folytatás): A molekuláris filogenetikai analízisben felhasznált Saphonecrus, Synergus és Synophrus egyedek adatai. A "AN 28S D2" és "AN coxI" oszlopokban az új és a letöltött szekvenciák GenBank azonosítóját adtuk meg. A saját adatainkat vastag betủvel kiemeltem. 


\begin{tabular}{|c|c|c|c|c|}
\hline Taxon/minta neve & AN 28SD2 & AN coxI & Elterjedés & Hivatkozás \\
\hline $\begin{array}{l}\text { Synergus plagiotrochi Nieves-Aldrey \& } \\
\text { Pujade-Villar, } 1986\end{array}$ & EF487187 & EF486952 & \multirow{2}{*}{$\begin{array}{l}\text { Spanyolország } \\
\text {, } \\
\text { Franciaország } \\
\text { NYP teljes } \\
\text { területe }\end{array}$} & Ács és mtsi 2010 \\
\hline $\begin{array}{l}\text { Synergus thaumacerus (Dalman, } \\
\text { 1823) }\end{array}$ & EF487191 & EF486956 & & Ács és mtsi 2010 \\
\hline $\begin{array}{l}\text { Synergus xiaolongmeni Melika, Ács } \\
\text { \& Bechtold, } 2004\end{array}$ & EF487220 & EF486968 & KP: Kína & Ács és mtsi 2010 \\
\hline Synergus variabilis Mayr, 1872 & EF487219 & EF486967 & NYP: Európa & Ács és mtsi 2010 \\
\hline Synophrus olivieri Kieffer, 1898 & EF583959 & EF579725 & $\begin{array}{l}\text { NYP: Észak- } \\
\text { Afrika, Irán, } \\
\text { Kaukázus }\end{array}$ & Ács és mtsi 2010 \\
\hline Synophrus pilulae Houard, 1911 & EF487224 & EF579716 & $\begin{array}{l}\text { NYP: Ausztria, } \\
\text { Magyarország }\end{array}$ & Ács és mtsi 2010 \\
\hline Synophrus politus Hartig, 1843 & EF487223 & EF579710 & $\begin{array}{l}\text { NYP: Európa, } \\
\text { Törökország, } \\
\text { Jordánia }\end{array}$ & Ács és mtsi 2010 \\
\hline Ceroptres clavicornis Hartig, 1840 & EF487120 & EF486871 & $\begin{array}{l}\text { NYP teljes } \\
\text { területe }\end{array}$ & Ács és mtsi 2010 \\
\hline Rhoophilus loewi Mayr, 1881 & EF487123 & EF486876 & E: Dél-Afrika & Ács és mtsi 2010 \\
\hline
\end{tabular}

II. táblázat (folytatás): A molekuláris filogenetikai analízisben felhasznált Saphonecrus, Synergus és Synophrus egyedek adatai. A "AN 28S D2" és "AN coxI" oszlopokban az új és a letöltött szekvenciák GenBank azonosítóját adtuk meg. A saját adatainkat vastag betűvel kiemelt 